\title{
Multi-Seam Well Completion Technology: Implications for Powder River Basin Coalbed Methane Production
}

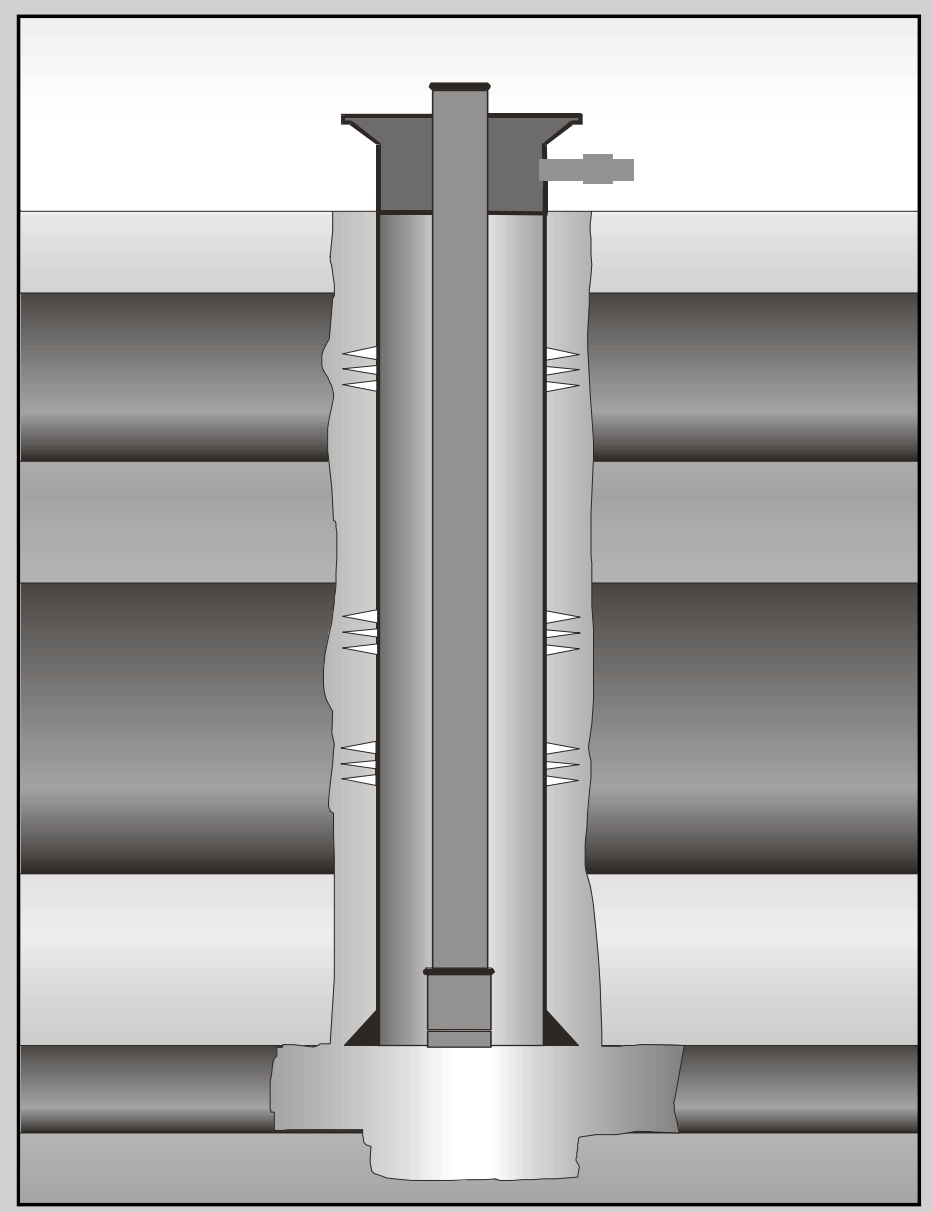

\section{U.S. Department of Energy}

\section{Office of Fossil Energy}

$$
\text { and }
$$

National Energy Technology Laboratory Strategic Center for Natural Gas 


\title{
Multi-Seam Well Completion Technology: Implications for Powder River Basin \\ Coalbed Methane Production
}

\author{
U.S. Department of Energy \\ National Energy Technology Laboratory (NETL) \\ (Strategic Center for Natural Gas)
}

DOE/NETL-2003/1193

September 2003 


\section{DISCLAIMER}

This report was prepared as an account of work sponsored by an agency of the United States Government. Neither the United States Government nor any agency thereof, nor any of their employees, makes any warranty, express or implied, or assumes any legal liability or responsibility for the accuracy, completeness, or usefulness of any information, apparatus, product, or process disclosed, or represents that its use would not infringe privately owned rights. Reference therein to any specific commercial product, process, or service by trade name, trademark, manufacturer, or otherwise does not necessarily constitute or imply its endorsement, recommendation, or favoring by the United States Government or any agency thereof. The views and opinions of authors expressed therein do not necessarily state or reflect those of the United States Government or any agency thereof. 


\section{TECHNICAL PREFACE}

Coalbed methane (CBM) production is a substantial component of U.S. domestic natural gas supply. The San Juan and Warrior Basins are widely recognized areas of CBM development. In the last several years, however, the Powder River Basin has evolved as the most active natural gas play in the United States. More than 13,000 wells have been drilled in the basin. Moreover, there is the potential for drilling up to 76,000 total wells in the basin to fully develop its CBM resources.

Resource development has primarily occurred along the eastern margin of the basin where the coals are relatively shallow and thick, and drilling costs are low. Because of these attributes, it is common practice to drill a production well into each seam to drain the gas. Generally, thin seams (i.e., less than $20 \mathrm{ft}$.) are bypassed in favor of developing the gas resource in much thicker coals. Completing multiple zones (coal seams) in a single wellbore is routine practice throughout industry; however, early attempts at multi-seam completions (MSC) in the Powder River Basin have met with mixed and limited success. This lack of success and the desire to explore potentially more efficient methods of developing CBM in the basin provided the impetus to assess the impacts of MSC.

The 'Impacts of MSC' study is a natural outgrowth of an earlier Department of Energy (DOE) analysis of CBM resource development in the Powder River Basin entitled, Powder River Basin Coalbed Methane Development and Produced Water Management Study. Consistent with this initial study, our current analysis was conducted at a township level. As with all assessments conducted at such a broad level, readers must recognize and understand the limitations and appropriate use of the results. Raw and derived data provided in this report will not generally apply to any specific location. Water influx was not modeled, although it is acknowledged that this phenomenon may occur in some settings.

Notwithstanding the drilling of $13,000+$ wells, large areas of the basin remain relatively undeveloped, which introduces additional uncertainty and increases variability. Proxies and analogs were used in the analysis as necessary and appropriate. New data and interpretations, which have become available since completion of DOE's initial evaluation ${ }^{1}$ have been incorporated into this analysis. Continued development in the basin will obviously make additional data and interpretations available, which will lead to a more 
complete description of the coals and their fluid flow properties, and refined estimates of natural gas and water production rates and cumulative recoveries.

As with any resource development evaluation, technical and economic results are the product of the assumptions and methodology used. This analysis assumes that MSC technology becomes effective and is adopted basin-wide by producers, and permitted by states. As such, study results reflect a limiting case (i.e., a maximum benefit) scenario. Economic results are before-federal-income-tax (BFIT). It is recognized that natural gas prices are volatile and may not be consistent with the price modeled. The price and basis differentials modeled however, were representative at the time of study initiation. Users of the data, information, and results of this evaluation must consider them wisely within the context of their own operations and planning scenarios. Finally, inherent to this analysis, is that, along with the increase in CBM production, the additional volumes of produced water could be appropriately managed.

For more information about DOE exploration and production technology projects visit the National Energy Technology Laboratory website at www.netl.doe.gov, or the Office of Fossil Energy website at www.fe.doe.gov/programs oilgas.html. Inquiries specific to coalbed methane topics should be directed to Peter Lagiovane at: 202-586-8116. 


\section{TABLE OF CONTENTS}

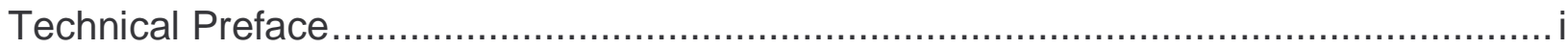

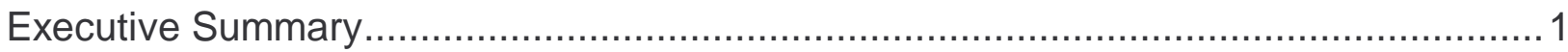

SECTION 1. STUDY PURPOSE, APPROACH, AND FINDINGS …..........................

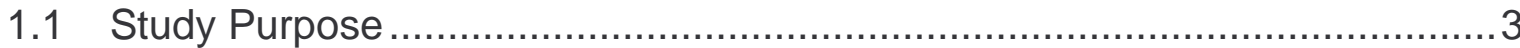

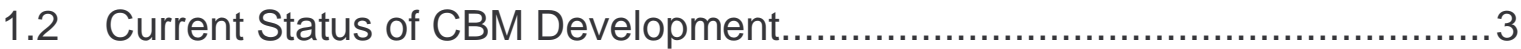

1.3 Study Approach and Methodology ………….......................................10

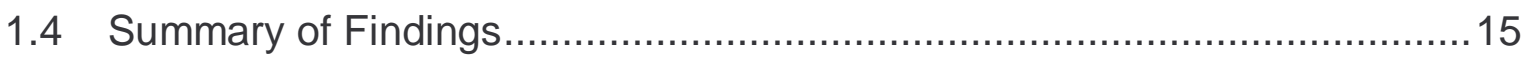

SECTION 2. STUDY APPROACH AND METHODOLOGY..........................................25

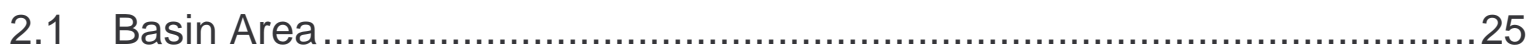

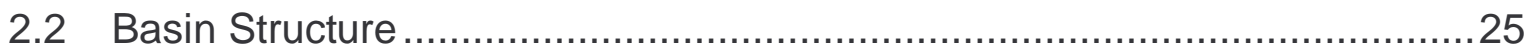

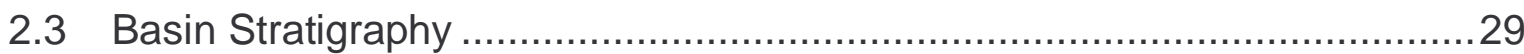

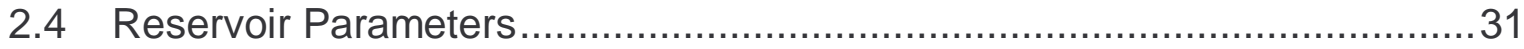

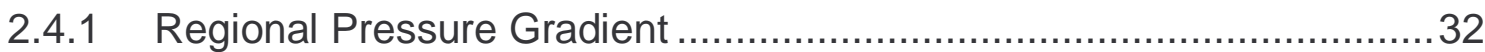

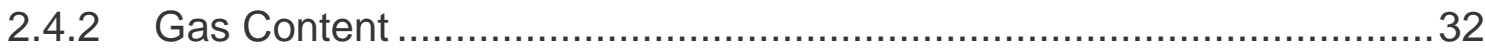

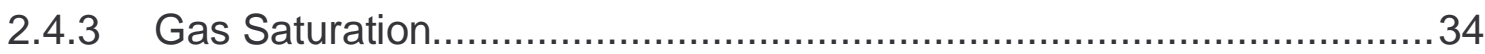

2.4.4 Coal Fracture and Matrix Porosity …….............................................35

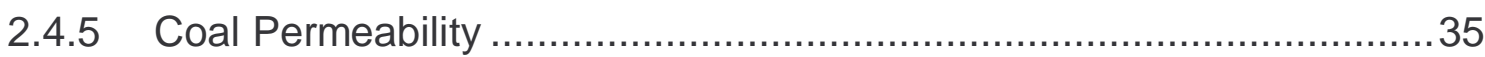

2.4.6 Estimating Gas and Water Production................................................35

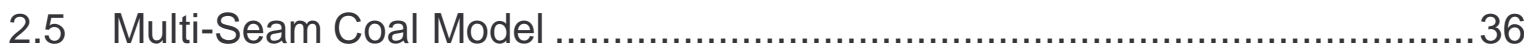

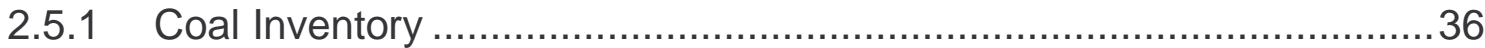

2.5.2 Coal Packages and Completion Criteria.............................................38

2.5.3 Volumetric CBM Database ......................................................... 41

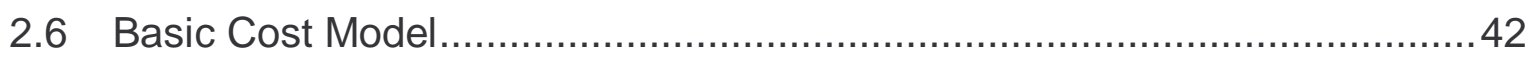

2.6.1 Capital Costs for PRB CBM Well ................................................. 42

2.6.2 Operating \& Maintenance Costs for PRB CBM Well ...........................45 
2.6.3 Gas Transportation, Compression, and Fuel Use ............................45

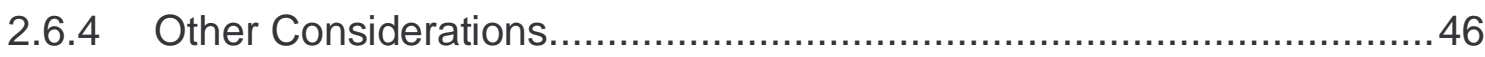

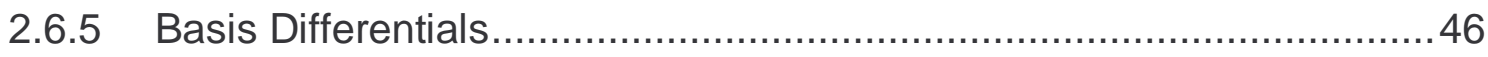

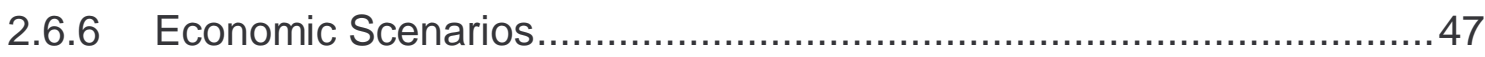

SECTION 3. PERFORMANCE OF MULTI-SEAM CBM WELL COMPLETIONS

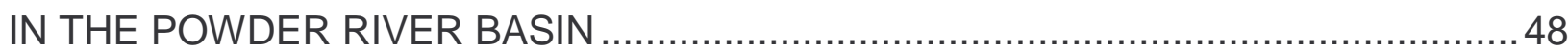

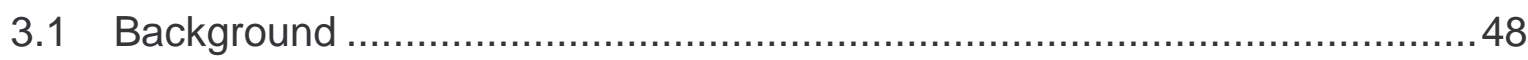

3.2 Overview of CBM Well Completions ....................................................... 48

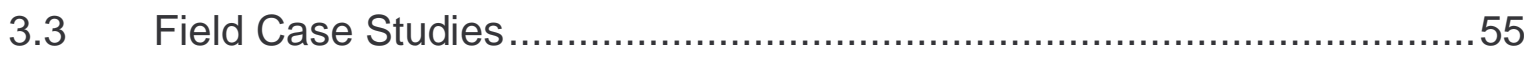

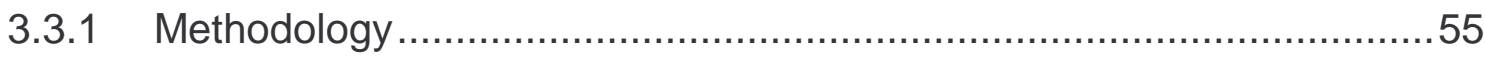

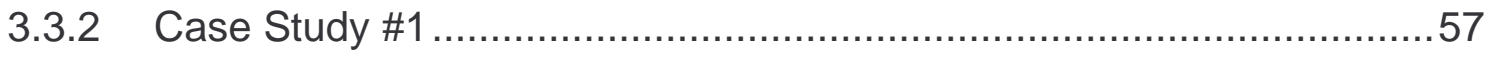

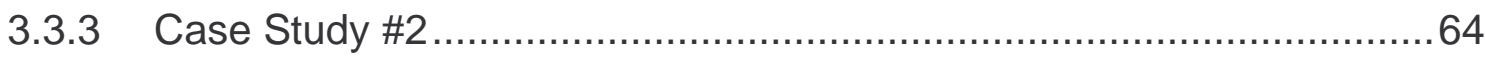

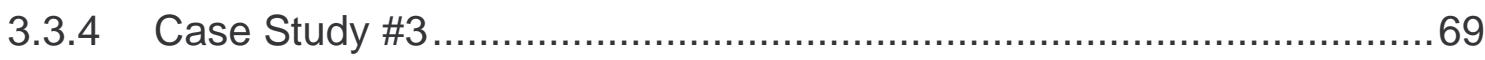

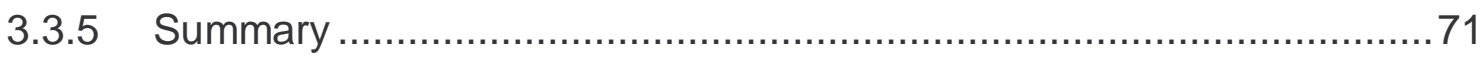

SECTION 4. APPLICATION AND PERFORMANCE OF MULTI-SEAM COMPLETION TECHNOLOGY IN OTHER CBM BASINS ..................................... 73

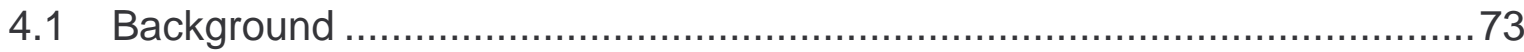

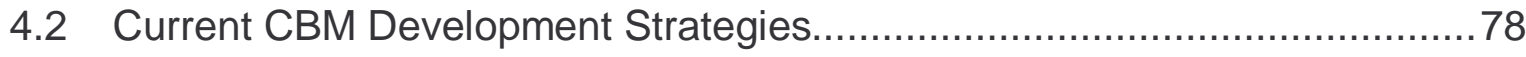

4.3 Testing Multi-Seam Well Completion Technology in the Warrior Basin ........79

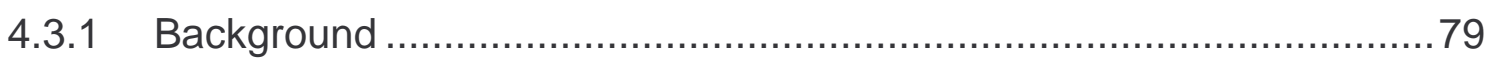

4.3.2 Multi-Seam Completion Analysis .................................................. 80

SECTION 5. BENEFITS OF MULTI-SEAM COMPLETION TECHNOLOGY

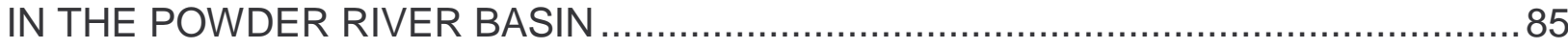

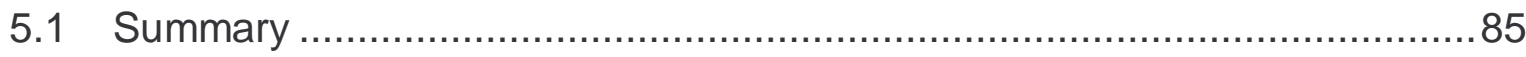

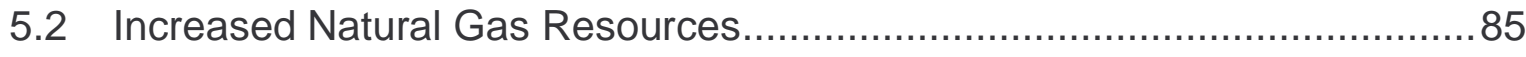

5.3 Larger Economically Recoverable Resource..........................................89

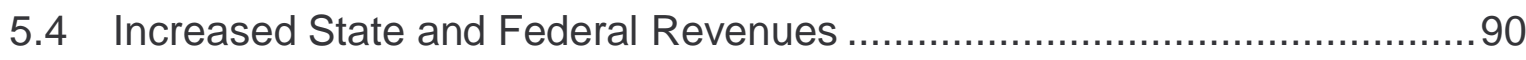




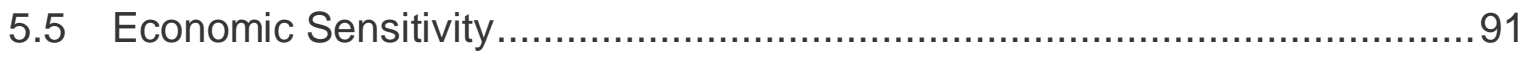

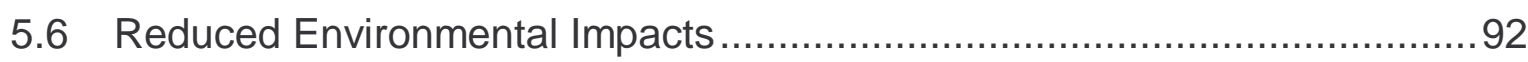

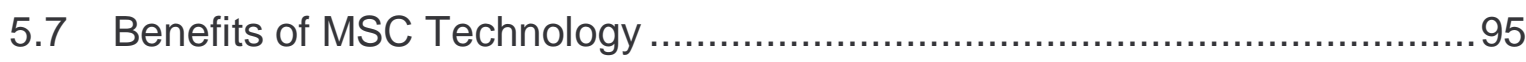

5.8 Detailed Benefits of Using MSC Technology ...........................................

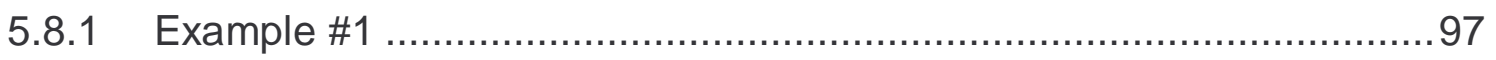

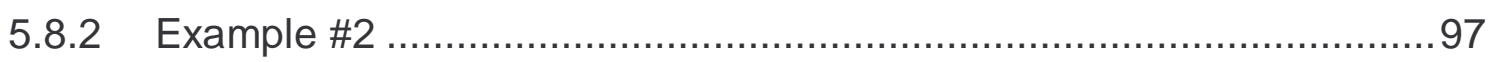

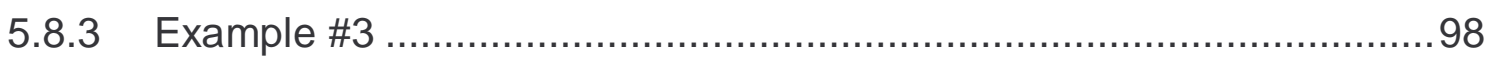

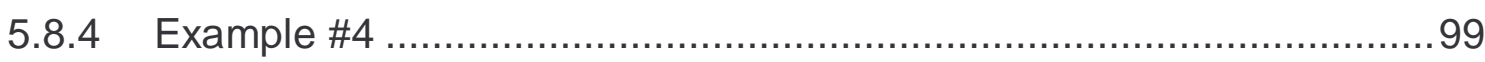

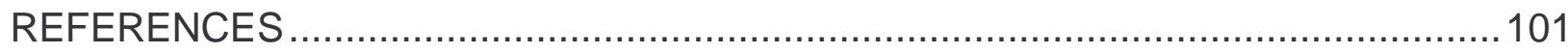

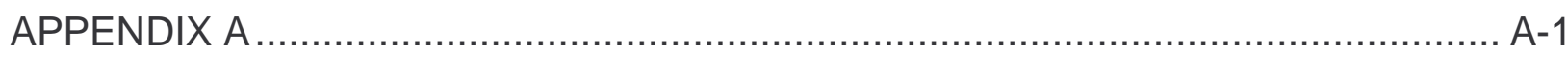

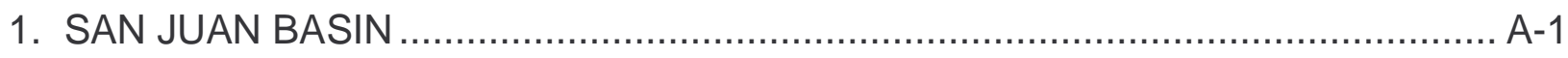

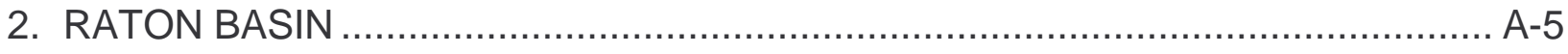

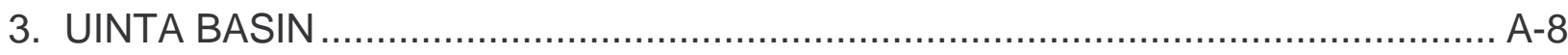




\section{LIST OF TABLES}

Table 1-1. Multi-Seam Example \#1 - Marginally Economic Thick Coal

Seam is Completed with Thin Seams to Make an

Economic CBM Well

Table 1-2. Royalty and Severance/Ad Valorem Tax Receipts Under Two

Technology Options

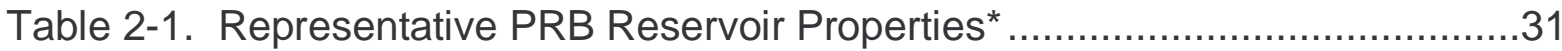

Table 2-2. Capital Costs for Illustrative CBM Well, Powder River Basin.

Table 3-1. Average Case Study \#1 Single-Seam Canyon Well and Multi-Seam Canyon/Cook/Wall Well, After 12 and 18 Months of Production

Table 3-2. Average Case Study \#2 - Single-Seam and Multi-Seam Wells, 8 Months of Production

Table 3-3 Average Case Study \#3 - Single-Seam and Multi-Seam Recompleted Wells

Table 5-1. Coal and Coalbed Methane Resources of the Powder River Basin, by Basin Partition

Table 5-2. Economically Recoverable CBM by Mineral Ownership .89

Table 5-3. State and Federal Revenues From CBM Development in the Powder River Basin.

Table 5-4. Economically Recoverable CBM Resources for Scenarios \#1 and \#2

Table 5-5. Number of Wells Required to Produce CBM Resources in the PRB, Two Alternative Well Completion Technologies 95

Table 5-6. Distribution of Economic CBM Resources Under Scenario \#1 ...............96

Table 5-7. Distribution of Economic CBM Resources Under Scenario \#2 ...............96

Table 5-8. Multi-Seam Example \#1 - Marginally Economic Thick Coal Seam Is Completed with Thin Seams to Make an Economic CBM Well

Table 5-9. Multi-Seam Example \#2 - Thin Seams Are Completed with an Economic Thick Coal Seam to Increase Well Reserves 98

Table 5-10. Multi-Seam Example \#3-Multiple Economic Coal Seams Are Completed in a Single Well to Reduce Capital Expenditures and Surface Disturbance.

Table 5-11. Multi-Seam Example \#4 - An Uneconomic Township Is Made Economic Using MSC Technology.... 


\section{LIST OF FIGURES}

Figure 1-1. Outline and Location of Powder River Basin .......................................5

Figure 1-2. End-of-Year CBM Production Rate for Powder River Basin

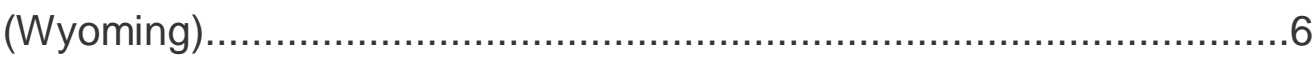

Figure 1-3. End-of-Year Producing CBM Wells for Powder River Basin

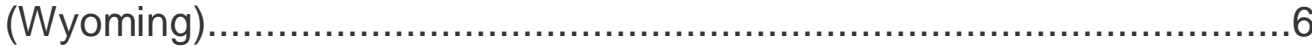

Figure 1-4. Areas of Coalbed Methane Development, Powder River Basin ..............7

Figure 1-5. E-W Cross-Section Showing Splitting of the Thick Wyodak Coal Seam into Thinner Units...................................................................9

Figure 1-6. Basin Map Submitted to WYOGCC by CBM Operator in Northern PRB, Suggesting Need for Effective Multi-Seam

Completions 12

Figure 1-7. Townships with CBM Well Logs Analyzed for this Report....................13

Figure 1-8. Gas Content Isotherm Used for Powder River CBM MSC Technology.14

Figure 1-9. Average Synthesized Adsorption Isotherm for Coals in the Powder River Basin...............................................................14

Figure 1-10. Gas-in-Place and Technically Recoverable CBM Resource, Powder River Basin.

Figure 1-11. Economically Recoverable CBM Resources using MSC; Two Economic Scenarios, Powder River Basin.

Figure 1-12. Economically Recoverable CBM Using Multi-Seam (MSC) and Single Seam (SS) Technology, Powder River Basin.

Figure 1-13. Areas with an Abundance of Thin Seams Requiring Multi-Seam Completion Technology for Economic Development, Powder River Basin. 22

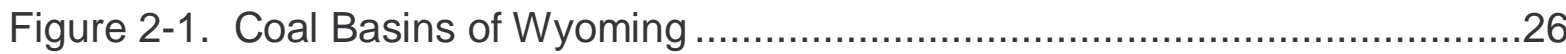

Figure 2-2. Regional Structure and Tectonic Map of the Powder River Basin ........27

Figure 2-3. Regional Cross-Section of the Powder River Basin ...........................28

Figure 2-4. Upper Cretaceous and Tertiary Stratigraphic Chart for Powder River Basin. .28

Figure 2-5. Coal-Bearing Units of the Tongue River Member of the Fort Union Formation 30

Figure 2-6. Reservoir Pressure Profile Used for PRB Study ................................33

Figure 2-7. Gas Content Isotherm Used for MSC Study ....................................33

Figure 2-8. Average Synthesized Adsorption Isotherm for Coals in the Powder River Basin .34

Figure 2-9. Wyodak Coal Seam Time Zero Plot 37 
Figure 2-10. Wyodak Type Well History Match .38

Figure 2-11. Map Showing Townships from which a CBM Well Log Was Analyzed for this Report. .40

Figure 2-12. PRB Coal Database for 24 Townships in Partition \#8, Northeast Powder River Basin

Figure 2-13. Natural Gas and Water Production (as modeled) for One Township in Partition \#8 Northeast Powder River Basin 44

Figure 3-1. Typical CBM Well Completion Practice, Powder River Basin.................50

Figure 3-2. Single-Seam Coalbed Methane Well, Powder River Basin ...................50

Figure 3-3. Well Log Showing Typical Fort Union Stratigraphy ...........................51

Figure 3-4. Map Submitted by Powder River Basin Operator(s) Showing Areas Where MSC Technology is Vital for Future

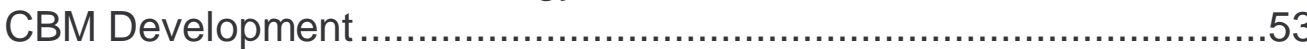

Figure 3-5. Multi-Seam Completion Option 1 .................................................5

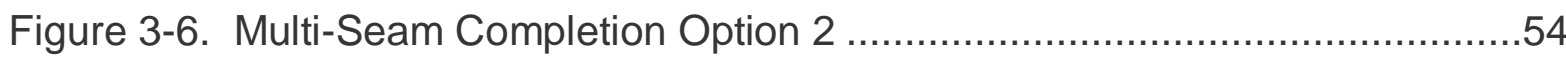

Figure 3-7. Location Map for Multi-Seam Case Studies .....................................56

Figure 3-8. Location of Yates CBM Wells Included in Case Study \#1 .....................58

Figure 3-9. Case Study \#1 Single-Seam Well ......................................................59

Figure 3-10. Case Study \#1 Multi-Seam Well.................................................62

Figure 3-11. Time-Zero Production Rate for Average Single-Seam Canyon Well and Average Multi-Seam Canyon-Cook-Wall Well ........63

Figure 3-12. Time-Zero Cumulative Production for Average Single-Seam Canyon Well and Average Multi-Seam Canyon-Cook-Wall Well.... .63

Figure 3-13. Time-Zero Water Production Rate for Average Single-Seam Canyon Well and Average Multi-Seam Canyon-Cook-Wall Well 64

Figure 3-14. Location of Huber CBM Wells Included in Case Study \#2...................65

Figure 3-15. Production Rate for Average Single-Seam Wells (Cook, Wall) and Average Multi-Seam Wells (Canyon-Cook-Wall, Canyon-Cook-Wall-Pawnee).

Figure 3-16. Cumulative Production for Average Single-Seam Wells (Cook, Wall) and Average Multi-Seam Wells (Canyon-Cook-Wall, Canyon-Cook-Wall-Pawnee). .68

Figure 3-17. Water Production Rate for Average Single-Seam Wells (Cook, Wall) and Average Multi-Seam Wells (Canyon-Cook-Wall,

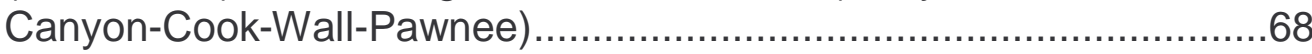

Figure 3-18. Location of Majestic CBM Wells Included in Case Study \#3 ................71 
Figure 3-19. Average Case Study \#3 Canyon CBM Well and its Recompletion......72

Figure 4-1. Location of the Rock Creek Field Research Site, Warrior Basin, Alabama

Figure 4-2. Effect of Multiple Completion of Coal Seams on Breakeven

Gas Price, Warrior Basin, Alabama .................................................75

Figure 4-3. Objectives of Multi-Seam Completion Project .......................................76

Figure 4-4. Multiple Completion Potential of Pennsylvanian Age Coals ..................77

Figure 4-5. Percentage Distribution of Abraded Perforation Sets within Treatment Intervals, Hendrix Study Area Wells ........................81

Figure 4-6. Downhold Camera Observations at the Soterra 9-7 \#1 Well.................82

Figure 4-7. Downhole Camera Observations, Oak Grove \#681 Study Well ............84

Figure 5-1. Gas-in-Place and Technically Recoverable CBM Resource,

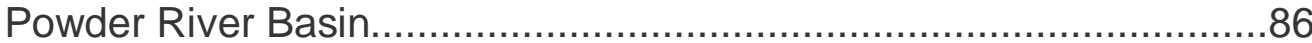

Figure 5-2. Powder River Basin CBM Partitions (MSC Study) ..............................88

Figure 5-3. Economically Recoverable CBM Resources, Two Economic Scenarios, Powder River Basin...................................................93

Figure 5-4. Impact of MSC Technology on Economically Recoverable CBM Resources from the Powder River Basin, Two Scenarios

Figure A-1. Cased Hole Completion, Single-Stage Stimulation, San Juan Basin CBM Well

Figure A-2. Open-Hole Completion, Dynamic Cavitation, San Juan Basin CBM Well A-4

Figure A-3. Cased Hole Completion, Multiple-Stage, Small Interval Stimulation, Raton Basin CBM Well

Figure A-4. Cased Hole Completion, Multiple-Stage Large Interval Stimulation, Uinta Basin CBM Well 


\section{EXECUTIVE SUMMARY}

The President's National Energy Policy (NEP) Report estimates that over the next 20 years annual natural gas consumption in the United States will increase by 50 percent to nearly 35 trillion cubic feet (Tcf). A contemporary forecast ${ }^{1}$ fully supports this demand increase, though with a short delay. To meet this growing demand for natural gas, the NEP report concludes that we will have to fully develop, in an environmentally sensitive manner, our nation's economically recoverable natural gas resources.

Natural gas produced from coal seams, commonly referred to as coalbed methane (CBM), constitutes 7.5 percent of total annual domestic natural gas production, or 1.6 trillion cubic feet in 2001. The Powder River Basin, located in northeastern Wyoming and southeastern Montana, is the nation's fastest growing source of coalbed methane. At the end of 2002, nearly 1 billion cubic feet of gas per day was being produced out of the basin from 10,800 wells. Over the next 10 or more years, natural gas development in the Powder River Basin is expected to increase dramatically. In the Wyoming portion of the basin, as many as 39,000 additional wells might be drilled, with the majority of these wells being located on federal lands.

Recognizing the natural gas potential of the basin, as well as the associated resource development issues, the U.S. Department of Energy (DOE), Office of Fossil Energy, through its National Energy Technology Laboratory, contracted with Advanced Resources International, Inc. (ARI) to analyze the basin's geology and underlying coalbed methane resources. In a study released in November 2002 entitled, Powder River Basin Coal Bed Methane Development and Produced Water Management Study, DOE determined that the Powder River Basin contains a considerably larger quantity of natural gas resources than previously estimated, but

\footnotetext{
${ }^{1}$ Energy Information Administration. Annual Energy Outlook 2003 with Projections to 2025. DOE/EIA-0383(2003).
} 
that development of the basin's coalbed methane resources will be significantly impacted by the costs, i.e., economic feasibility, of produced water management practices and requirements.

This study builds on the earlier analysis of the basin. ${ }^{2}$ Current results indicate that using multi-seam completion (MSC) technology to access the numerous sequences of thin coal seams (less than 20 feet thick) would substantial increase the volume of recoverable gas and significantly improve the economics of CBM development in the basin.

The technically recoverable coalbed methane resource in the Powder River Basin is now estimated to be 50 trillion cubic feet-assuming widespread, successful use of MSC technology. Moreover, substituting MSC technology for the currently used single-seam well completions would raise the estimate of economically recoverable CBM from the basin by $21 \mathrm{Tcf}$. Significant financial benefits will also accrue to many levels of government, as well as to private mineral royalty owners. In fact, state severance and ad valorem tax collections are estimated to increase by up to $\$ 3.6$ billion, with royalty payments to federal and state governments expected to increase by up to $\$ 4.1$ billion.

CBM operators in the Powder River Basin have attempted to implement MSC techniques that have been developed and utilized in other coalbed methane plays. Results to date, however, have generally been disappointing, due to the challenges arising from the geologic and reservoir conditions unique to the Powder River Basin-shallow, underpresssured, low-rank (low strength) coals surrounded by water-bearing aquifers. Clearly, study results provide a basis for further review of alternative well completion practices, and a possible technology development/ demonstration effort to more efficiently develop the natural gas locked within the region's vast coal resources.

2 U.S. DOE. Powder River Basin Coalbed Methane Development and Produced Water Management Study. DOE/NETL-2003/1184. 


\section{SECTION 1. STUDY PURPOSE, APPROACH, AND FINDINGS}

\subsection{Study Purpose}

The purpose of this study is to evaluate the potential benefits of applying multiseam [well] completion (MSC) technology to the massive stack of low-rank coals in the Powder River Basin. As part of this, the study objectives are:

- Estimate how much additional CBM resource would become accessible and technically recoverable - compared to the current practice of drilling one well to drain a single coal seam;

- Determine whether there are economic benefits associated with MSC technology utilization (assuming its widespread, successful application) and if so, quantify the gains;

- Briefly examine why past attempts by Powder River Basin CBM operators to use MSC technology have been relatively unsuccessful;

- Provide the underpinnings to a decision whether a MSC technology development and/or demonstration effort is warranted by DOE.

To a great extent, this assessment builds on the previously published study (DOE, 2002), which contains many of the key references that underlie this analysis. It is available on the U.S. Department of Energy, National Energy technology Laboratory, Strategic Center for Natural Gas website (www.netl.doe.gov/scng). It is suggested that readers obtain a copy of the original study to complement the current report.

\subsection{Current Status of CBM Development}

The Powder River Basin CBM play is located in northeastern Wyoming and southeastern Montana (Figure 1-1). Covering 12,000 square miles, the CBM play encompasses parts of seven counties in two states, and targets methane contained in the tertiary-age Fort Union Formation coal seams. Depths for the play range from 
300 feet to over 3,000 feet, and include a series of distinct coal seams, such as the Anderson, Wyodak and Big George.

Although the basin's potential as a large CBM resource was recognized more than two decades ago, its low-rank coals discouraged development. By the mid1990s however, the potential of the Powder River Basin CBM play was better understood and activity surged. Over the past five years, development has increased dramatically. During 2000, coalbed methane production and the number of producing wells more than doubled. Growth in 2001 was nearly as strong. At the end of 2002, the CBM play was producing nearly 1 Bcf per day from 10,800 producing wells (Figures 1-2 and 1-3).

Within the basin, CBM development is spreading westward, toward the deeper basin center from coal outcrops on the eastern edge of the basin. Another focus of development is in the Tongue River area on the western side of the basin, along the Wyoming-Montana border (Figure 1-4).

In spite of its large resource potential, numerous barriers exist that may delay or even halt the timely development of coalbed methane in the Powder River Basin. Recent trends already point to a slowdown in growth for this important domestic natural gas play. The reasons for the slowdown are many. Oil and natural gas development in the Powder River Basin suffers from inaccessibility to major markets, resulting in a high basis differential. In addition, limited outlets and access to hubs for this basin lead to relatively high gas-gathering costs. Issuance of permits, litigation, and surface use issues also impact resource development efforts in the basin. 


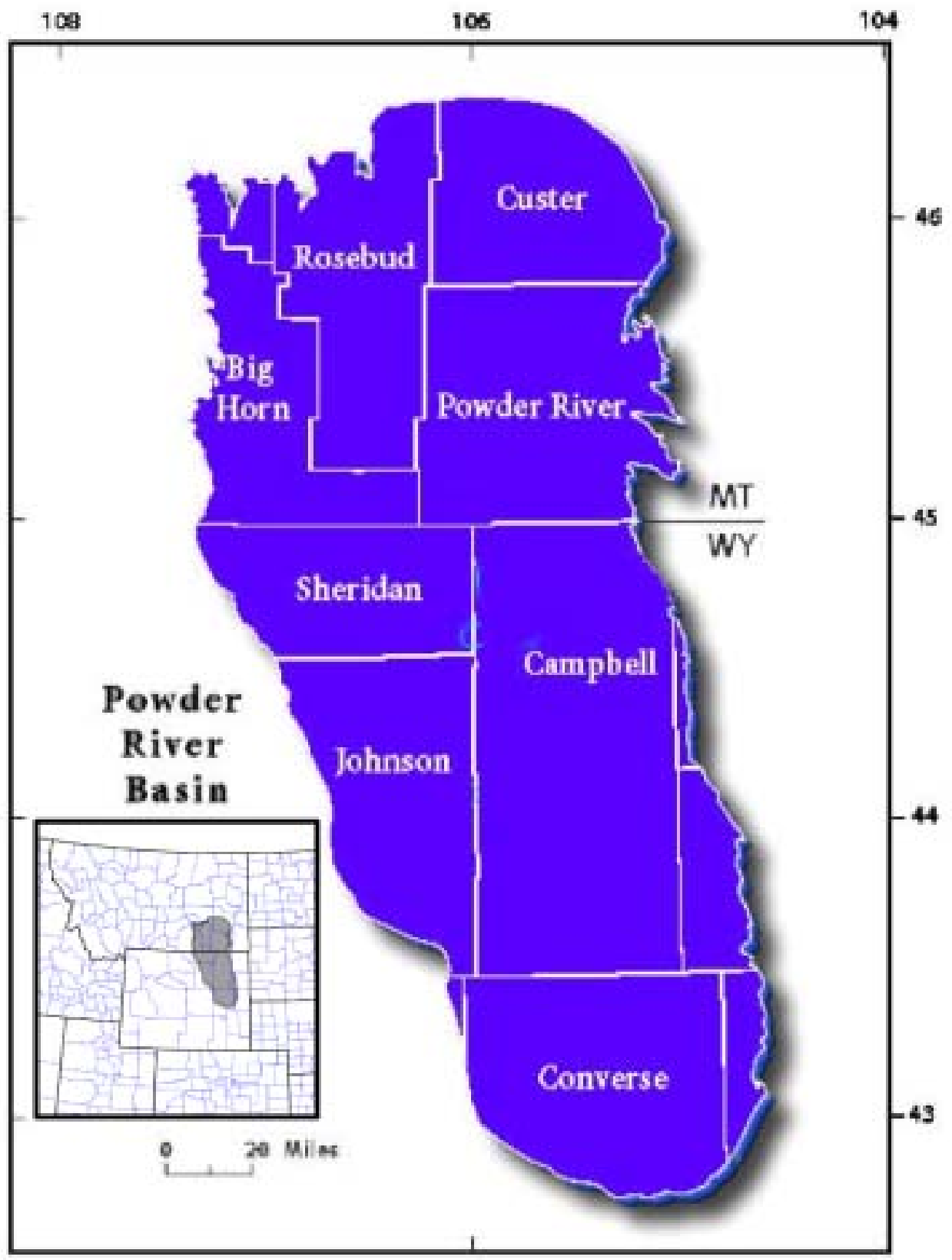

Figure 1-1. Outline and Location of Powder River Basin. 


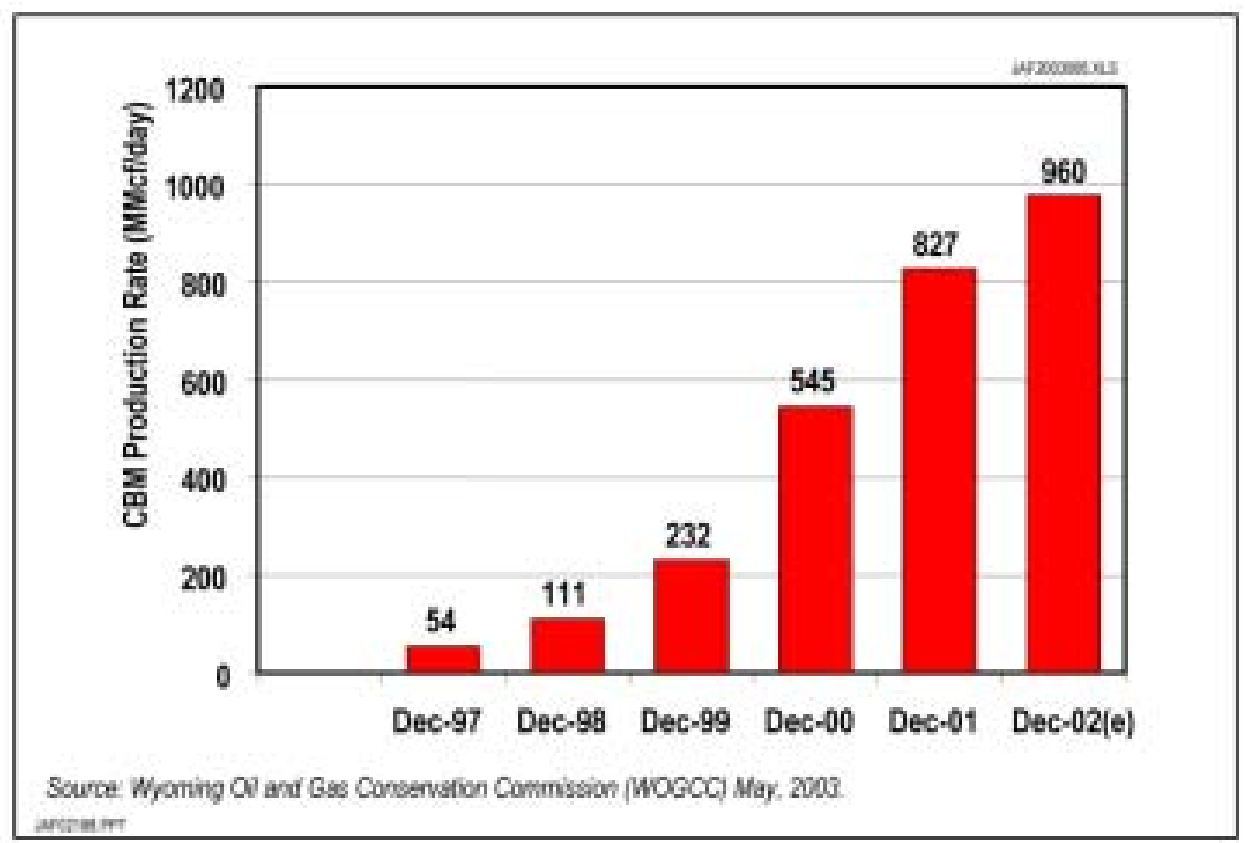

Figure 1-2. End-of-Year CBM Production Rate for Powder River Basin (Wyoming).

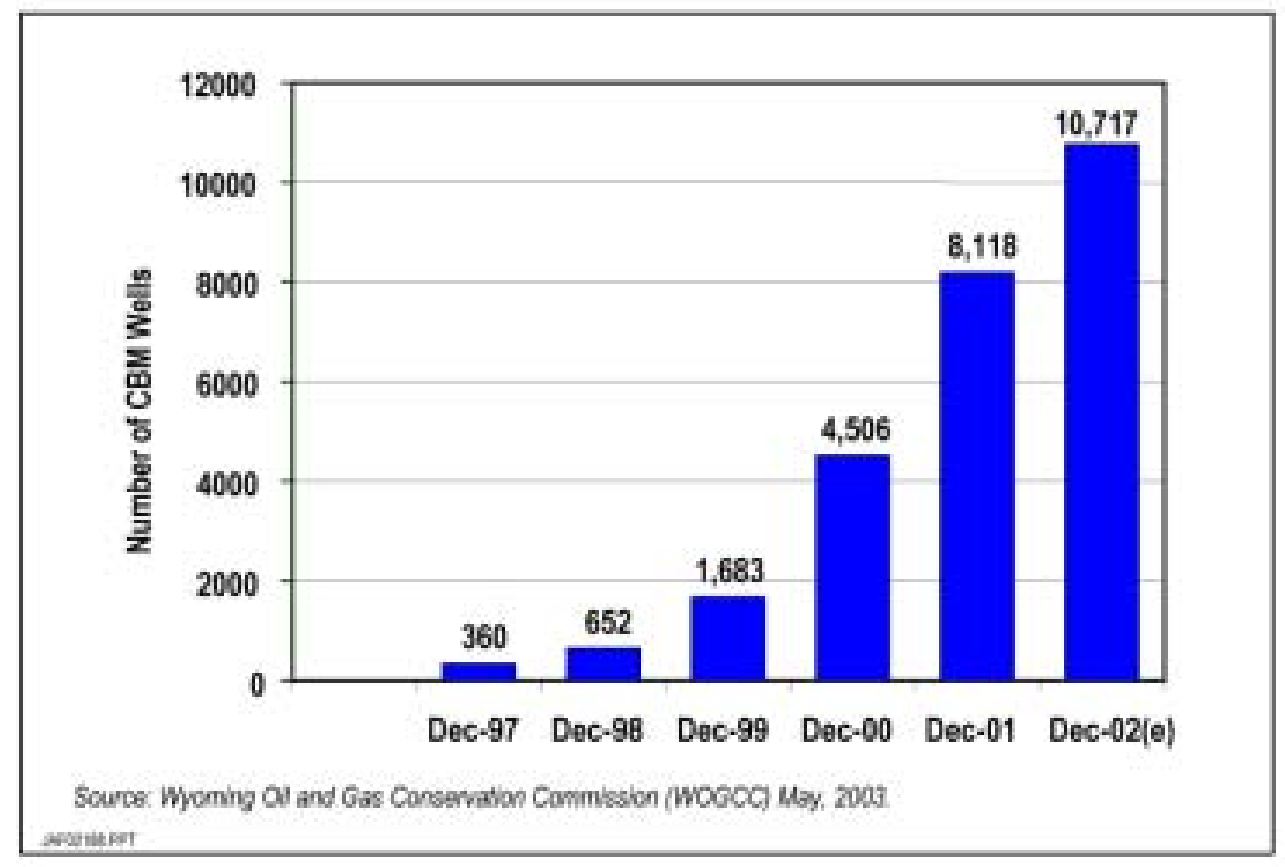

Figure 1-3. End-of-Year Producing CBM Wells for Powder River Basin (Wyoming). 


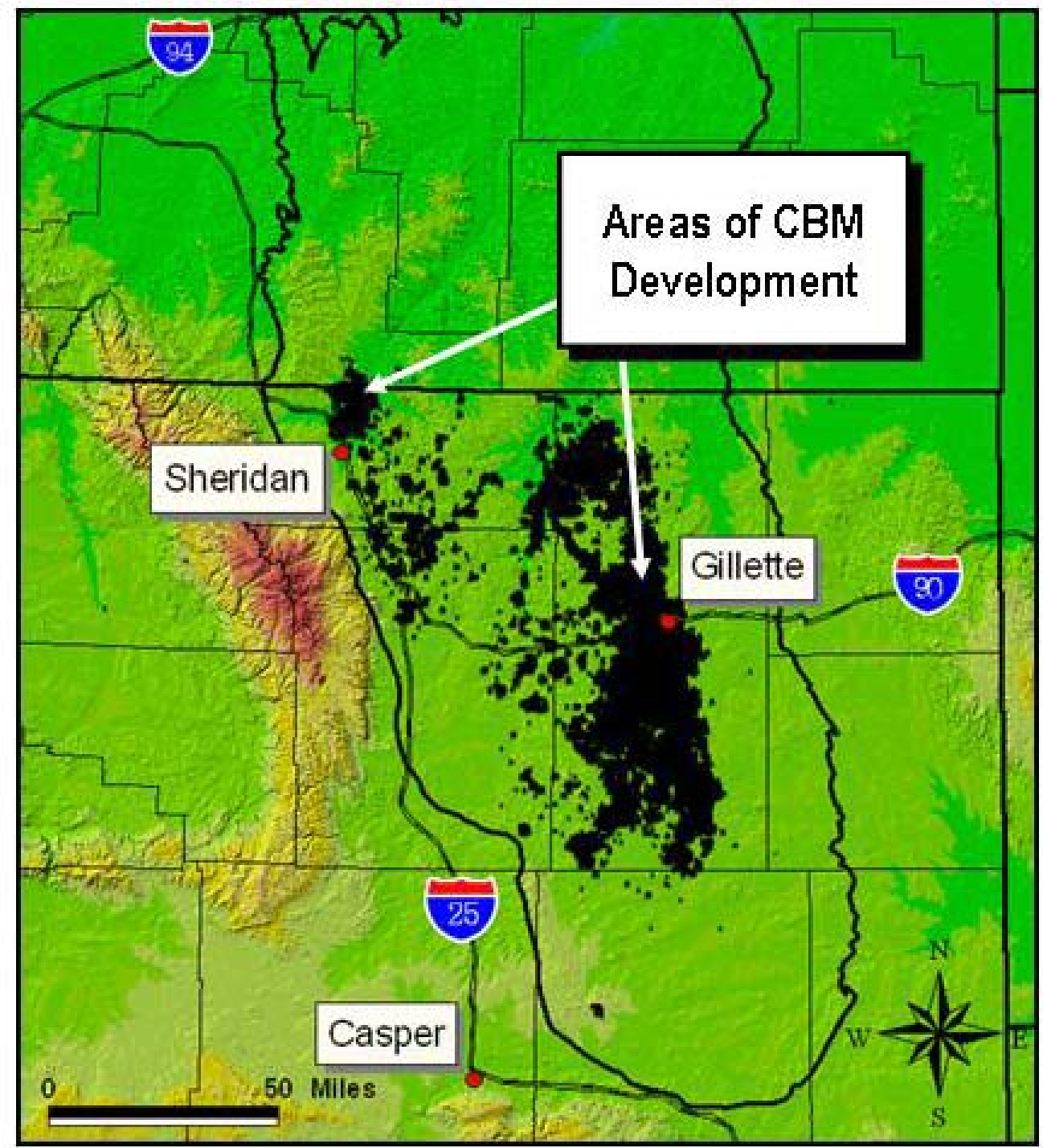

Figure 1-4. Areas of Coalbed Methane Development, Powder River Basin. 
So far, the low costs of drilling the shallow, thick, easy-to-reach coal seams along the eastern edge of the basin have been able to offset these economic barriers. With the depletion of the geologically more favorable areas, development has moved toward the deeper and thinner coals in the central and northern portions of the basin, (Figure 1-5). Here, currently used single-seam well completion technology, which bypasses the thinner coal seams, may no longer be adequate.

Management of produced CBM water in the Powder River Basin poses another barrier that has been a most visible topic of late. In the arid west, water is a valuable resource and, as such, its prudent management is important. Significant volumes of water must be pumped from a coal seam to depressurize the coal and allow gas desorption to begin. While much of the CBM water in the Powder River meets US EPA guidelines for irrigation, stock watering, and even human consumption, some areas do not. These areas will have to consider higher cost water management options such as reinjection, impoundment, or active treatment.

These issues, left unaddressed, could limit the development of the Powder River Basin CBM play. Economic improvements, such as lower basis differentials and gathering costs that would provide a higher netback wellhead price would help, but a more comprehensive approach is required.

One of the most promising means for improving the future outlook for coalbed methane in this basin is to develop/adapt alternative well completion technology, appropriate for linking multiple coal seams (including thin seams) with a single well. Under current practices, a CBM well targets a single thick coal seam (at least 20 feet in thickness) and bypasses the thinner seams, because a thinner seam by itself simply does not contain enough gas to make an economic well. In areas of the basin with thick shallow coals, this completion approach has, for the most part, been effective. As CBM development progresses across the remainder of the basin, this approach may no longer suffice. However, if several thinner coal seams could be completed by a single well, CBM reserves would be significantly increased, while adding little to drilling and completion costs. 


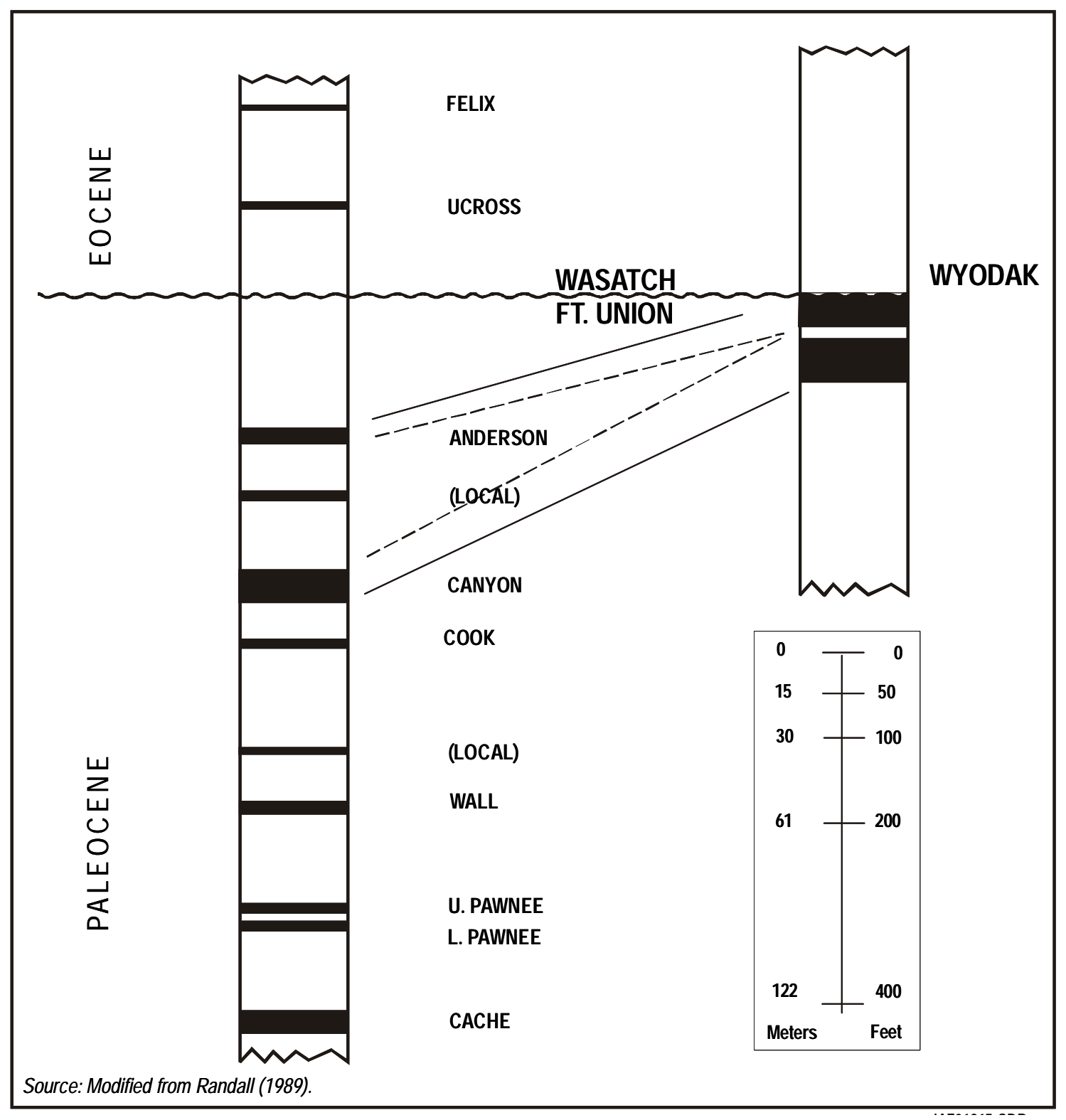

Figure 1-5. E-W Cross-Section Showing Splitting of the Thick Wyodak Coal Seam into Thinner Units. 
CBM operators in the Powder River Basin have long recognized the potential utility of multi-seam completion technology. Several operators have highlighted areas where such technology would be advantageous or vital for further development, as shown on Figure 1-6. Unfortunately, because of the unique geological and reservoir properties of Powder River Basin coals, the application of MSC technology transferred from other CBM basins has been relatively unsuccessful. Details of these unsuccessful attempts to produce natural gas simultaneously from multiple coals are discussed in more detail in Section 3.

\subsection{Study Approach and Methodology}

To better define the potential of multi-seam well completion technology, and at the request of the Department of Energy, Advanced Resources International (ARI) undertook the following work to assess coalbed methane resource and technology in the Powder River Basin:

1. Created an up-to-date, township-level database for all coal seams in the Powder River Basin. This involved:

- Analyzing over 270 new well logs from the Powder River Basin (PRB) CBM play area (Figure 1-7);

- Tabulating thin coals with thicknesses of 5 to 10 feet and 10 to 20 feet, by depth, stratigraphic interval, and basin area; and

- Correlating the newly defined thin coal seams with ARl's existing PRB thick greater than 20 feet) coal seams database.

2. Established packages of multiple coal seams, including thin and thick seams, for development by a single well with multi-seam completion technology.

3. Developed an updated gas content and methane adsorption isotherm specific to the Powder River Basin based on more recent gas content and isotherm data, as shown in Figure 1-8. For comparison purposes, Figure 1-9 shows 
the range of gas content versus pressure values assembled from past coal samples collected in the PRB.

1. Applied seam-by-seam coal reservoir properties and history matched "type wells" (developed in the previous Powder River Basin study) for:

- Estimating CBM production and ultimate recovery per well ${ }^{1}$, and

- Estimating water production and ultimate recovery per well ${ }^{1}$.

Collected detailed cost data on multi-seam well completions from vendors and producers, incorporated these data to update ARl's existing Powder River cost model, and employed ARl's economic model as follows:

- Used a long-term \$3.50/Mcf (flat) price track at the Henry Hub,

- Included costs of applying MSC technology for completing up to four coal zones per well, consistent with practices in other CBM basins,

- Modified certain water management infrastructure costs, and

- Used two distinct basis differential cases.

1. Estimates include areas already under development. 


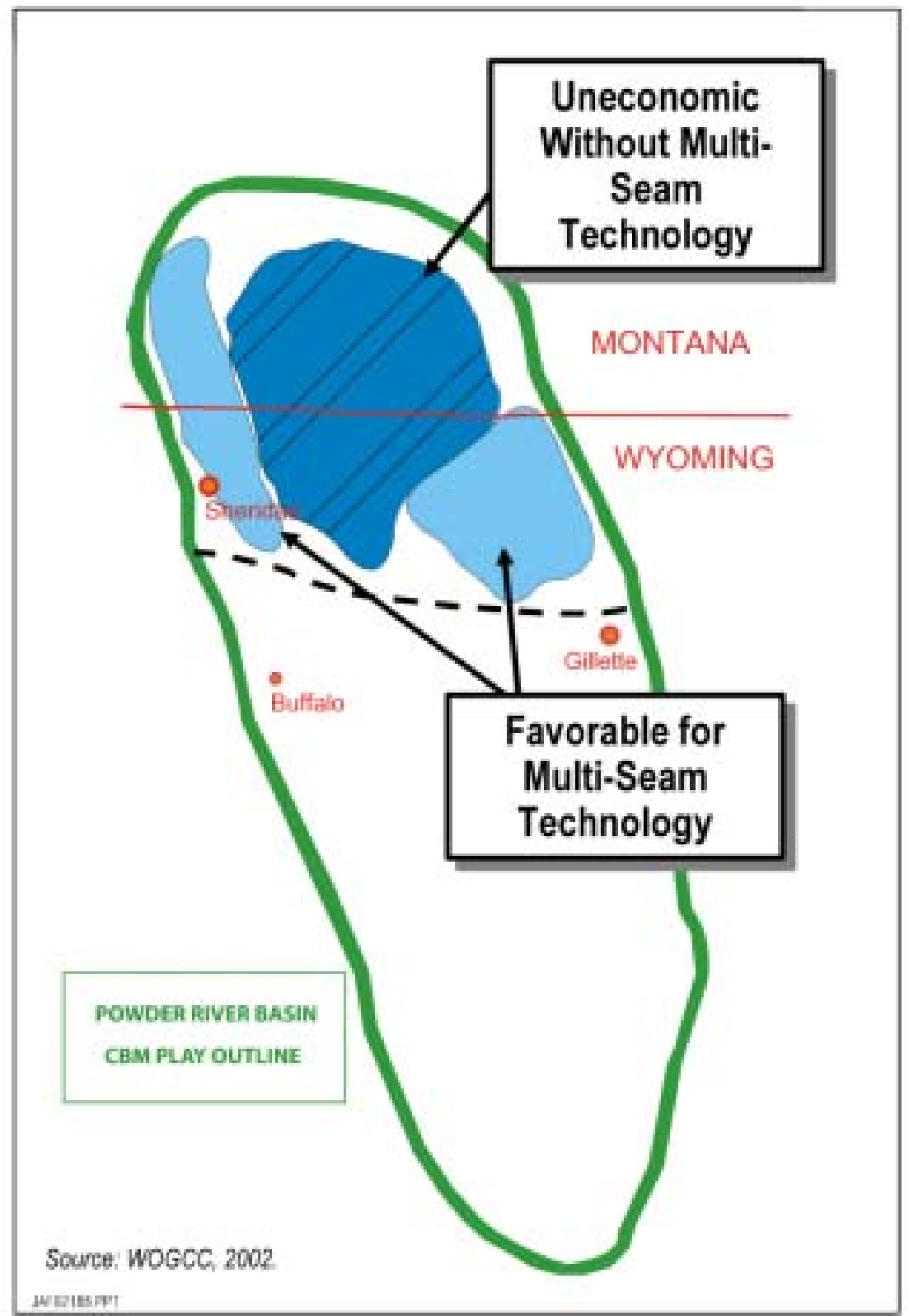

Figure 1-6. Basin Map Submitted to WYOGCC by CBM Operator in Northern PRB, Suggesting Need for Effective Multi-Seam Completions.

Few logs exist in Montana and the western edge of the play. 


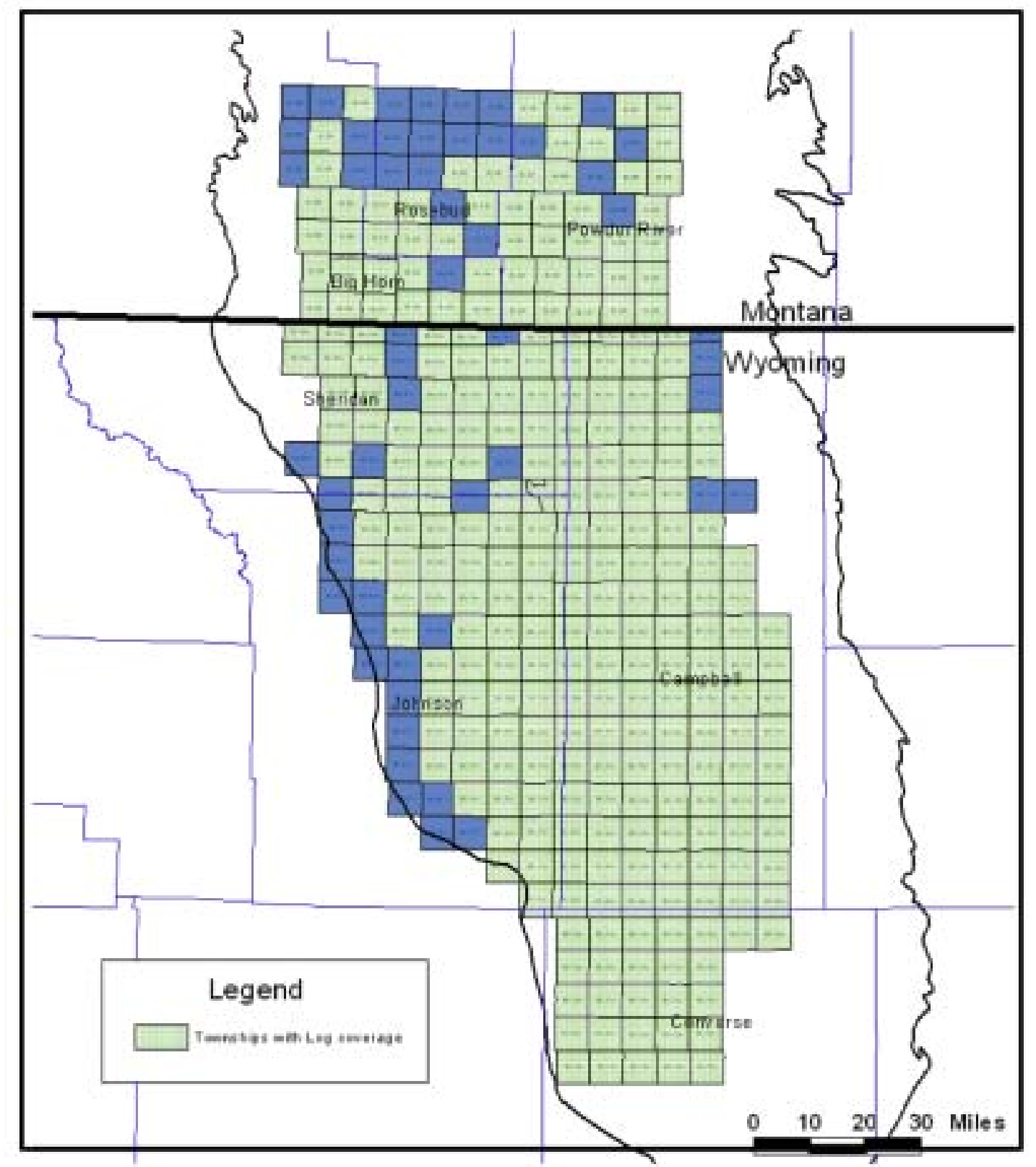

Figure 1-7. Townships with CBM Well Logs Analyzed for this Report. 


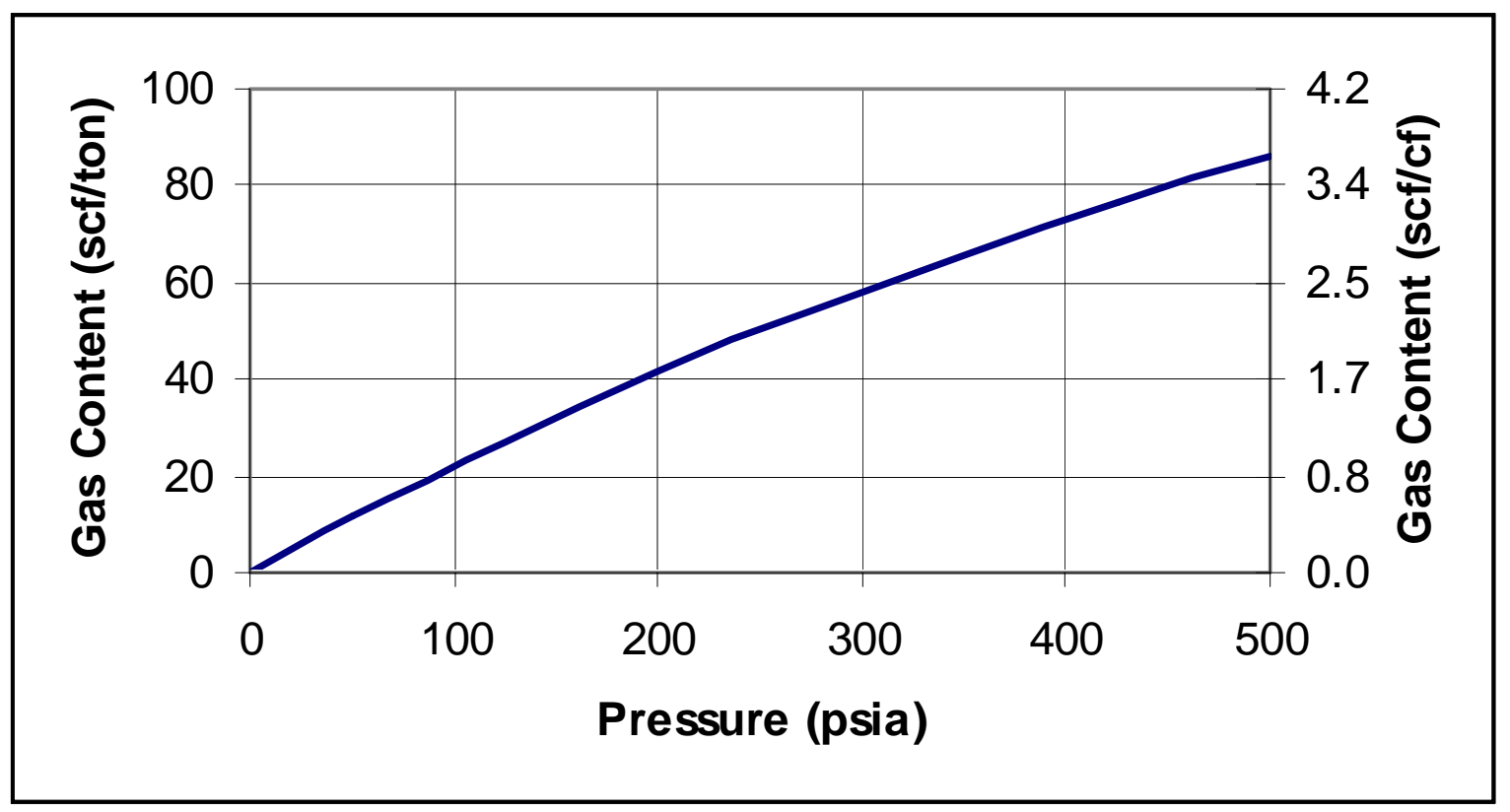

Figure 1-8. Gas Content Isotherm Used for Powder River CBM MSC Technology.

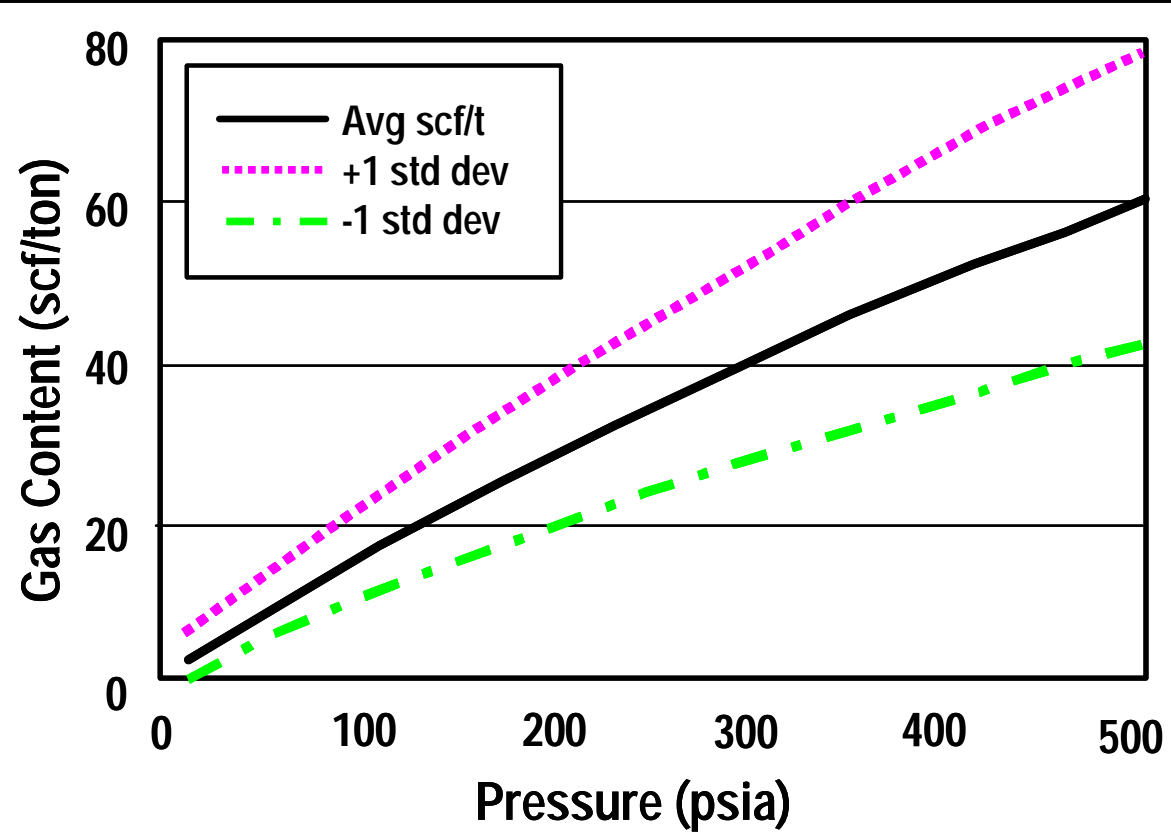

Source: From Wyoming EIS support documents, 2002. Average synthesized adsorption isotherm for 41 coal samples from the PRB, based on a compilation of data from public and private sources.

JAF02188.PPT

Figure 1-9. Average Synthesized Adsorption Isotherm for Coals in the Powder River Basin. 
Canvassed operators and assembled well completion and production records on the use and performance of MSC technology in the basin, as further discussed in Section 3. This helped to identify problems with current technology, to compare multi-seam performance with single-seam technology performance (in a similar geologic setting), and to examine why simple transfer of multi-seam technology from other CBM basins has not worked in the Powder River Basin.

For a more comprehensive discussion of the reservoir characterization, production analysis, and cost model for the Powder River Basin, readers are directed to DOE's previously referenced (produced water management) study.

\subsection{Summary of Findings}

The Powder River Basin has numerous sequences of thin coal seams that extend over major areas of the basin, particularly along the northern portion of the basin, and in Montana. The inclusion of these thin (less than 20 feet of thickness) coals and their production using MSC technology significantly increases the accessible technically CBM recoverable resource in this basin. Even more important, the economics of CBM development in the Powder River Basin can be improved, assuming the adaptation and successful application of MSC technology.

The current outlook for coalbed methane in the Powder River Basin and the role of MSC technology are summarized below:

1. The gas in-place in the Powder River Basin, including both thick coals and thin coals seams, is estimated at 75 Tcf. MSC technology enables a producer to link currently bypassed coal to a production well. This would provides access to a significantly larger portion of the CBM resource in the Powder River Basin than can be achieved with currently used single-seam well completion practices. Figure 1-10 shows the study's estimate of CBM gas in-place in the Montana (MT) and Wyoming (WY) portions of the Powder River Basin.

2. The technically recoverable coalbed methane resource in the Powder River Basin - assuming successful use of MSC technology - is estimated at 50 Tcf. 
MSC technology enables the CBM resource in thin coals to be co-produced with traditionally produced thick coals, significantly increasing the technically recoverable CBM resource in the basin. Figure 1-10 shows the technically recoverable CBM resource in the Montana and Wyoming portions of the Powder River Basin.

3. The economically recoverable coalbed methane resource is estimated to range from 24 to 38 Tcf. This estimate assumes a natural gas price of $\$ 3.50 / \mathrm{Mcf}$ at the Henry Hub and two different outlooks for the basis differential between the Henry Hub and the Colorado Interstate Gas (CIG) Hub.

Because of limited pipeline capacity and access to markets, the wellhead gas price in the Powder River Basin has, at times, been severely depressed. Basis differentials between the Henry Hub and the CIG Hub have increased from a historical average of $\$ 0.80 /$ Mcf to about $\$ 1.80 /$ Mcf. Under the first scenario examined by the study, a scenario where increasing natural gas production volumes from the PRB and other Rocky Mountain basins continue to exceed pipeline take-away capacity, the relatively high basis differential of $\$ 1.80 / \mathrm{Mcf}$ remains. Under the second scenario examined in this study, sufficient new pipeline capacity is built to return the basin differential, over time, to a more historic norm of about $\$ 0.80 /$ Mcf.

Figure 1-11 shows the economically recoverable CBM resource in the Powder River Basin for these two basis differential scenarios. Under the scenario (\#1) where basis differentials remain at current levels, economically recoverable CBM is reduced by $14 \mathrm{Tcf}$, and the Montana portion of the PRB CBM play becomes uneconomic to further develop.

4. Application of successful MSC technology to the Powder River Basin CBM play would add 20-plus Tcf of economically recoverable resource. Widespread, successful application of MSC technology for continued use of single-seam well completion technology would significantly increase the portion of the CBM resource that becomes economically viable. [This impact (benefit) of MSC 
technology is examined using a $\$ 3.50 / \mathrm{Mcf}$ (Henry Hub) natural gas price and the recent practice of using impoundments or shallow reinjection (in select areas of the basin) for produced CBM water management.]

As shown on Figure 1-12, under Scenario \#1, the continuation of today's high basis differentials, successful use of MSC technology would increase economically recoverable resources by 21 Tcf over continued use of singleseam technology. Under Scenario \#2 (represents a return to a historical basis differential of $\$ 0.80 / \mathrm{Mcf})$, successful use of MSC technology would increase economically recoverable resources again, by 21 Tcf over continued use of today's single-seam technology.

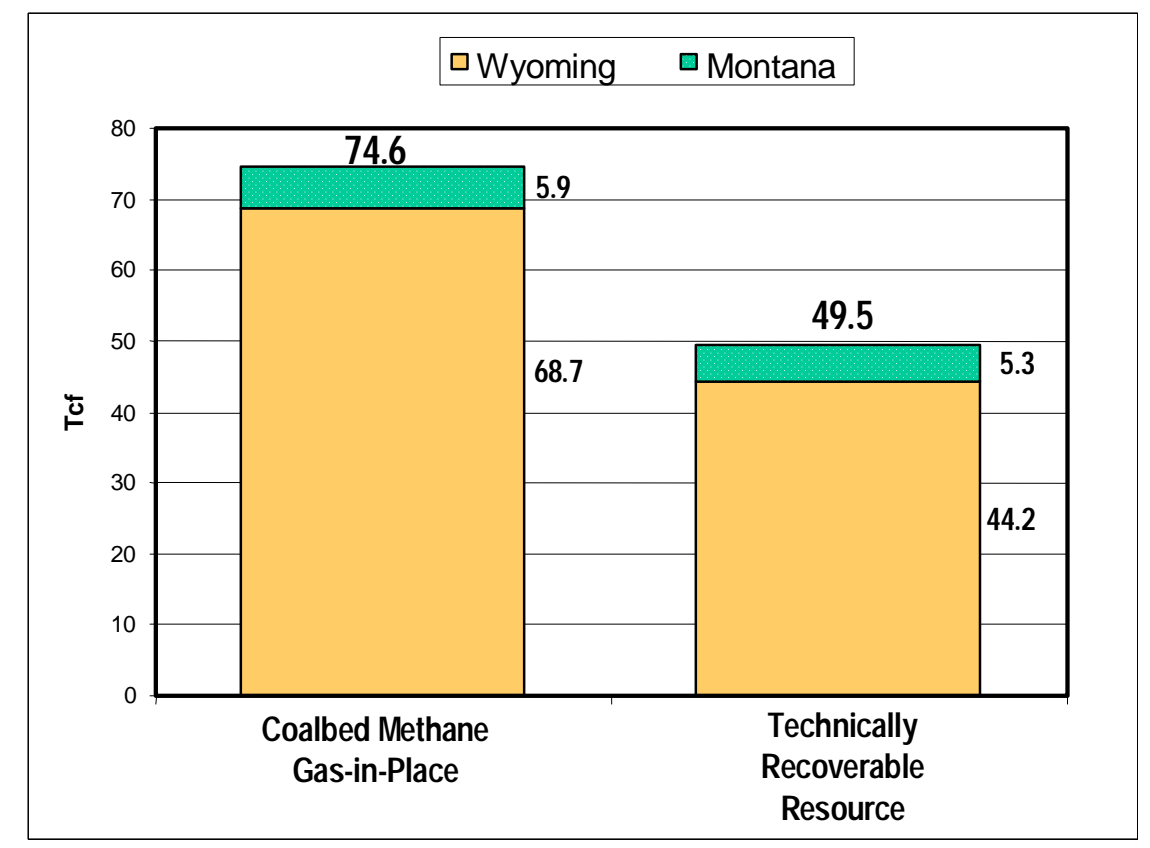

Figure 1-10. Gas-in-Place and Technically Recoverable CBM Resource, Powder River Basin. 


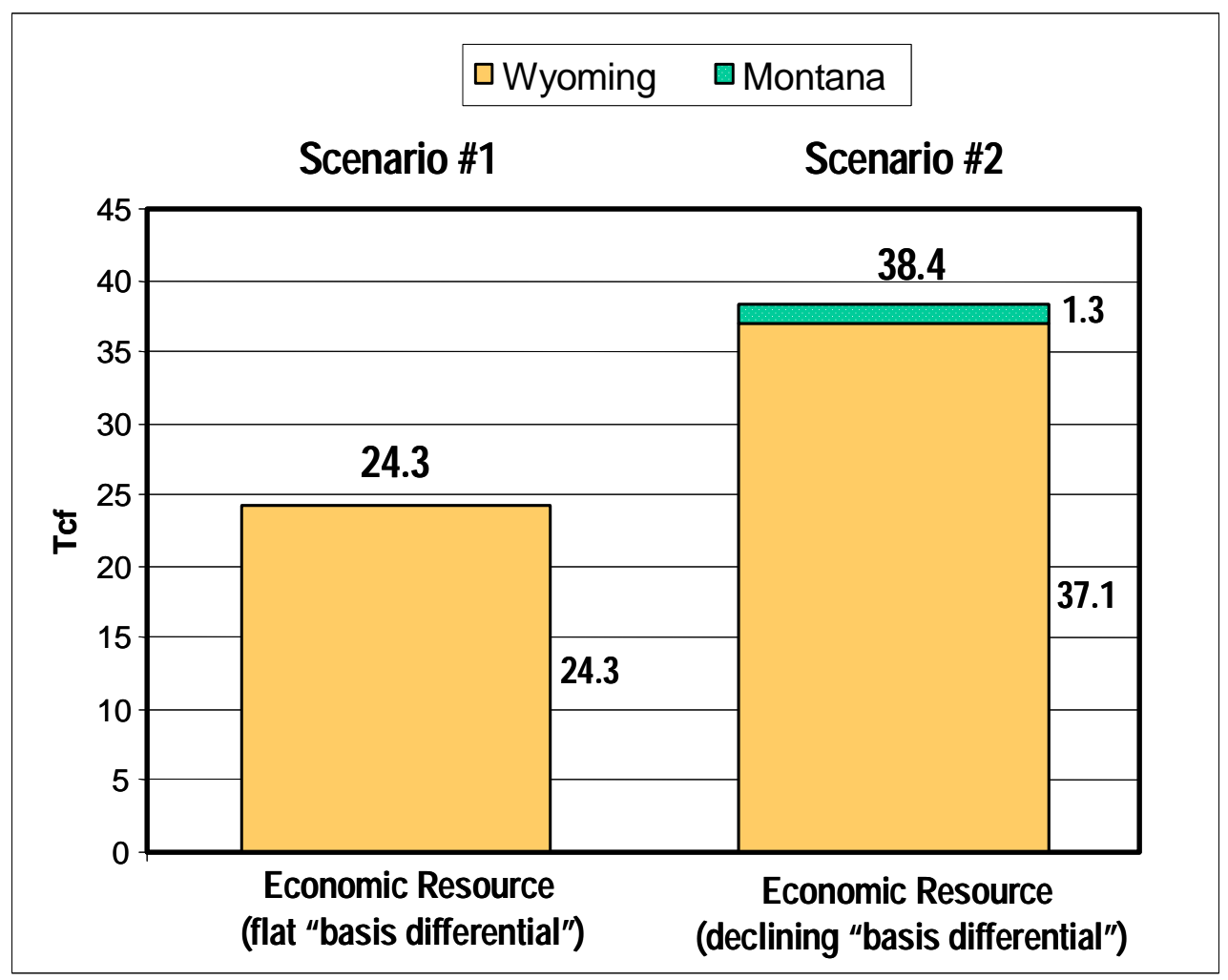

Figure 1-11. Economically Recoverable CBM Resources using MSC; Two Economic Scenarios, Powder River Basin.

5. Successful MSC technology would beneficially impact CBM development in the Powder River Basin in many ways, as illustrated by the following examples:

- In Example \#1, currently uneconomic, marginally thick coals are completed, along with a series of thin coals to make an economic well (discussed further below).

- In Example \#2, several thin coal seams that are bypassed under present practices are completed, along with a currently economic seam to increase reserves per well, while adding relatively little to costs beyond additional perforations/stimulation, a larger water lifting capacity and some increased operating and maintenance costs. 


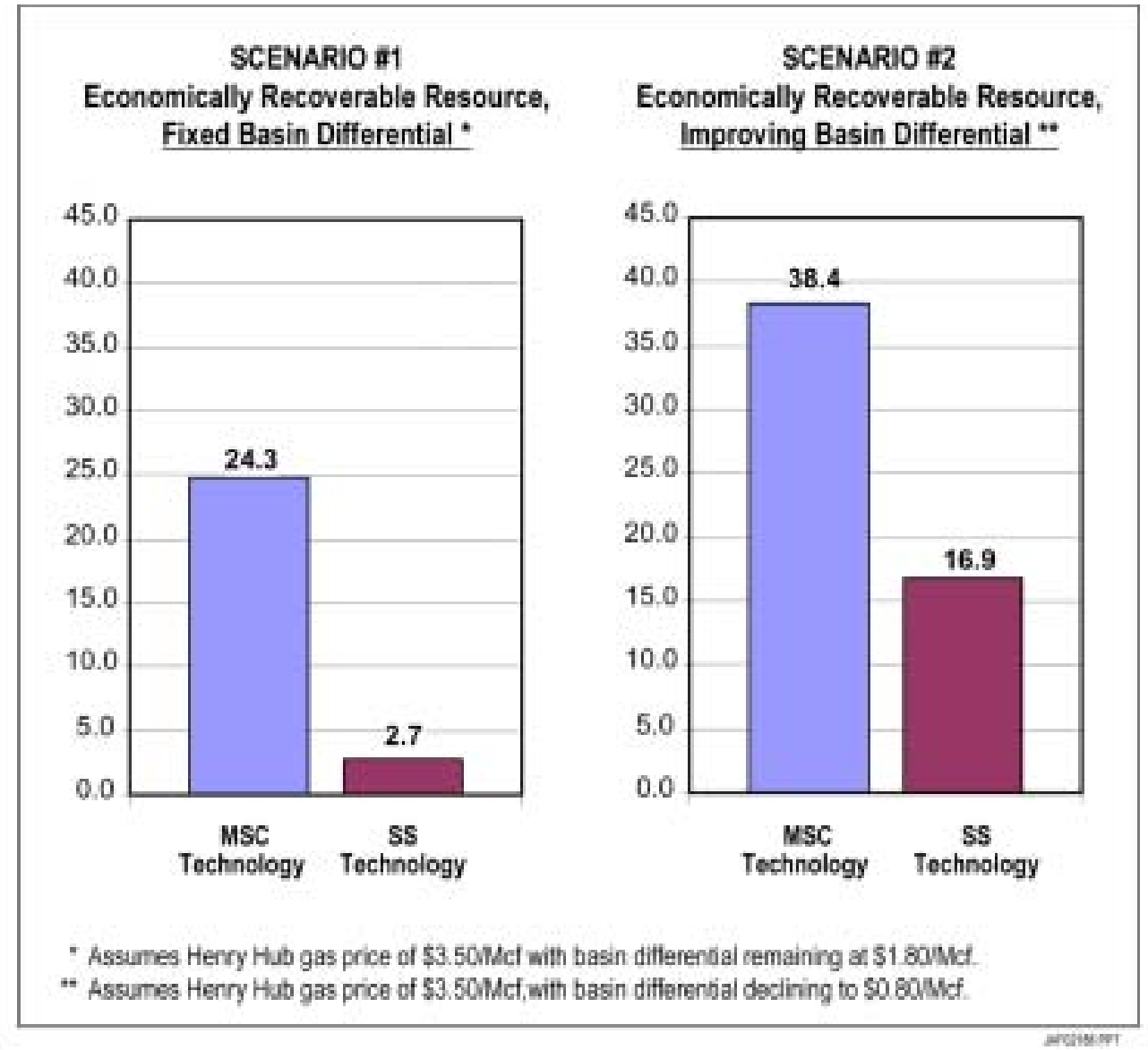

Figure 1-12. Economically Recoverable CBM Using Multi-Seam (MSC) and Single Seam (SS) Technology, Powder River Basin.

- In Example \#3, two (or more) economic seams are completed within the same well to reduce capital expenditures while cutting the required number of CBM wells in half (or less).

- In Example \#4, a basin area containing only thin coals is made economic by completing up to four seams in one well. This case is of particular importance in the northern portions of the play where thick (>20 ft.) coals are much less common. Without MSC technology such areas can be expected to remain undeveloped.

These four examples cover many of the geologic settings encountered in the PRB, including the central portion of the basin where thin seams coexist with major thick coals, as well as the northern and western basin flanks where much of the coal 
is deposited only in thin seams. Further examination of these four examples is provided in Section 5.8.

6. MSC technology has the potential for converting uneconomic, marginally thick seams and by-passed thin seams into economic reserves. In this elaboration of Example \#1, a single seam CBM well targeting the $25 \mathrm{ft}$. Canyon coal seam in T54N R80W is expected to recover $0.21 \mathrm{Bcf}$ of gas. With this low gas recovery, the well is sub-economic. With MSC technology, the Canyon coal seam in this township can be completed with three additional thin seams (16 ft., $19 \mathrm{ft}$., and $15 \mathrm{ft}$.) that would have been bypassed under current practices. The result is an economic CBM well that is expected to recover $0.57 \mathrm{Bcf}$. In addition, the packaging of four coal seams in one well significantly lowers finding and development (F\&D) costs in this township from an uneconomic $\$ 0.67 /$ Mcf to an economic \$0.27/Mcf.

The benefits of applying MSC technology in Example \#1 are summarized in Table 1-1 below:

Table 1-1. Multi-Seam Example \#1 - Marginally Economic Thick Coal Seam is Completed with Thin Seams to Make an Economic CBM Well

\begin{tabular}{|c|c|c|}
\hline & $\begin{array}{c}\text { Current Single-Seam } \\
\text { Technology }\end{array}$ & $\begin{array}{c}\text { Proposed Multi-Seam } \\
\text { Technology }\end{array}$ \\
\hline CAPEX/Well & $\$ 139,950$ & $\$ 154,960$ \\
\hline EUR/Well & $208 \mathrm{Mcf}$ & $566 \mathrm{MMcf}$ \\
\hline F\&D Cost & $\$ 0.67 \mathrm{per} \mathrm{Mcf}$ & $\$ 0.27 \mathrm{per} \mathrm{Mcf}$ \\
\hline
\end{tabular}

Additional detail on capital expenditure (CAPEX) costs is provided in Section 2.6.

7. Widespread use of MSC technology would significantly increase Montana, Wyoming, and Federal revenues. Another benefit of successful use of MSC technology would be increased royalty, severance, and ad valorem payments to state and federal governments. Under Scenario \#2, with an economic resource base of 38.4 Tcf, royalty payments to local, state, and federal budgets from application of MSC technology would be $\$ 6.4$ billion, an increase of $\$ 3.6$ billion 
over royalty revenues that would be generated from continued use of current well completion practices. $\$ 7.4$ billion in severance and ad valorem taxes $(\$ 0.2$ billion for MT; $\$ 7.2$ billion for WY) would be generated from successful application of MSC technology. This is an increase of $\$ 4.1$ billion ( $\$ 0.2$ billion for MT; $\$ 3.9$ billion for WY) over severance and ad valorem taxes that would be generated from continued use of current completion practices.

Table 1-2 provides a summary of these revenue benefits for Montana, Wyoming, and the federal budget; using the royalty and severance tax information in the economic model discussed in Section 2.6.

Table 1-2. Royalty and Severance/Ad Valorem Tax Receipts Under Two Technology Options.

\begin{tabular}{|l|c|c|c|c|c|c|c|c|c|}
\hline \multirow{2}{*}{$\begin{array}{l}\text { Revenue } \\
\text { Sources }\end{array}$} & \multicolumn{3}{|c|}{$\begin{array}{c}\text { With MSC } \\
\text { Technology }\end{array}$} & \multicolumn{3}{c|}{$\begin{array}{c}\text { With Single Seam } \\
\text { Technology }\end{array}$} & \multicolumn{3}{c|}{ Benefit of MSC Technology } \\
\cline { 2 - 10 }$y$ & MT & WY & Federal & MT & WY & Federal & MT & WY & Federal \\
\hline $\begin{array}{l}\text { Royalties } \\
\text { (millions of \$) }\end{array}$ & $\$ 30$ & $\$ 819$ & $\$ 5,536$ & - & $\$ 373$ & $\$ 2,433$ & $\$ 30$ & $\$ 446$ & $\$ 3,103$ \\
\hline $\begin{array}{l}\text { Severance/ Ad } \\
\text { Valorem Taxes } \\
\text { (millions of \$) }\end{array}$ & $\$ 203$ & $\$ 7,197$ & - & - & $\$ 3,278$ & - & $\$ 203$ & $\$ 3,919$ & - \\
\hline
\end{tabular}




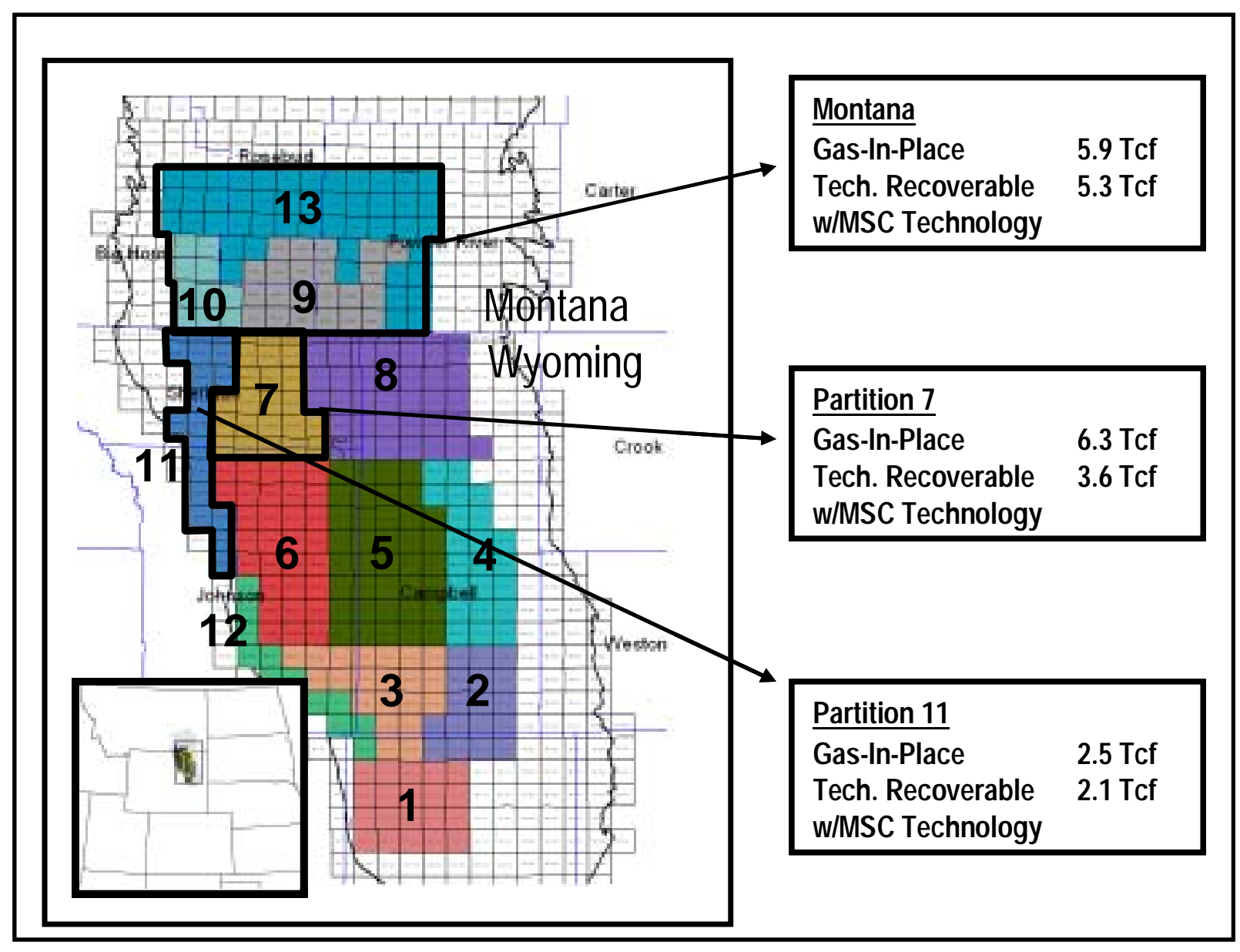

Figure 1-13. Areas with an Abundance of Thin Seams Requiring Multi-Seam Completion Technology for Economic Development, Powder River Basin.

8. Multi-Seam technology is essential for developing the CBM resource in Montana and on Indian lands, areas that contain an abundance of CBM resource in thin coal seams. The CBM play in Montana and the northern Wyoming portion of the Powder River Basin has the bulk of its resource in thin ( $<20 \mathrm{ft}$.) seams and in sub-economic thick coal seams. Without MSC technology, very little future development is expected to take in these areas. Figure 1-13 shows the gas-inplace and technically recoverable coalbed methane resource estimates for three areas of the PRB where multi-seam technology is vital for development.

9. Multiple coal seam well completions, developed and successfully applied in other CBM basins, have not been widely successful in the Powder River Basin. CBM operators in the Powder River Basin, recognizing the potential of MSC technology, have attempted to implement multi-seam well completion techniques developed in other coalbed methane plays. The results, however, have been 
disappointing due to the challenges arising from the geologic and reservoir conditions unique to the Powder River Basin-shallow, underpresssured, lowrank (low strength) coals surrounded by water-bearing aquifers. These reservoir conditions cause standard cased hole well drilling and completion practices to create extensive damage to the coal face and call for a set of practices and technologies appropriate to overcoming these unique reservoir conditions.

An initial or cursory review of the use of well completion practices in other basins with multiple coal seams shows that this development approach, when properly adopted, can be successful. The operators in each of these basins have modified the procedures and technologies to the specific geologic and reservoir conditions of the coals in each basin. Similar types of modifications are required to successful apply MSC technology in the PRB.

This study provides a major update to previous work by DOE/Advanced Resources International for the Powder River CBM play. The primary differences between this report and previous studies are: (1) incorporation of MSC technology for CBM development in this basin; (2) the inclusion of thin coal seams in large areas of the basin; (3) expanding the study area particularly in Montana; (4) developing an updated methane adsorption isotherm specific to PRB coals; and, (5) using a revised outlook for future gas prices and for the basis differential for the PRB. Each of these changes helps provide a more comprehensive, up-to-date assessment of the resource potential and technology impacts related to coalbed methane development in the Powder River Basin.

The analysis clearly shows that advanced MSC technology can help improve the outlook for CBM in the Powder River Basin by improving the reserves-per-well, and by reducing environmental impact due to drilling fewer wells. There is sound reason to believe that, with a well designed and executed field R\&D project, MSC technology will work in the PRB. As documented herein, MSC technology works in other CBM basins (such as the Warrior Basin) and is essential for making CBM 
development in these basins economic. There is no intent to overestimate the natural gas (CBM) recoverable from the PRB in this report. Rather, the purpose of the report is to estimate the impacts of a successful technology program, and industry's subsequent implementation of that program, throughout the PRB. While there is uncertainty associated with all field $R \& D$, pursuing MSC technology is one area that offers both a high potential for success and a high value.

Other actions, however, are still required to reach optimum development of this major domestic natural gas resource. These actions include improving market access for the produced natural gas, reducing gathering costs, establishing optimum well spacing, resolving the gas content and gas saturation issues (particularly for the deeper coals), and developing lower-cost water management options. These topics set the stage for further actions and technology development, all leading to more optimum production of the basin's vast coalbed methane resource. 


\section{SECTION 2. STUDY APPROACH AND METHODOLOGY}

\subsection{Basin Area}

The Powder River Basin is one of a series of coal-bearing basins along the Rocky Mountains, stretching from northern New Mexico to central Montana. The basin covers approximately 28,500 square miles, with about one-half of this area underlain by producible coals. The basin is bounded on the east by the Black Hills uplift, on the north by the Miles City Arch, on the south by the Laramide Mountains, and on the west by the Big Horn Uplift and the Casper Arch.

The bulk of coalbed methane activity to date has been in the east and central portions of the basin, around the town of Gillette, in Campbell County, Wyoming. To date, over 14,000 coalbed methane wells have been drilled in the Powder River Basin, providing a wealth of data for establishing the geologic setting and characteristics of the Wasatch and Fort Union Formation low-rank coals in this basin. However, the great bulk of the basin, particularly the deeper coals, still remains underdeveloped, requiring considerable extrapolation of the data and well performance for assessing the full basin.

Figure 2-1 shows the outline of the Powder River Coal Field and coalbed methane basin in Wyoming.

\subsection{Basin Structure}

The eastern flank of the Powder River Basin dips gradually toward the basin center at an average of $1.5^{\circ}$ and is characterized by occasional normal faulting and folding (Figure 2-2). The basinal axis runs along the steeper western and southern margins, where the basin terminates against a complex of basement thrusts and reverse faults, as shown on the generalized cross-section of the Powder River Basin (Figure 2-3). 


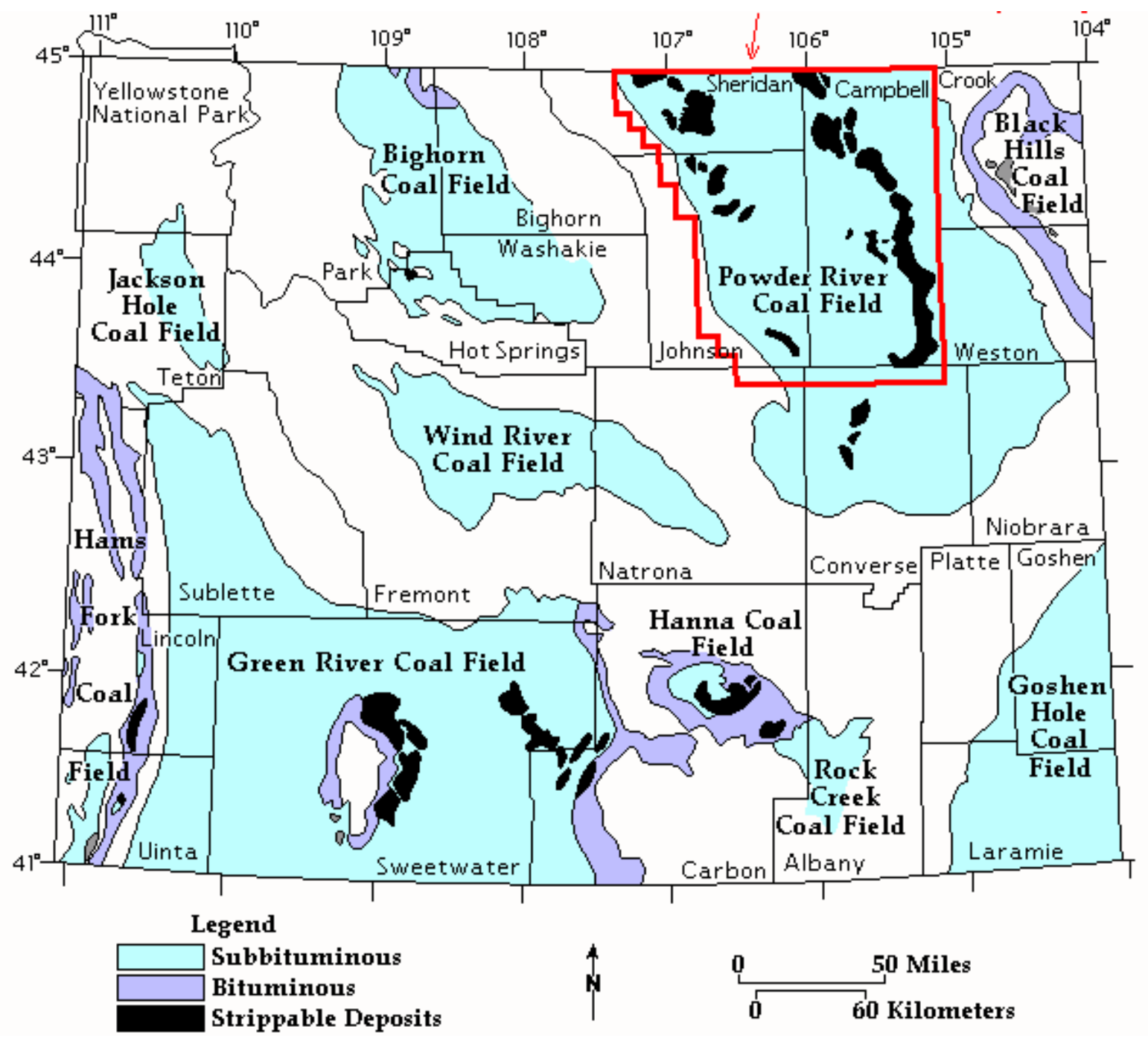

Source: "Coalbed Methane Activity in the Powder River Basin, Wyoming", Wyoming State Geologic Survey.

Figure 2-1. Coal Basins of Wyoming. 


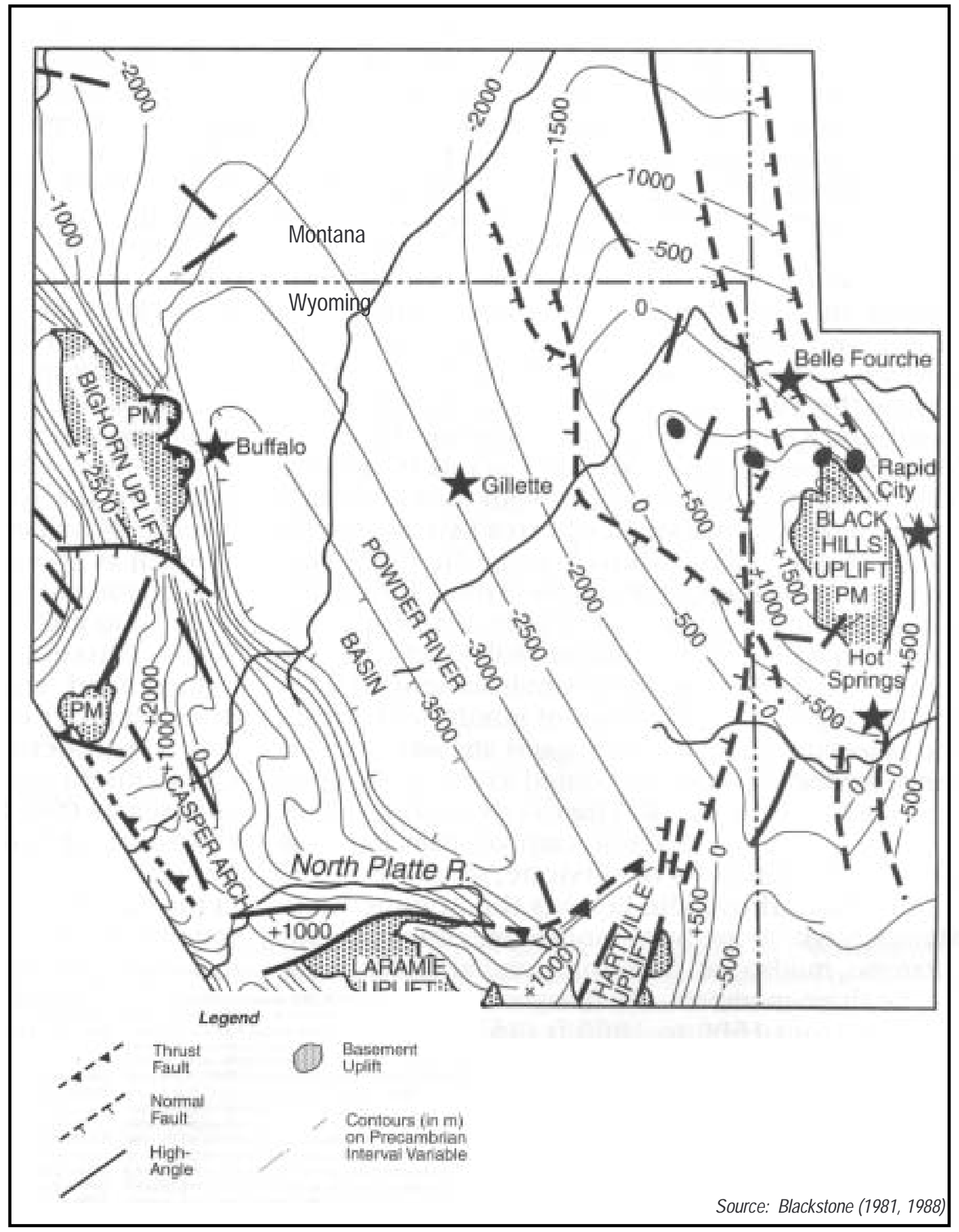

Figure 2-2. Regional Structure and Tectonic Map of the Powder River Basin. 


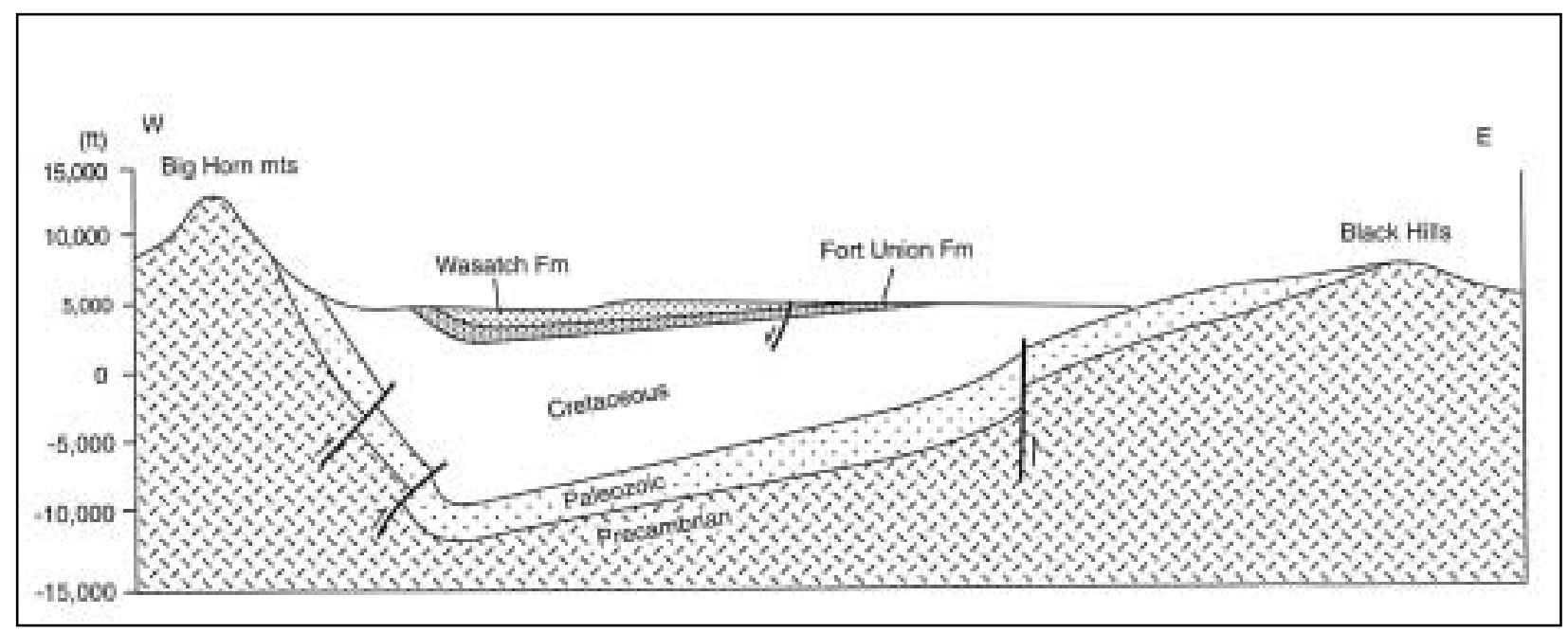

Source: Montgomery, 1999.

Figure 2-3. Regional Cross-Section of the Powder River Basin.

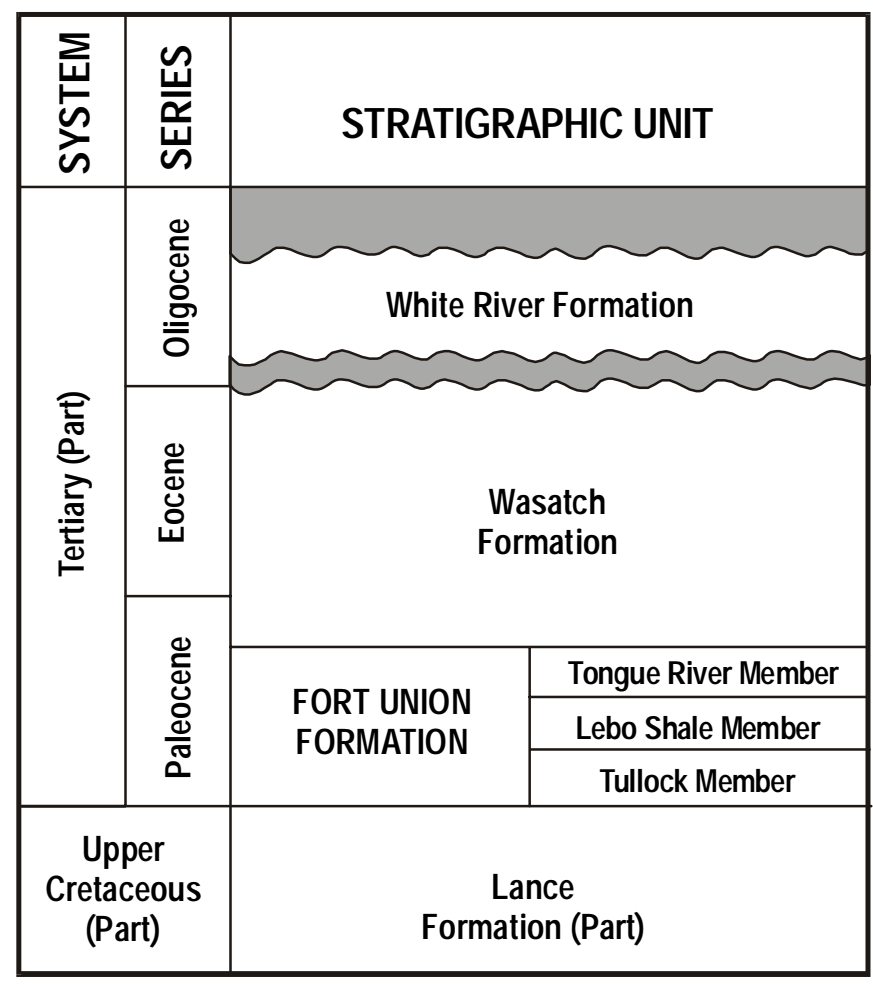

Source: Law, Rice and Flores, 1991.

Figure 2-4. Upper Cretaceous and Tertiary Stratigraphic Chart for Powder River Basin. 


\subsection{Basin Stratigraphy}

The Powder River Basin (PRB) is filled with thick tertiary-age marine and fluvial deposits. The tertiary units contain the coal-bearing Fort Union and Wasatch formations are the topic of this study (Figure 2-4).

The Tongue River Member, consisting of sandstone, conglomerate, siltstone, limestone, and coal, is the principal coal-bearing unit of the Fort Union Formation. The Tongue River Member contains a large number of distinct coal seams, ranging from a few feet to over 100 feet in thickness (Figure 2-5).

The Tongue River Member can be further divided into upper and lower units. The Upper Tongue River unit contains the Smith/Swartz, Anderson (Deitz), Canyon (Monarch), Wyodak (where the Anderson and Canyon have merged), the Big George and the Cook (Carney) seams. The Lower Tongue River unit contains the Wall, Pawnee, Cache, and deeper coal seams.

A series of Wasatch Formation coals exist on the western edge of the basin and include the Cameron, Felix, and Ucross seams. These coals coalesce into a thick coal package at Lake Desmet.

In the Montana portion of the PRB, the Tongue River Member coals become shallower and outcrop. Several deeper seams, without exact equivalents in the Wyoming portion of the basin, become available for CBM development in Montana, including the Knobloch coal seam, which has been given particular attention in this study. 


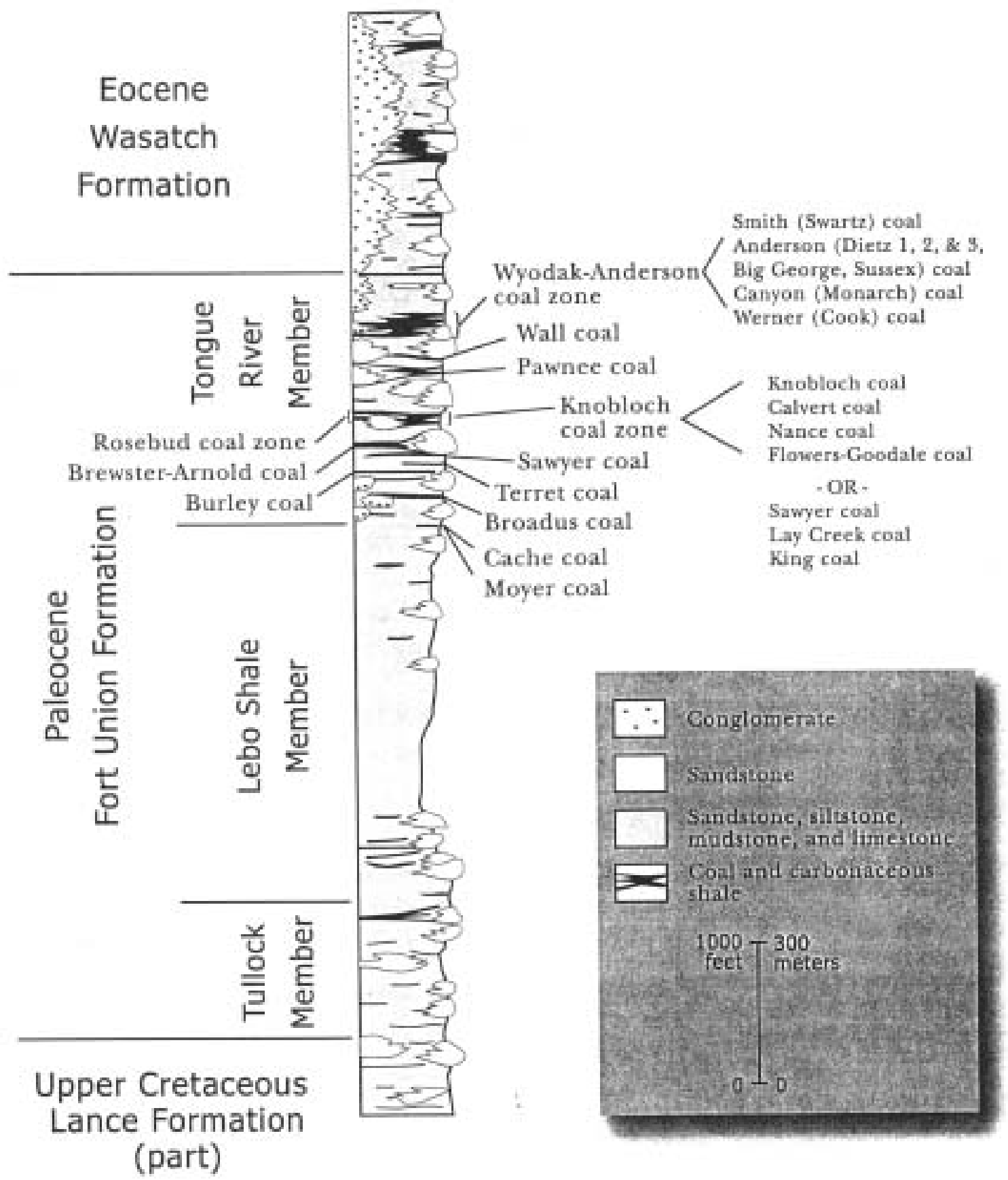

Source: WOGCC, 2002.

Figure 2-5. Coal Bearing Units of the Tongue River Member of the Fort Union Formation. 


\subsection{Reservoir Parameters}

Knowledge of the coal seam reservoir parameters is integral to understanding how CBM wells will perform. Several properties, including coal depth and thickness, pressure gradient, gas content, and gas saturation, were assessed to estimate gasin-place for each coal seam in each township. Water in-place was estimated using coal fracture and matrix porosity. Reservoir permeability provided estimates of recoverable gas and water, and their timing. Lastly, "type wells" constructed from over 1,400 Powder River Basin CBM wells were modeled using a CBM reservoir simulator to estimate gas and water production streams over a 10-year well life. Considerable more information on the assembly of key reservoir parameters and the assessment methodology used is provided in the original basin study. ${ }^{1}$

As an example of detailed information required for this comprehensive analysis, the reservoir properties for a CBM development area in the east-central portion of the Powder River Basin are shown in Table 2-1.

Table 2-1. Representative PRB Reservoir Properties*.

\begin{tabular}{|c|c|c|c|c|c|c|}
\hline \multirow{2}{*}{$\begin{array}{l}\text { Coal } \\
\text { Seam }\end{array}$} & \multirow{2}{*}{$\begin{array}{c}\text { Gas } \\
\text { Content }\end{array}$} & \multirow{2}{*}{$\begin{array}{c}\text { Pressure } \\
\text { (Top of Coal) }\end{array}$} & \multicolumn{2}{|c|}{ Free Gas Saturation } & \multicolumn{2}{|c|}{ Porosity } \\
\hline & & & Fracture & Matrix & Fracture & Matrix \\
\hline & $(\mathrm{cf} / \mathrm{t})$ & (psi) & $(\%)$ & $(\%)$ & $(\%)$ & $(\%)$ \\
\hline Anderson & 30 & 141 & 8 & 10 & 0.2 & 1.5 \\
\hline Canyon & 36 & 171 & 7 & 7 & 0.4 & 3.0 \\
\hline Wyodak & 41 & 200 & 5 & 10 & 1.0 & 6.0 \\
\hline Cook & 52 & 260 & 0 & 1 & 0.1 & 2.4 \\
\hline Wall & 63 & 340 & 0 & 0 & 1.0 & 10.0 \\
\hline Pawnee & 82 & 460 & 0 & 0 & 0.5 & 5.0 \\
\hline Cache & 94 & 560 & 0 & 0 & 0.5 & 5.0 \\
\hline
\end{tabular}

${ }^{*}$ For one major PRB partition area, as modified/updated 


\subsubsection{Regional Pressure Gradient}

A regional pressure gradient versus depth relationship for PRB coal seams, Figure 2-6, was constructed to establish reservoir pressure for each of the coal formations. This was generated using:

- Detailed hydrology data and pressure mapping by the Wyoming Bureau of Land Management (BLM),

- Actual pressure data from basin producers, and

- History matching of the pressure gradient data using long-term (4+ year) gas and water production in the PRB.

\subsubsection{Gas Content}

Gas content and isotherm data, appropriate for the low rank coals of the PRB, were assembled from the following sources:

- Recently collected gas content and isotherm data by industry, the United States Geological Survey (USGS), and the Bureau of Land Management (BLM).

- Gas content and isotherm data collected by Advanced Resources International in analogous low rank coals in other basins, and

- History matching of long-term (4+ year) gas and water production data in the PRB to establish gas content values and a volumetrically consistent isotherm.

The coalbed methane isotherm used in this study, shown in Figure 2-7, is an update of the isotherm used in the previous study. For comparison, a gas content isotherm from past data collected by the BLM in Wyoming is shown in Figure 2-8. 


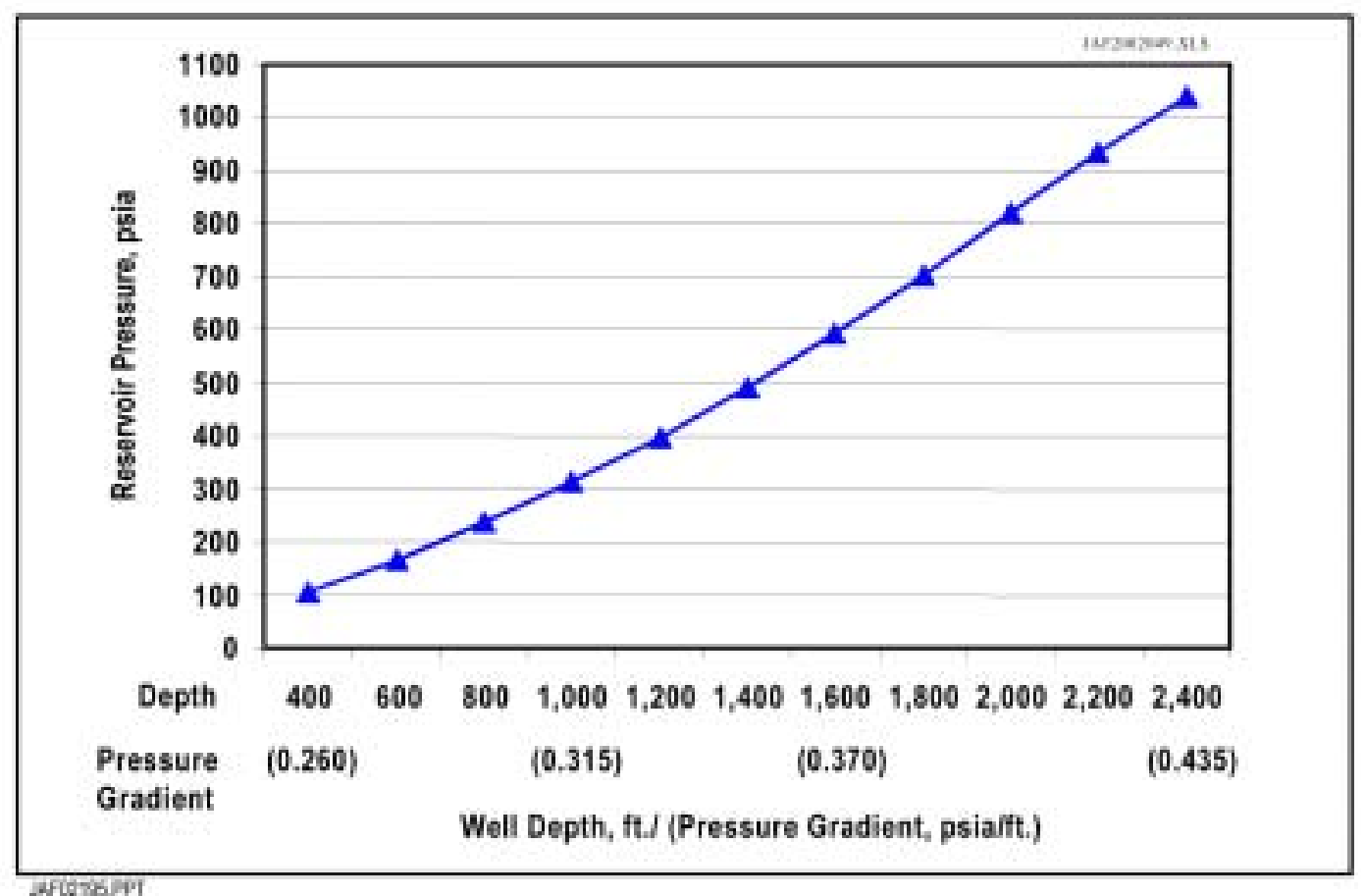

Figure 2-6. Reservoir Pressure Profile Used for PRB Study.

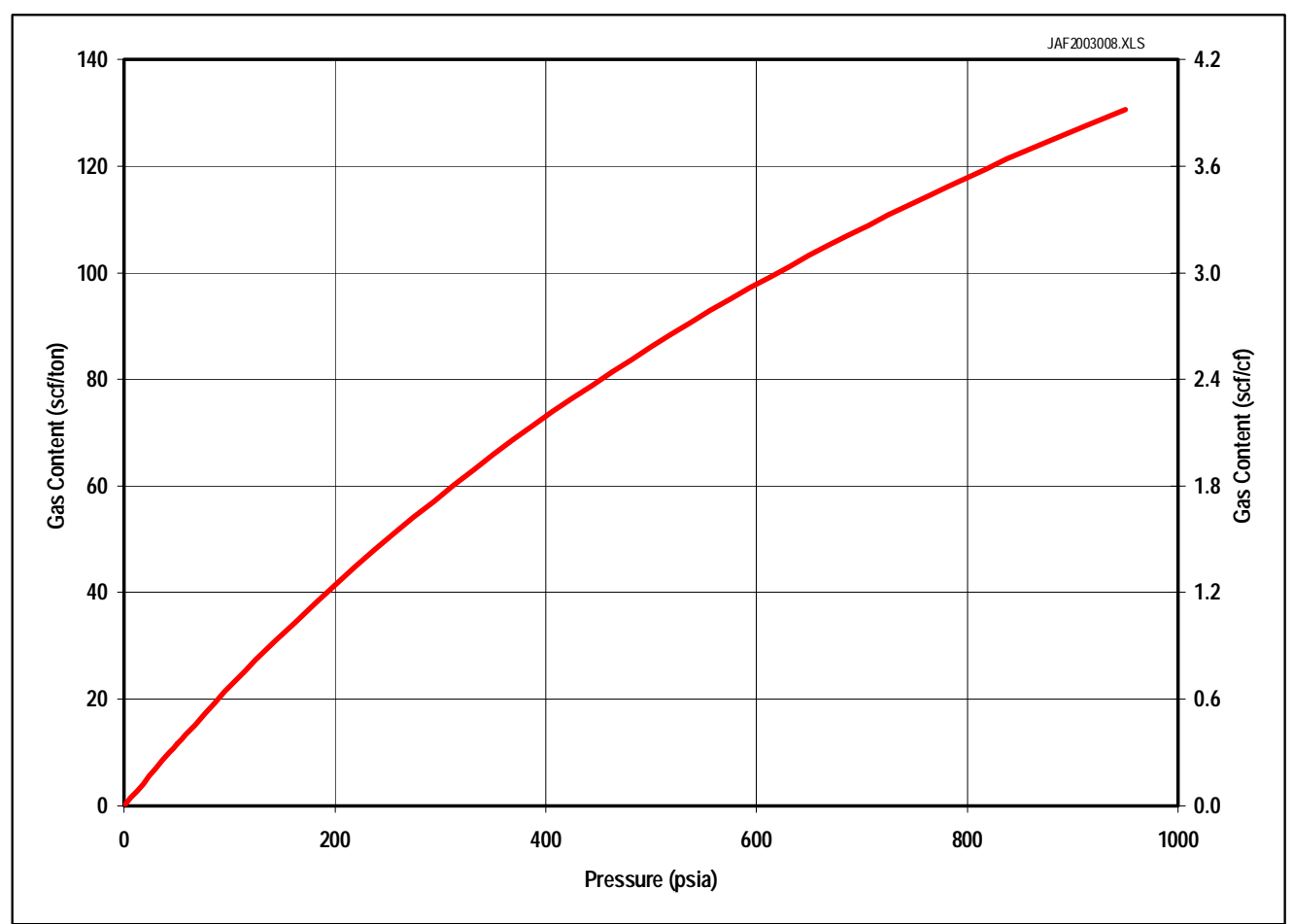

Figure 2-7. Gas Content Isotherm Used for MSC Study. 


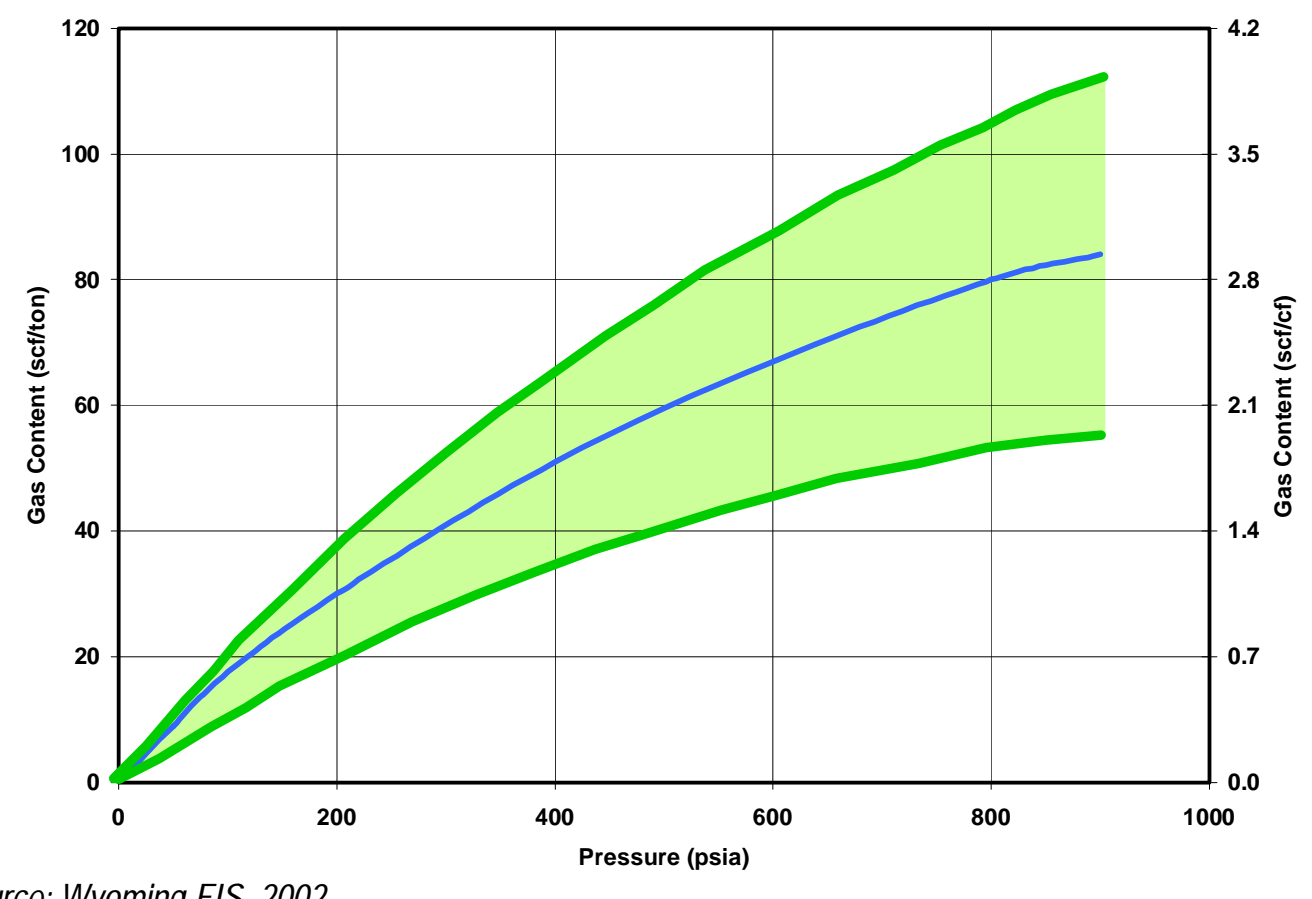

Source: Wyoming EIS, 2002.

Range of values represents \pm 1 sigma in the data.

Figure 2-8. Average Synthesized Adsorption Isotherm for Coals in the Powder River Basin.

\subsubsection{Gas Saturation}

The nature of early time water and gas production was used to establish whether the PRB coals were undersaturated, fully saturated, or contained free gas in the pore space:

- A series of fourteen individual coal seams and production data sets were assembled involving gas and water production data from over 1,400 PRB CBM wells.

- History matching of production data was used to establish the level of gas saturation and presence of free gas in the coal cleat and matrix system.

Overall, the study determined that the coals are fully saturated with methane (at the reduced reservoir pressure conditions that generally exist in the basin) and that modest amounts of free gas exist in the matrix porosity and coal cleat (fracture) porosity systems in certain of the seam/partition data sets. 
However, operators report that low gas content and undersaturated conditions may exist for certain of the deeper coals in the central portion of the basin, south of Gillette. Collection, analysis, and reporting of additional gas content data would help define the potential gas content problem areas and seams in the basin.

\subsubsection{Coal Fracture and Matrix Porosity}

History matching of water production was used to establish the fracture and matrix porosity for the PRB coals:

- In general, the coal cleat (fracture) porosity in the coals ranges from 0.1 to 1 percent, consistent with other data on fractured coals and reservoirs.

- The matrix porosity for these low rank coals varies widely, ranging from 1 to 10 percent, with highest matrix porosity in the Wyodak and Wall coal seams.

High coal matrix porosities would account for the relatively high water production from otherwise thinner (25 to 30 feet) seams, such as the Wall coal seam.

\subsubsection{Coal Permeability}

In general, the coal cleat (fracture) permeability of PRB coals is favorable, ranging from 35 to 500 millidarcy (md). Coal matrix permeabilities are considerably lower and variable, ranging from 0.001 to $1.0 \mathrm{md}$. However, even the lower end of the range for cleat and matrix permeabilities for these coals in the PRB is sufficient to support reasonable 10-year gas recoveries (technically recoverable) of 50 to $80+$ percent of the gas-in-place.

\subsubsection{Estimating Gas and Water Production}

Gas production and recovery were estimated on a per well basis using data gathered from actual producing Powder River Basin CBM wells. Producing wells were sorted by seam and their production streams were normalized from a data base of over 1,400 CBM wells with sufficient production data and confinement using time-zero plots. Figure 2-9 illustrates this data set for a group of 164 closely spaced 
Wyodak coal seam wells in the eastern portion of the basin. This process provided 14 history matched production streams from which permeability, coal porosity, gas and water saturation, and other data could be obtained via history matching.

- History matching was performed using a state-of-the-art reservoir simulator, a triple porosity and triple permeability finite difference model, specifically developed for coalbed methane production and reserve assessments.

- The history matched wells were extended in time to provide 10-year coalbed methane and water production rates and estimates of ultimate gas and water recovery (Figure 2-10).

- The 14 history matched wells were further modified using actual depth and thickness values for major seams, providing unique type wells for each major seam in each township of the basin.

- The gas and water production streams and recovery factors from these type wells were combined into distinct packages of coal (discussed further below) to create a series of multiple-seam completed CBM wells.

\subsection{Multi-Seam Coal Model}

\subsubsection{Coal Inventory}

A revised township-level coal database was assembled for all seams within the Powder River Basin, for coals thicker than 5 feet and deeper than 200 feet. Depth and thickness data for thick coal seams (seams thicker than 20 feet) were from an update of the original coal seam database. Data for thin coal seams are sparse however, and because current CBM completion practices bypass these seams, previous studies have not included these data. To account for these thin coal seams, 270 recent Powder River Basin CBM well logs that span the full Fort Union coal interval throughout the CBM play were evaluated. Depth and thickness data for all coal seams permitted correlation with ARI's existing database. Ultimately, well log data representing over 9,700 square miles of the CBM play were collected. 
Areas of missing data were primarily along the basin margins. These townships were often adjacent to areas with little or no coal, indicating that little CBM resource may exist in these basin areas. With time, exploratory CBM programs may help to fill the gaps in the database.

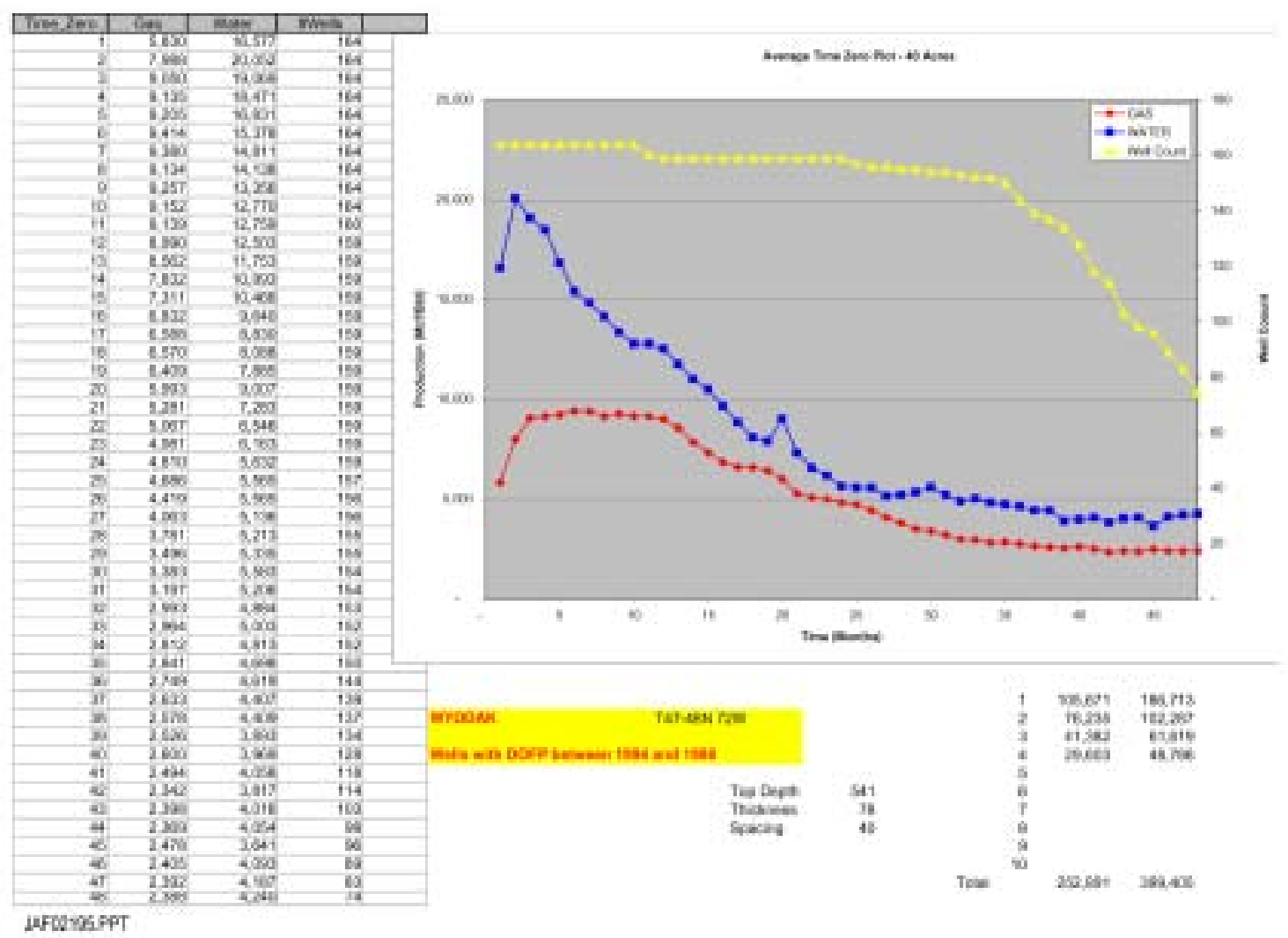

Figure 2-9. Wyodak Coal Seam Time-Zero Plot. 


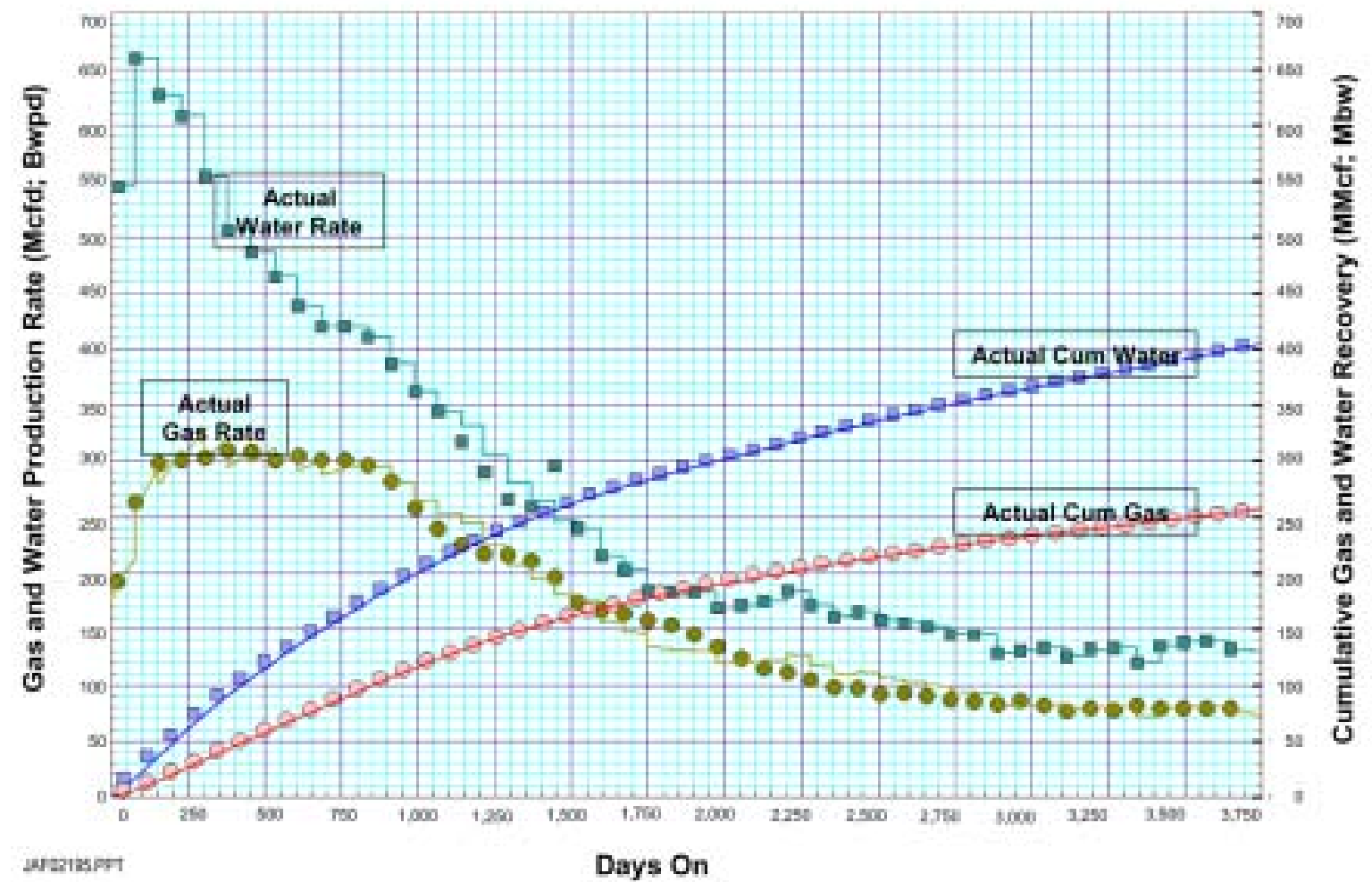

Figure 2-10. Wyodak Type Well History Match.

The other notable absence in data is along the northern edge of the play. Much of this area is on the Crow Indian Reservation that has not yet been explored or drilled for coalbed methane. Figure 2-11 displays the townships from which data were collected and used by this study.

\subsubsection{Coal Packages and Completion Criteria}

For consistency and comparison, three distinct coal packages were defined (each with a maximum of 4 individual coal seams). These were:

- Package \#1: The shallow Upper Fort Union, consisting of Wasatch formation seams through Anderson coal seams;

- Package \#2: The deeper Upper Fort Union, consisting of Canyon through Cook seams; and

- Package \#3: The Lower Fort Union, consisting of the Wall and deeper coal seams. 
To be included in one of the coal packages in Wyoming, a coal seam had to be at least 300 feet deep and have a thickness of 10 feet or more. In Montana, the depth and thickness criteria were relaxed to include seams at least 200 feet deep and 5 feet thick to more fully capture the coal resource in the northern part of the basin. In Montana, special efforts were made to collect and include stratigraphically deeper coal seams, such as the Knobloch seam, which exist near the northern edge of the Powder River Basin CBM play.

Figure 2-12 provides an example of the coal seam database assembled for this study, showing the individual coal seams and the aggregate coal thickness for each coal package. 


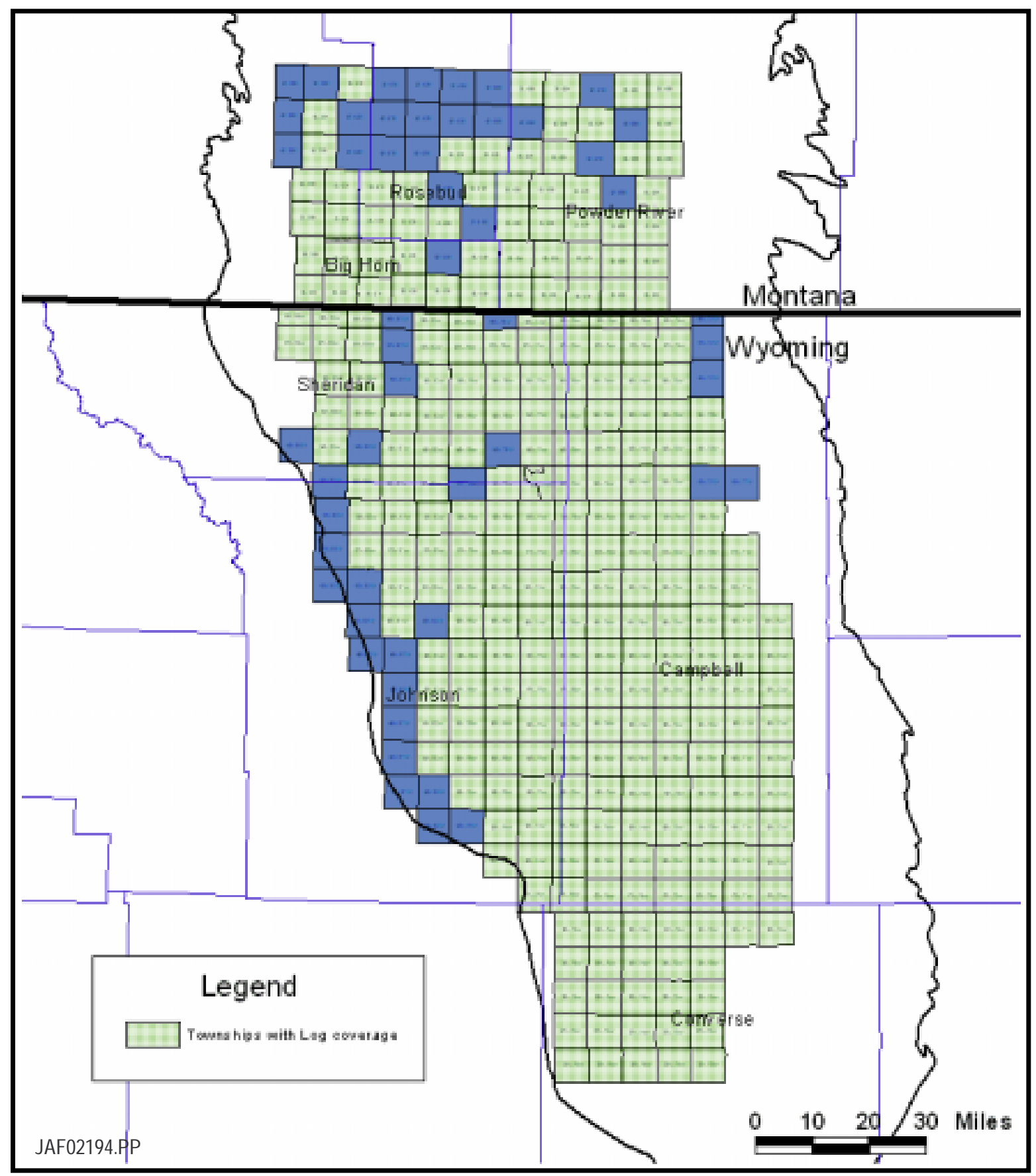

Few logs exist for areas in the northern Montana region and along the western edge of the play.

Figure 2-11. Map Showing Townships from which a CBM Well Log Was Analyzed for this Report. 


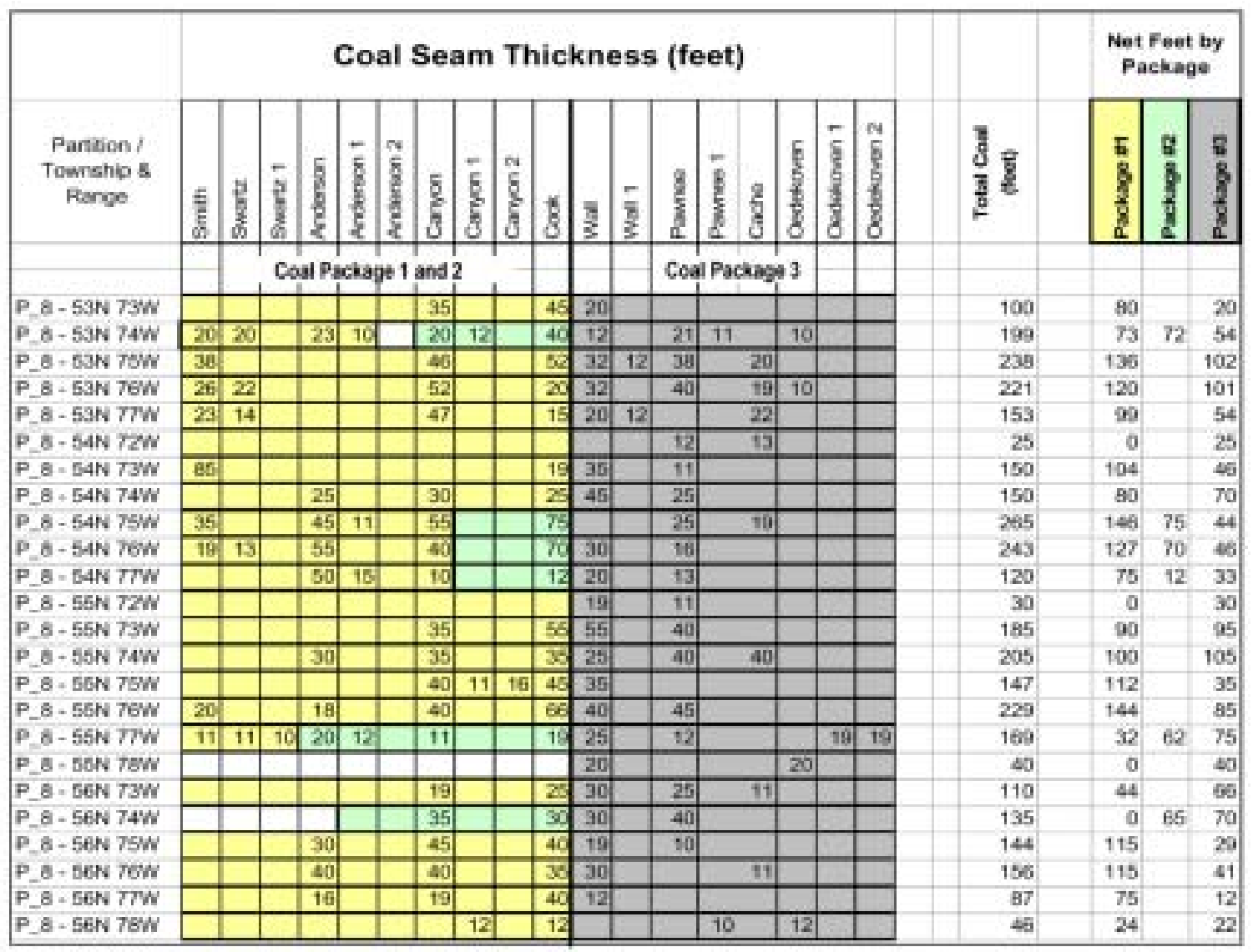

Figure 2-12. PRB Coal Database for 24 Townships in Partition \#8, Northeast Powder River Basin.

\subsubsection{Volumetric CBM Database}

With the reservoir data in hand, volumetric calculations were performed seam-byseam for an 80 acre well in each township to estimate:

- Gas-In-Place

- Technically Recoverable CBM Resource

- Ultimate Water Production

The gas and water production streams from three packages of multiplecompleted coals in T54N R76W are shown in Figure 2-13. 


\subsection{Basic Cost Model}

This study uses an updated version of ARl's coalbed methane cost and economic model, CECON (Coalbed Economics), to assess the feasibility of developing coalbed methane with multi-seam well completion technology. The model contains four main components: (1) basic capital costs; (2) basic operating and maintenance costs; (3) gas transportation and compressions costs; and (4) other costs.

The economic model incorporates forecasts for future natural gas prices (at the Henry Hub), current and anticipated Wyoming basis differentials, and royalties, production taxes, and other factors that impact CBM costs and economics. The economic model (before federal income tax; BFIT) is an industry-standard discounted cash flow (DCF) model that provides both an internal rate of return and the net present value (NPV) of an investment at various discount rates and at various net gas prices.

\subsubsection{Capital Costs for PRB CBM Well}

The basic capital costs for a PRB CBM well include outlays for land, permits, drilling and completion, infrastructure, and water management. These costs vary considerably by well depth, location and number of seams completed. For illustrative purposes, Table 2-2 shows the costs for a Powder River Basin coalbed methane well at 960 feet of depth, spaced on 80 acres, with 2 wells per pad. Capital costs are per well, assuming a 16 well, 8 pad development unit. Gas treating and compression is assumed to be provided by a third party contract and is included in annual operating costs.

This study assumes that impoundments and shallow re-injection would be used for produced CBM waters. (For a full description of the capital cost module and other water disposal alternatives, see DOE/NETL-2003/1184). The basic capital costs for the example PRB CBM well are estimated at $\$ 141,190$, as shown in Table 2-2. 
Table 2-2. Capital Costs for Illustrative CBM Well, Powder River Basin.

\begin{tabular}{|c|c|}
\hline Cost Item & Capital Costs \\
\hline Land Costs and Permits & $\$ 13,000$ \\
\hline Well Drilling and Completion (@960 feet) (1) & 91,070 \\
\hline Water Gathering (2) & 10,210 \\
\hline Water Disposal (3) & 10,290 \\
\hline Electric Power, including cable (4) & 8,460 \\
\hline Gas Gathering (5) & 7,820 \\
\hline Miscellaneous & 340 \\
\hline Total & $\$ 141,190$ \\
\hline
\end{tabular}

(1) Includes packer rental, cost of enhancement, and perforation charges.

(2) Allocated based on small diameter water gathering piping of 2,000 feet per well (including common trenching and survey for water, gas and electrical cable), central water transportation (2 lines) of 10,000 feet, right of way for 42,000 feet, two surface pumps; and, contingency, insurance and other of 10 percent.

(3) Allocated based individual well's share of the construction of a central processing facility and impoundment pond or shallow reinjection well.

(4) Allocated based on central 3-phase power installation costs of $\$ 75,000$ per unit, electrical cable of 2,000 feet per well, and contingency, insurance and other of 10 percent.

(5) Allocated based on small diameter gas gathering piping of 2,000 feet per well, central gas transportation (2 lines) of 10,000 feet, and contingency, insurance and other of 10 percent. 


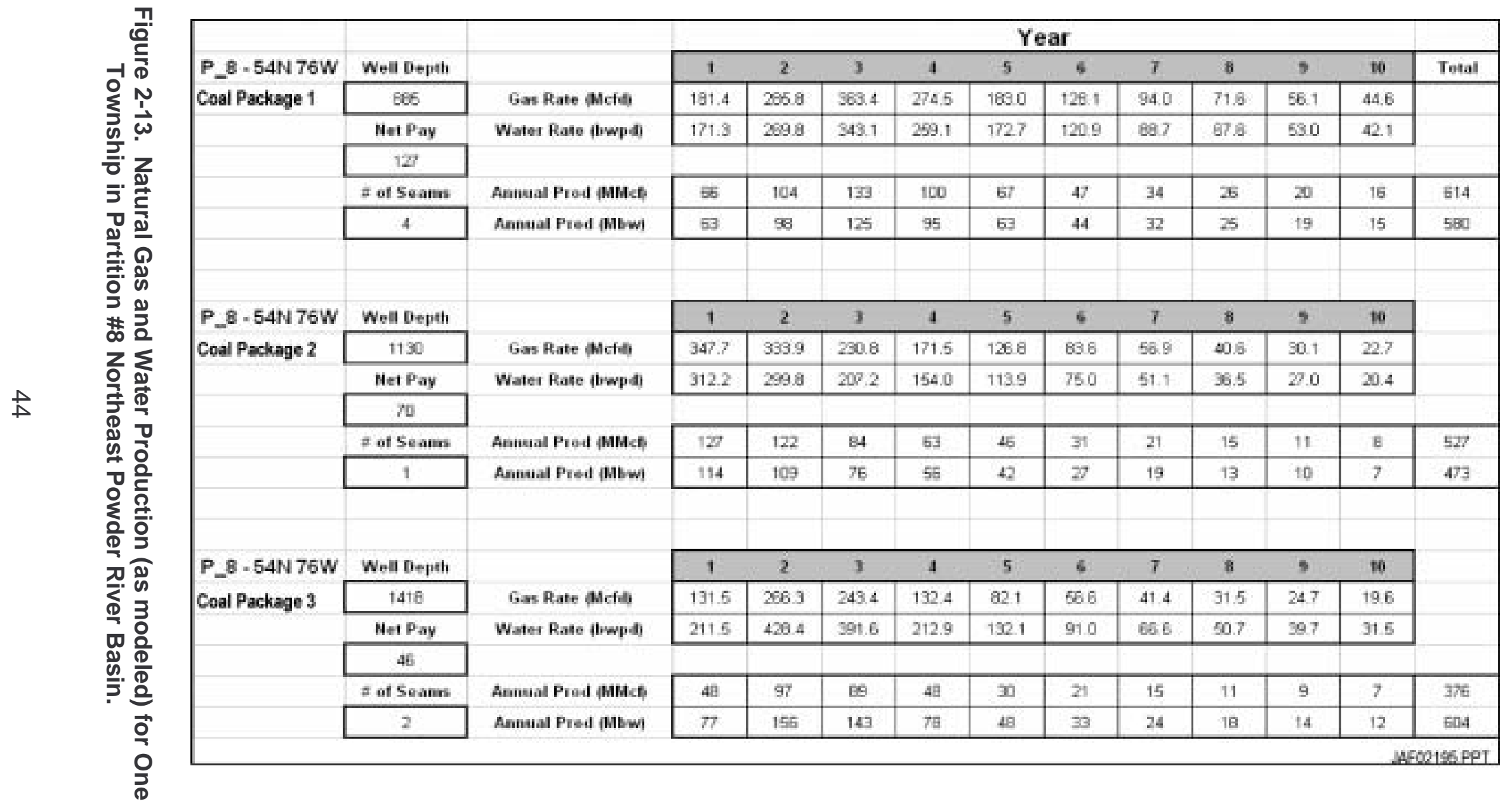




\subsubsection{Operating \& Maintenance Costs for PRB CBM Well}

The basic lease and well operating and maintenance (O\&M) costs for a Powder River coalbed methane well vary by year of production, with higher costs during the initial years because of more frequent well enhancements and pump replacements.

\begin{tabular}{|c|c|c|}
\cline { 2 - 3 } \multicolumn{1}{c|}{} & \multicolumn{2}{c|}{ O\&M Costs/Well ${ }^{*}$} \\
\cline { 2 - 3 } \multicolumn{1}{c|}{} & Annual & Monthly \\
\hline Year 1 & $\$ 26,540$ & $\$ 2,210$ \\
\hline Years 2 - & $\$ 16,990$ & $\$ 1,420$ \\
\hline Years 5 - 10 & $\$ 11,210$ & $\$ 930$ \\
\hline TOTAL (Years 1 - 10) & $\$ 144,770$ & $\$ 1,210$ \\
\hline
\end{tabular}

*Includes G\&A charge of 20\% for engineering, accounting, legal and other indirect costs.

For example, assuming CBM recovery of $0.58 \mathrm{Bcf}$ (gross) per well, the O\&M/G\&A costs are $\$ 0.25$ per Mcf.

\subsubsection{Gas Transportation, Compression, and Fuel Use}

The costs for gas treatment, compression, and transportation are subtracted from the PRB netback price to establish a PRB CBM wellhead price. The costs will vary, depending on the gathering system charges for transporting natural gas from the compressor to the Colorado Interstate Gas (CIG), or another hub, and on the nature and extent of contracted third-party compression. These costs depend on the location of the CBM development in the PRB, as follows:

- A charge of $\$ 0.43$ per Mcf is used for third party compression and dehydration (assuming no lease compression) and for transportation, for the central and southern portions of the PRB (Partitions \#1, 2, 3, 4, and 5).

- A charge of $\$ 0.57$ per Mcf is used for third party compression and dehydration (assuming no lease compression) and for transportation, for the northeast and southwest portions of the PRB (Partitions \#6, 8, 9 and 10). 
- A charge of $\$ 0.77$ per Mcf is used for third party compression and dehydration (assuming no lease compression) and for transportation, for the northwest and western portions of the PRB (Partitions \#7, 11, 12 and 13).

A fuel adjustment (shrinkage) for operating gas powered compressor stations, estimated at 4 to 6 percent of gross production, is subtracted from the sales volume. A second fuel adjustment (shrinkage), involving the Btu adjustment for CBM, generally 2 to 8 percent (to account for 920 to 980 Btu content gas), is also subtracted from the sales volume.

\subsubsection{Other Considerations}

Royalties. Royalty payments for PRB CBM production depend on mineral ownership, as set forth below:

- Royalties on Federal lands are 12.5 percent.

- Royalties on state lands are 16.7 percent.

- Royalties on private lands range from 15 to 20 percent.

- State Severance and Ad Valorem Taxes. State and county tax payments for PRB CBM production are state specific, as set forth below:

- Wyoming severance and ad valorem taxes are 12 percent.

- Montana severance taxes are 9.3 percent.

\subsubsection{Basis Differentials}

Because of higher transportation costs and other market conditions, the gas price at the CIG (or another Wyoming/Rocky Mountain) Hub is discounted from a marker price, set by the Henry Hub or NYMEX. (This is commonly called the basis differential). Currently (mid-March, 2003), with the Henry Hub gas price at $\$ 5.83$ per MMBtu, the Wyoming Pool Hub is at $\$ 4.08$ per MMBtu and the Opal Hub is $\$ 4.01$ 
per MMBtu, for a basis differential of about $\$ 1.80$ per MMBtu. Historically, the basis differential has been closer to $\$ 0.80$ per MMBtu.

\subsubsection{Economic Scenarios}

Two wellhead netback/basis differential scenarios were evaluated. For both, the Henry Hub natural gas price was anchored at $\$ 3.50 /$ Mcf for the life of the project; however, the basis differential was modeled as follows.

- Scenario \#1. Basis differential remains constant at \$1.80/Mcf.

- Scenario \#2. Basis differential narrows from $\$ 1.80 /$ Mcf to $\$ 0.80 /$ Mcf, over a three-year period.

Scenario \#1 represents a limiting case. A differential of $\$ 1.80 /$ Mcf is high but represents the conditions that producers have faced of late. The $\$ 0.80 / \mathrm{Mcf}$ basis differential in Scenario \#2 represents a situation in which new pipelines are constructed, providing Powder River Basin gas access to additional markets and enabling the basis differential to return to historical levels. 


\section{SECTION 3. PERFORMANCE OF MULTI-SEAM CBM WELL COMPLETIONS IN THE POWDER RIVER BASIN}

\subsection{Background}

One of the objectives of this study is to evaluate the use and performance of currently available multi-seam completion practices for coalbed methane in the Powder River Basin. This task involved:

1. Reviewing technical papers and state commission filings on the number and types of multi-seam completions in the PRB;

2. Holding discussions with a select group of basin operators to identify and discuss their use of multi-seam completions for CBM recovery;

3. Collecting and assessing data on the performance of this technology, to the extent that basin operators were willing to disclose this data; and

4. Identifying aspects of multi-seam well completion technology requiring improvements for successful application to the Powder River Basin.

In addition, ARI staff met with basin operators to: (1) establish their perceived value and need for improved multi-seam completion technology; and, (2) gain an 'expression of interest' with respect to participating with DOE/NETL in potential $\mathrm{R} \& \mathrm{D} /$ field tests of an improved version of this technology appropriate to the coal seams of the Powder River Basin.

\subsection{Overview of CBM Well Completions}

The dominant well completion method for coalbed methane wells in the PRB is open-hole, single zone completion. As shown in Figures 3-1 and 3-2, this method provides a low cost, relatively simple access to a coal seam. In brief, the completion procedure is:

- Set surface casing to 60 feet or 10 percent of the well depth, 
- Drill into the top of 2 to 3 feet of the target coal seams, using a light mud system,

- Run and cement casing; then drill out and under-ream the coal, and

- Enhance the coal, primarily to clean the coal face and remove near wellbore damage using injection and circulation of high rates of water.

While using single-zone (or single seam) well completion technology is relatively simple, it has a number of limitations:

- It bypasses the numerous thin (less than 20 feet) coal seams in the basin, as illustrated in Figure 3-3;

- It leads to the drilling of a much larger number of CBM wells, with increased capital costs and land disturbance; and

- It causes large areas of the basin to remain uneconomic, particularly when the basis differential is high and because of the relatively high gas gathering costs in the Powder River Basin. 


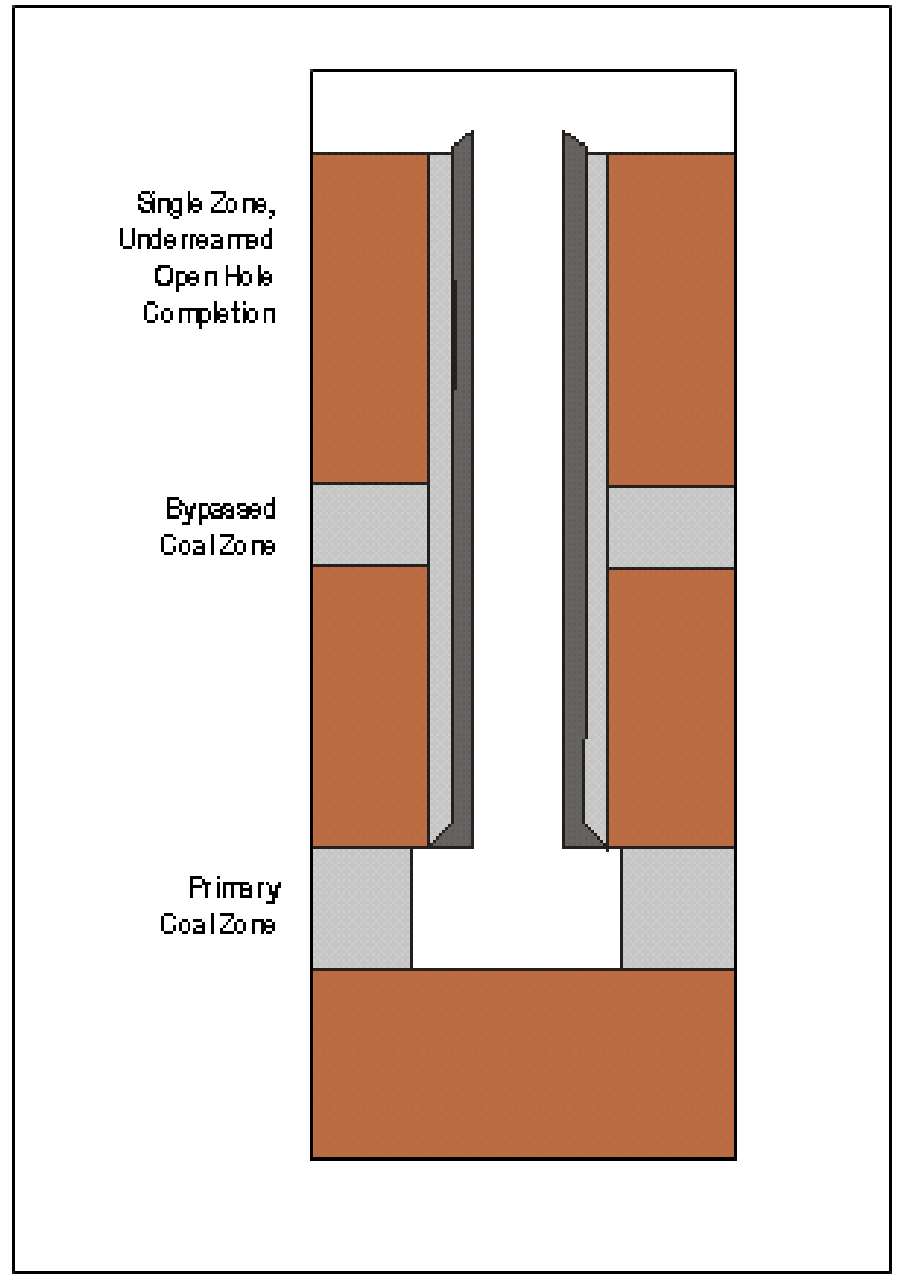

Figure 3-1. Typical CBH Well Completion Practice, Powder River Basin.

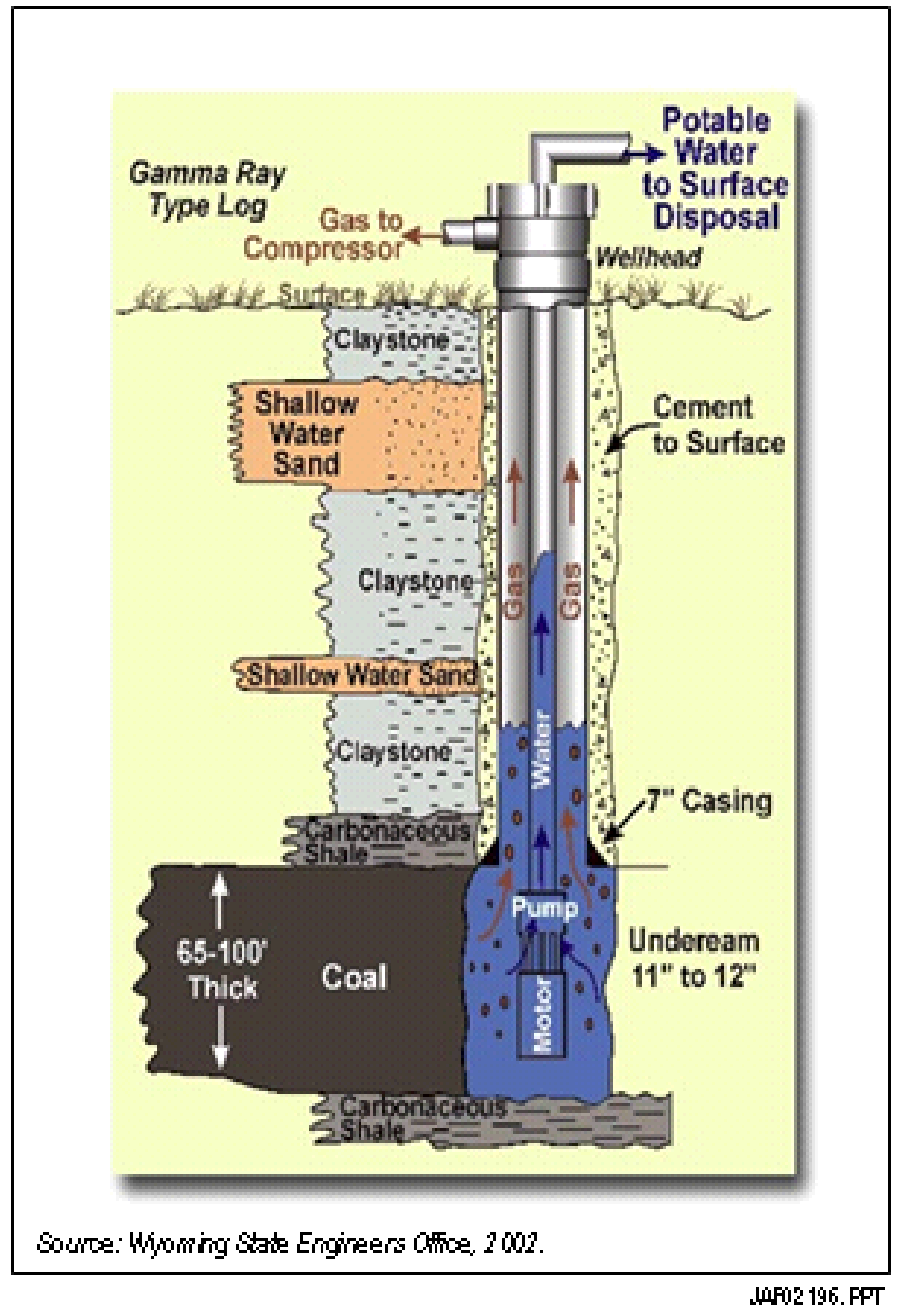

Figure 3-2 Single-Seam Coalbed Hethane Well, Powder River Basin. 


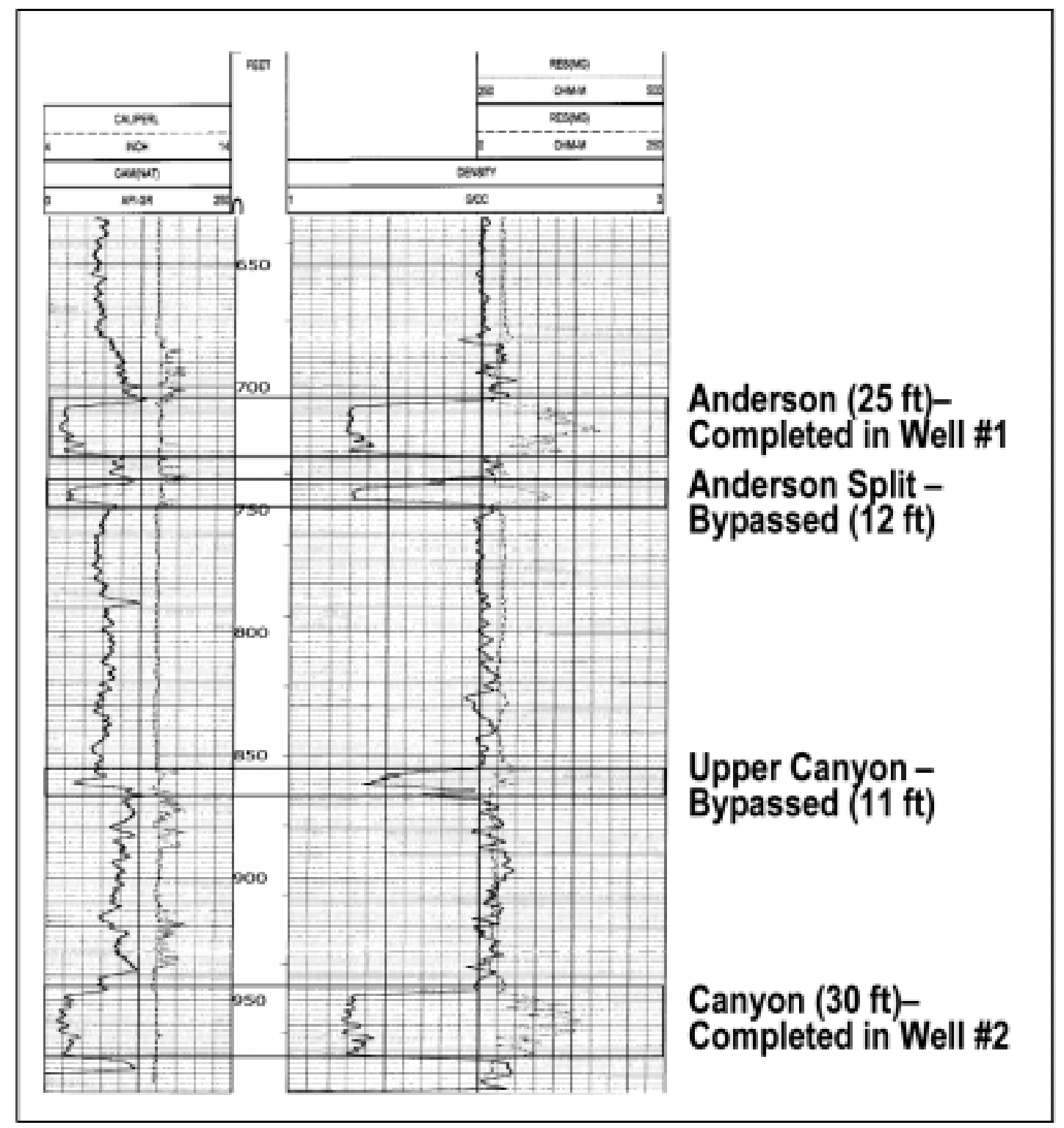

JAF02189.PPI

Coals less than 20 feet thick are not completed.

Figure 3-3. Well Log Showing Typical Fort Union Stratigraphy.

A striking illustration of these problems is the analytical map showing the large areas of the basin that are currently uneconomic or only marginally economic to develop with current single-seam well completion technology (Figure 3-4). This map was submitted to the State of Wyoming by one of the basin's main CBM operators. It dramatically illustrates, for the northern portion of the basin where this operator is active, the critical need for multi-seam well completion technology. 
Several options adapted from other CBM basins exist for multi-seam well completion technology, as illustrated in Figures 3-5 and 3-6.

- In the first option, the approach is to complete two (or more) coal seams as open-hole, and then hang a perforated steel liner across the open-hole interval. A variant on this option is to hang a PVC liner, and then under-ream the liner to assure access to the coal.

- In the second option, the approach is to drill and case across the coal, and then perforate the casing to gain access to the multiple seams.

- The third option is to use a combination of the above. The deepest coal is completed open-hole; casing is set and the up-hole coals are perforated.

The problem is that these relatively straight forward applications of multi-seam well completion technology have not proven to be successful in the Powder River Basin. In many cases, a multi-seam well produces less than a single-seam well because of damage to the coal. Additional discussion of this situation follows. 


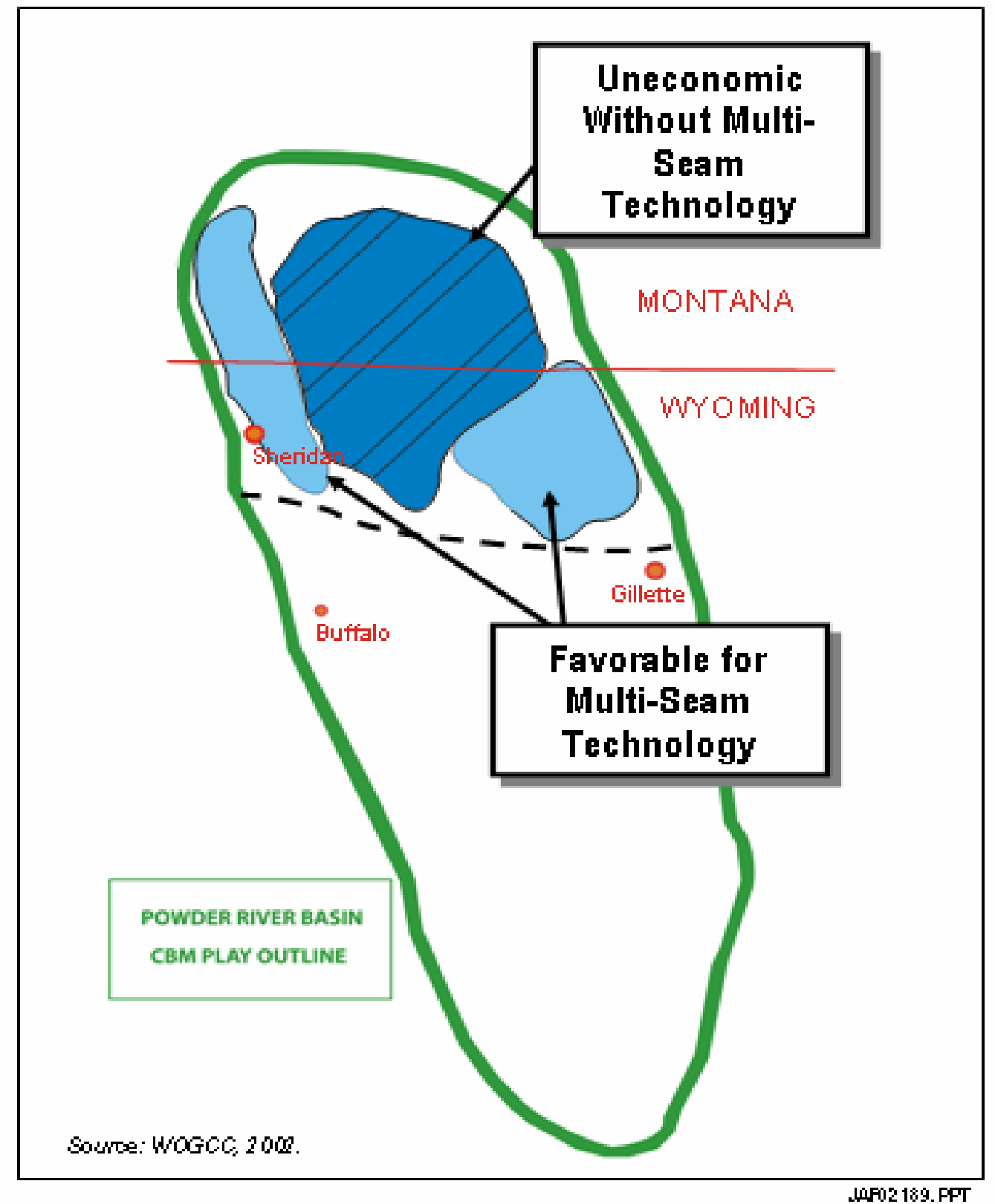

Figure 3-4. Map Submitted by Powder River Basin Operator(s) Showing Areas Where MSC Technology is Vital for Future CBM Development. 


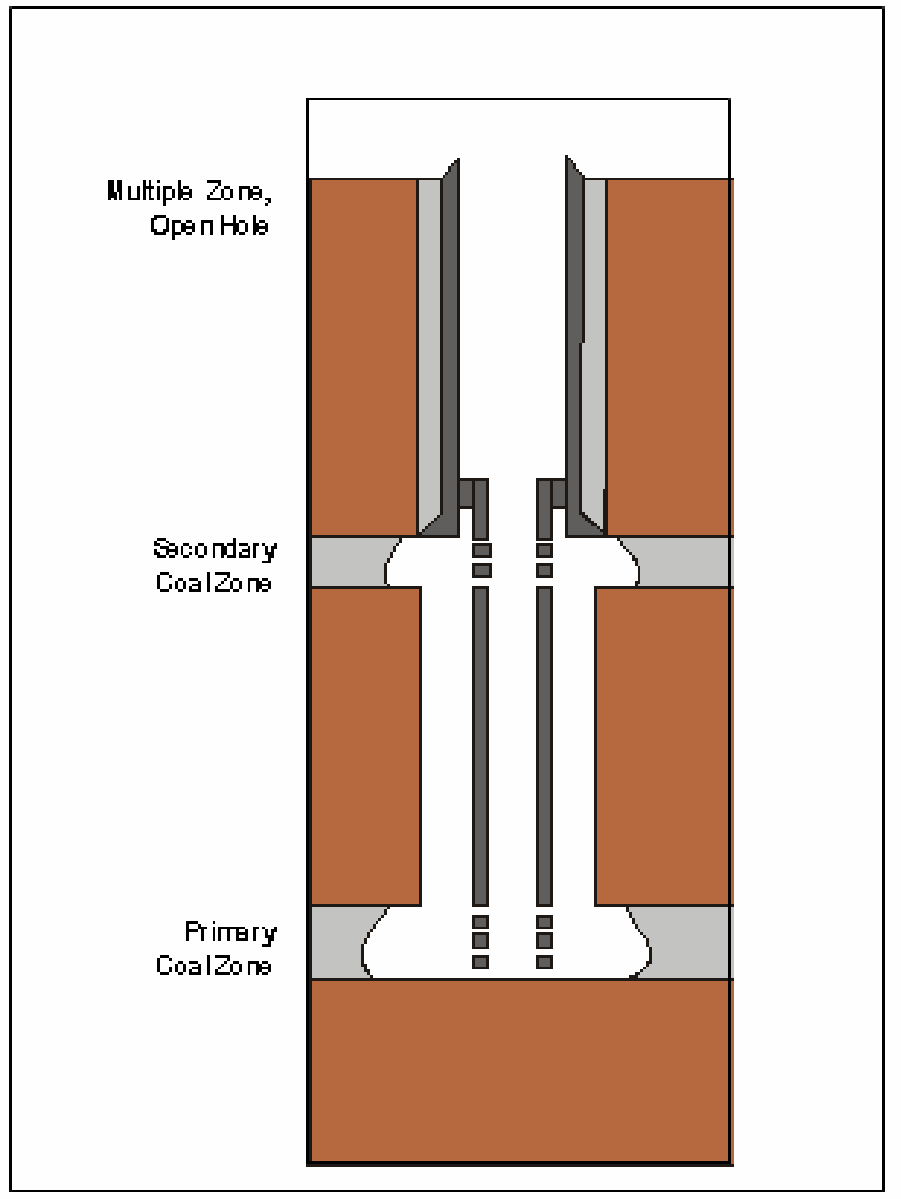

Figure 35. Multi-Seam Completion Option 1. Coals Áre Completed Open Hole; Perforated Ste el or PVC Liner ls Hung Across the Open Hole Interral.

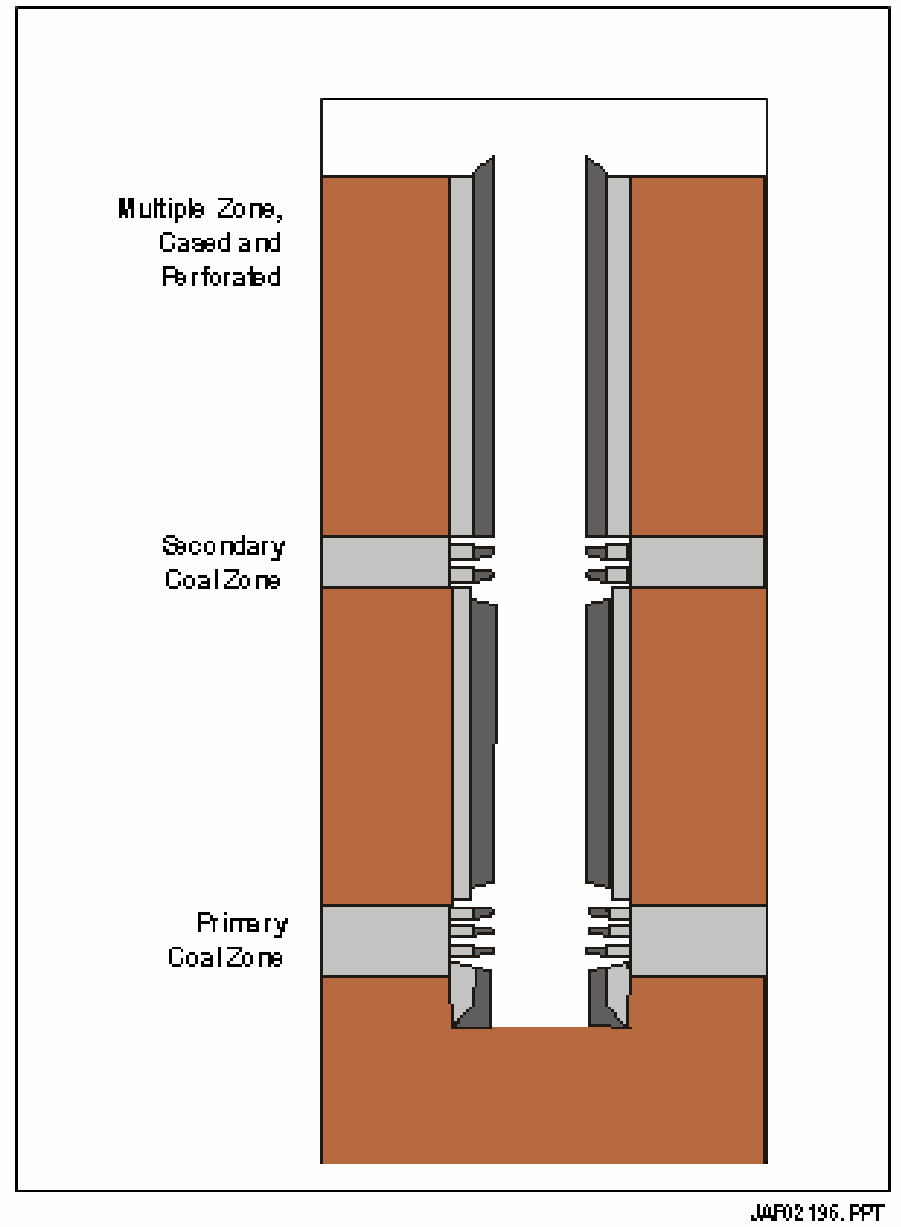

Figure 36. Hulti-Seam Completion Option 2 Entire Coal Interval is Drilled and Cased; Then Perforated to Gain Access to Coal Seams. 


\subsection{Field Case Studies}

To better understand the performance and problems with this completion strategy, three significant multi-seam CBM well completion projects in the PRB were examined. These projects are located in distinct areas in the northern Wyoming portion of the Powder River Basin (Figure 3-7). They represent the current state of multi-seam well completion technology and performance in the basin.

\subsubsection{Methodology}

Production data from the wells in each project were collected and aggregated using "time-zero" plots. From this, the average daily rate (production / actual days on) and cumulative monthly recovery are calculated for each well and then averaged to create a series of typical CBM wells for the project. The single-seam completions serve as the control wells for each project, establishing a baseline of expected production from each coal seam. The performance of multi-seam well completions (producing from these same coal seams) is established using this control set of single-seam wells.

In all three field case studies, the single-seam CBM wells are completed openhole. Casing is set just above the coal interval and the coal itself is underreamed. After flushing the coal with high rates of injected water, the CBM well is placed on production. For the multi-seam wells, the lowest coal (the primary target) is completed open-hole. Shallower seams are then accessed through perforations in the casing.

In an ideal multi-seam well, all completed zones would contribute their full potential to CBM production. Formation damage and ineffective perforation during completion, however, appear to limit production mainly to the open-hole primary seam, which itself appears to be often damaged.

The data for the three field case studies were assembled from publicly available state records and data systems (WOGCC, 2003). 


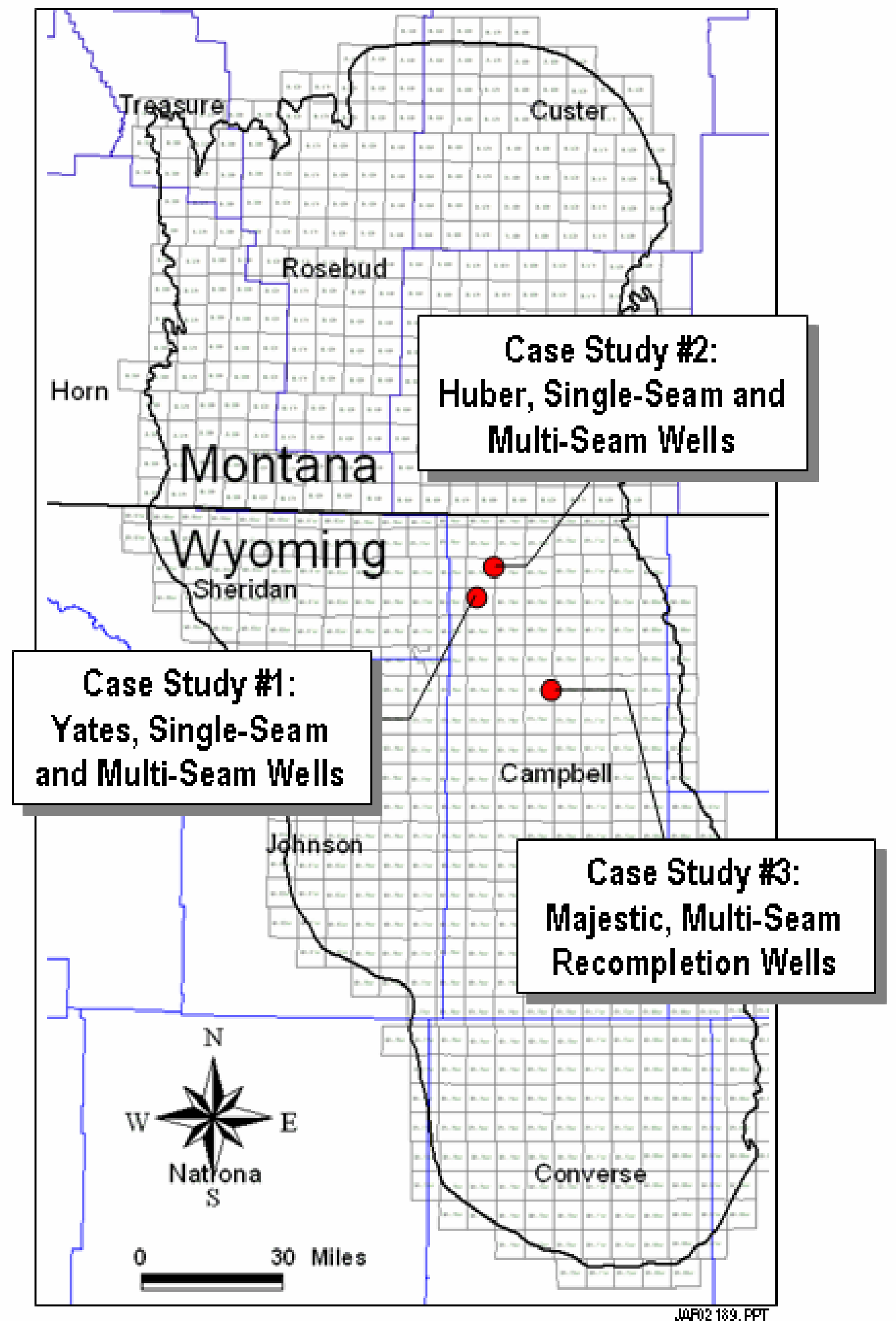

Figure 3-7. Location Map for Multi-Seam Case Studies. 


\subsubsection{Case Study \#1}

Study Purpose and Wells. Case Study \#1 involves a side-by-side comparison of the performance of nine single-seam completed Canyon coal wells and five multiseam completed Canyon, Cook and Wall coal wells. All of the wells are in S.16 of T55N R75W, providing excellent geologic and reservoir uniformity to the comparison of performance.

The wells are operated by Yates Petroleum, one of the Powder River Basin's larger and technically strong operators. The Case Study \#1 field site is located in the north-central portion of the basin, as shown in Figure 3-7. The location of the nine single-seam Canyon wells and the five multi-seam Canyon-Cook-Wall wells are shown in Figure 3-8.

Target Coal Seams. The main target, the Canyon seam, is a 30 to 40 foot coal at 400 to 500 feet of depth. The Cook seam (called Lower Canyon by the operator) in this area is a 40 foot coal at 700 to 750 feet of depth. The Wall seam is a 25 foot coal at 800 feet of depth. Ideally, producing the Cook and Wall seams with the Canyon seam, a package of nearly 100 feet of net coal would lead to a well with gas flow rates and reserves about three times higher than producing the Canyon seam alone.

Single-Seam Well Completion Strategy and Performance. The nine single-seam Canyon wells are completed as open-hole, single-seam wells, as shown for one of the case study wells, the Spotted Horse CS State \#13 (Figure 3-9). These wells are moderate CBM producers, having recovered 54 MMcf of gas during their first year on line and $86 \mathrm{MMcf}$ during their first 18 months of production, on average. The wells are currently producing at $184 \mathrm{Mcfd}$, on average. This set of wells provides the control set against which current multi-seam well completion technology is judged for this area of the basin. 


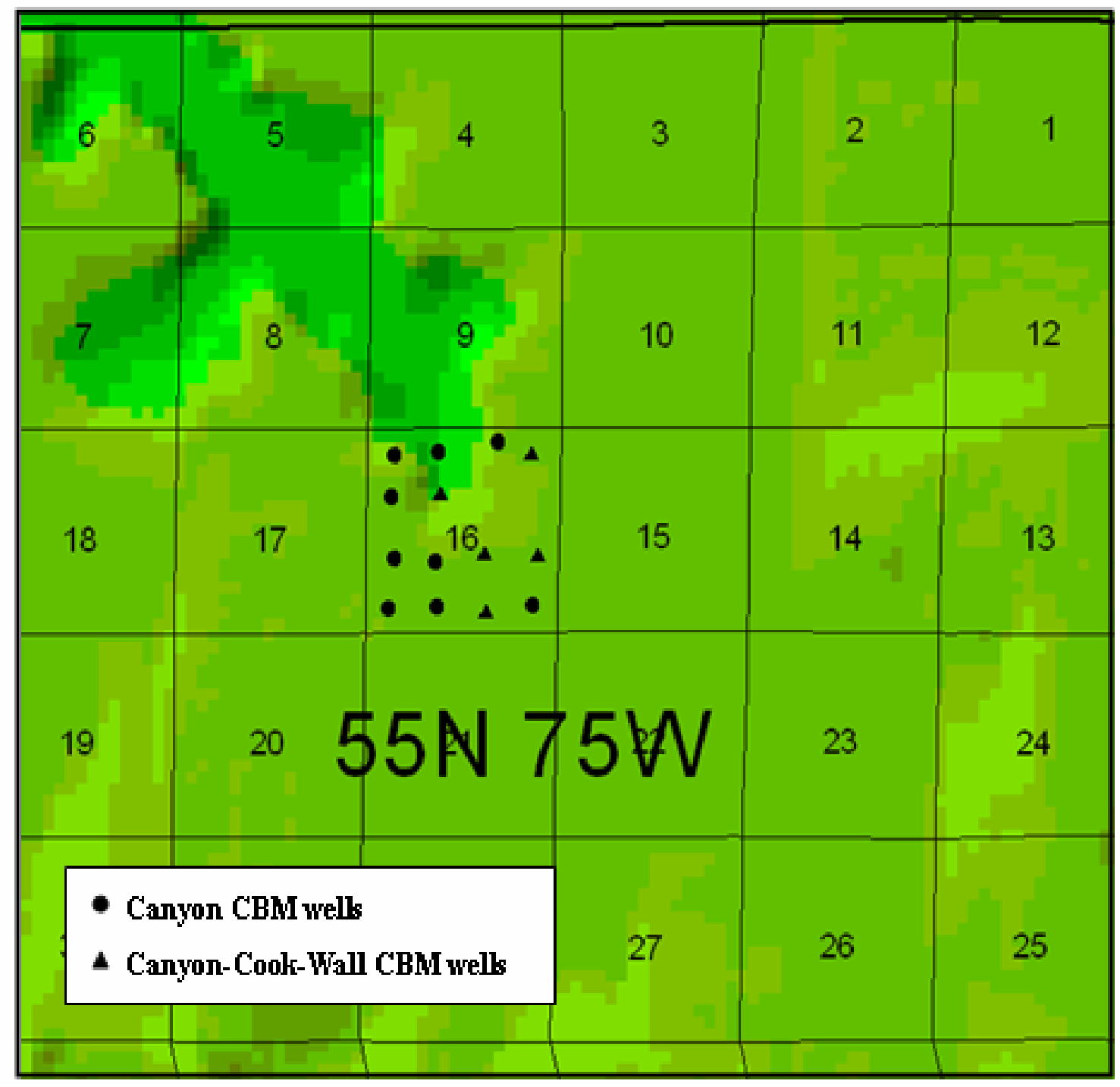

Figure 3-8. Location of Yates CBM Wells Included in Case Study \#1. 


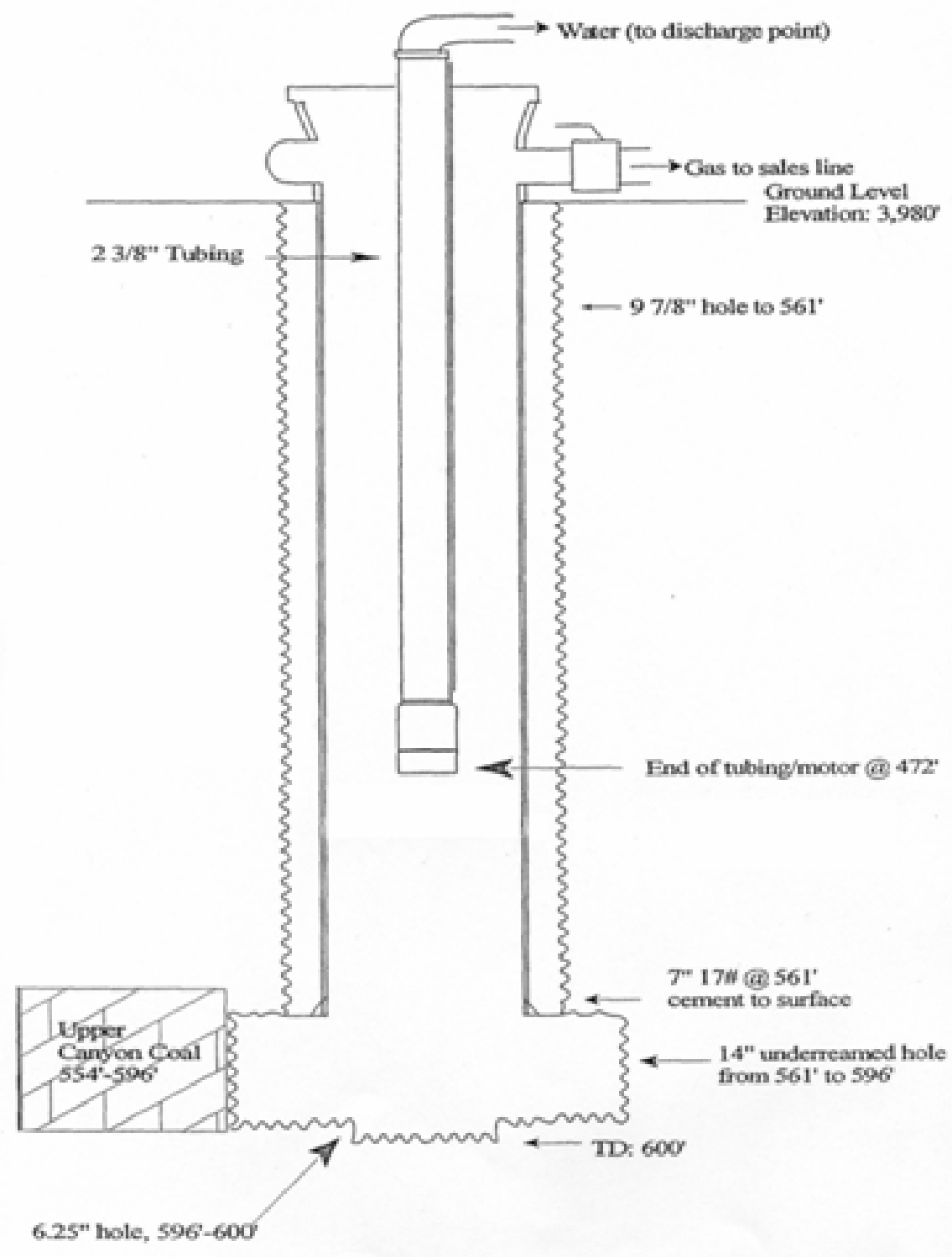

Soute: WOGCC 200 .

Figure 3-9. Case Study \#1 Single-Seam Well.

Lowest coal is completed open-hole. 
Multi-Seam Well Completion Strategy and Performance. The five multi-seam wells are completed with the lowermost Wall coal kept open-hole and with the shallower Cook (Lower Canyon) and the main Canyon seams cased and perforated, as shown for one of the case study wells, the Spotted Horse CS State \#3, in Figure 3-10.

The performance of the five multi-seam wells has been disappointing. The cumulative gas production during their first year online is $40 \mathrm{MMcf}$ and only $72 \mathrm{MMcf}$ during their first 18 months, on average. These multi-seam wells, in spite of presumably being in contact with nearly three times as much net coal as the singleseam wells, have a lower recovery than the single-seam Canyon well, as shown in Figures 3-11 and 3-12.

Poor production from the multi-seam well is not due to slow or inefficient dewatering, as shown in Figure 3-13. Instead, the interpretation is that the application of currently available multi-seam technology has created so much damage (or is so ineffective) that it has failed to efficiently connect any additional coal to the wellbore and may have actually has damaged the performance of the main coal.

It would be instructive to return to this set of Case Study \#1 wells in about a year. This would help establish whether the recent, increasing rates of gas production for the multi-seam wells suggest some amount of cleanup of the perforated coals, or some other phenomenon. 
Table 3-1. Average Case Study \#1 Single Seam Canyon Well and Multi-Seam Canyon/Cook/Wall Well, After 12 and 18 Months of Production.

(The numbers of wells included in the average are in parentheses).

\begin{tabular}{|c|c|c|}
\hline & Single Seam Wells & Multi-Seam Wells \\
\cline { 2 - 3 } & Canyon (9) & Canyon/Cook/Wall (5) \\
\hline $\begin{array}{c}\text { Cumulative Recovery } \\
\text { (MMcf) }\end{array}$ & 54 & 40 \\
@ Month 12 & 86 & 72 \\
@ Month 18 & 184 & 134 \\
\hline Daily Rate (Mcfd) & & \\
@ Month 18 & & \\
\hline
\end{tabular}

Source: WOGCC data base, 2002. 


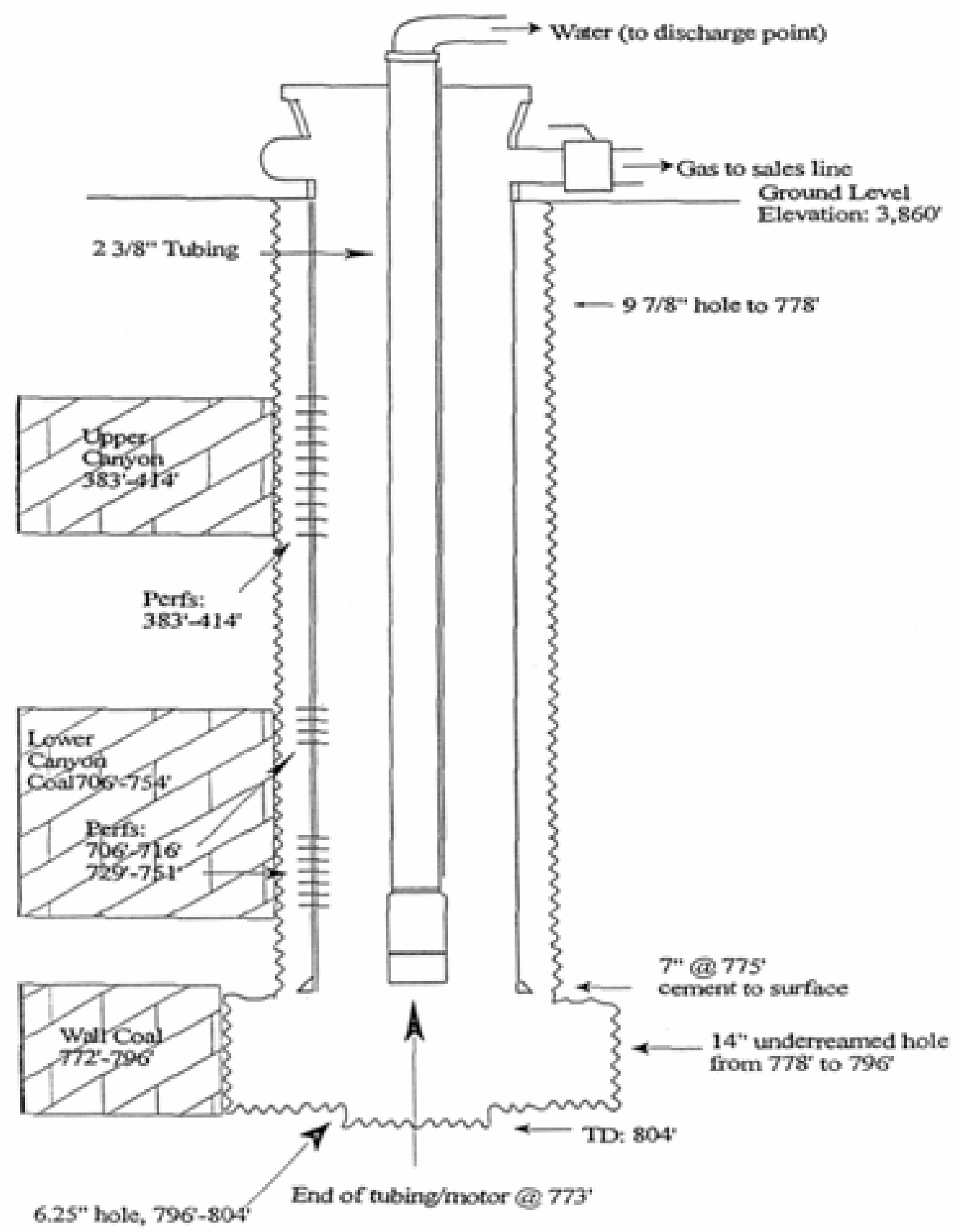

Soure: WOGCC, 200 .

Lowest Coal is completed open-hole. Access to up hole seams is through perforation.

Figure 3-10. Case Study \#1 Multi-Seam Well. 


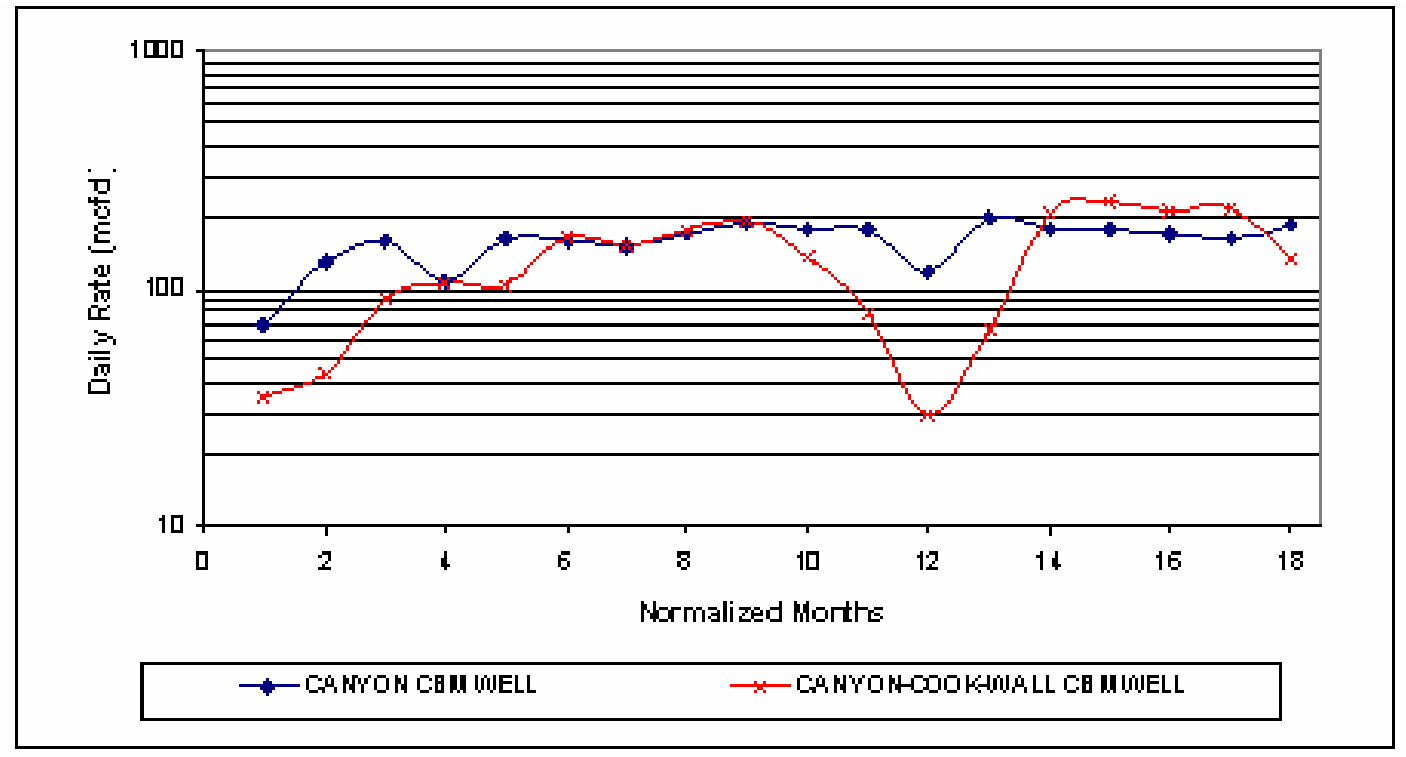

Figure 3-11. Time-Zero Production Rate for Average Single-Seam Canyon Well and Average Multi-Seam Canyon-Cook-Wall Well.

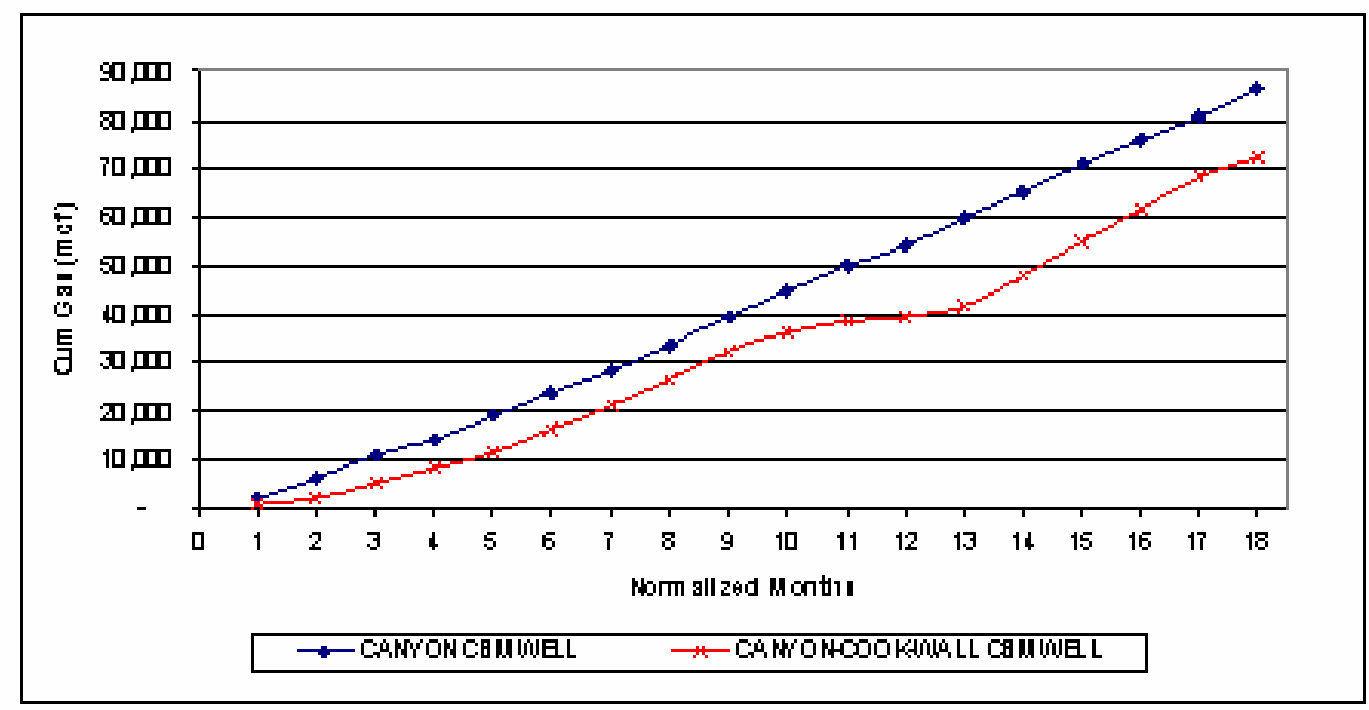

Jä02 189. FFT

Figure 3-12. Time-Zero Cumulative Production for Average Single-Seam Canyon Well and Average Multi-Seam Canyon-Cook-Wall Well. 


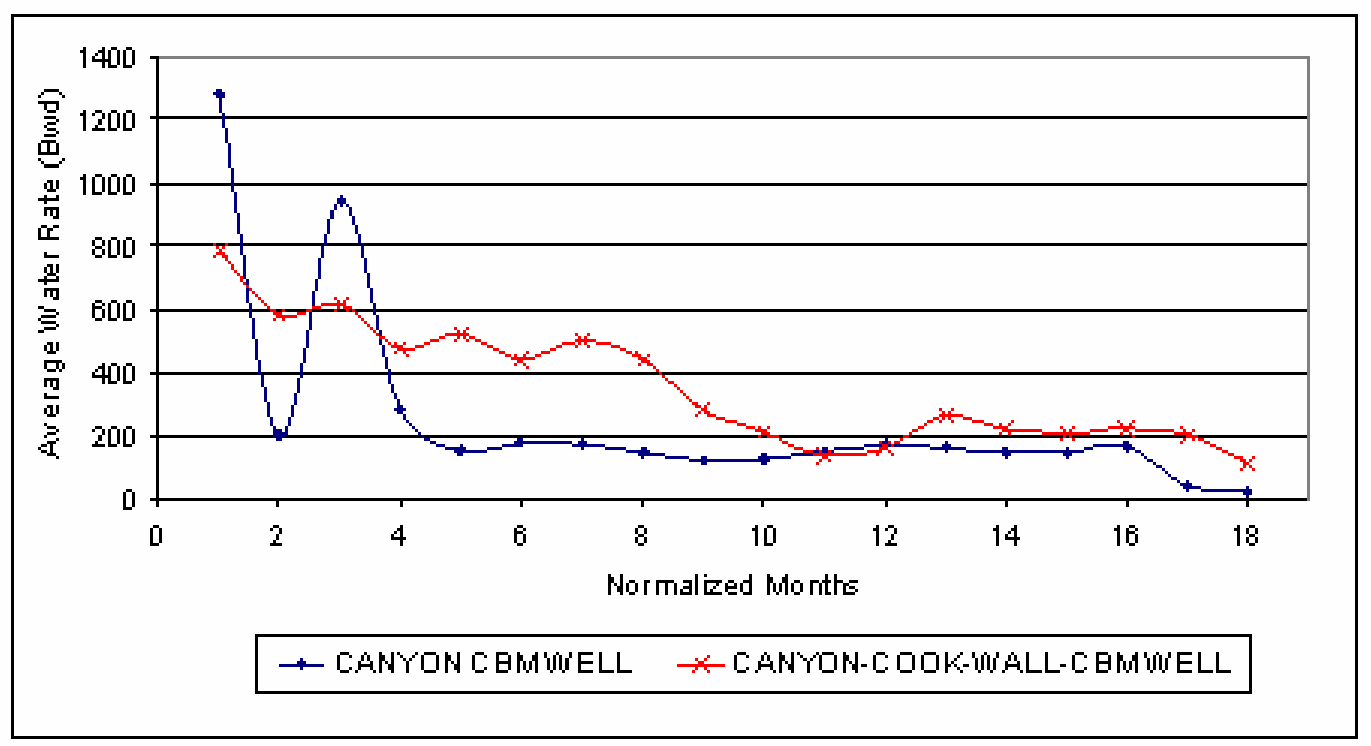

Figure 3-13. Time-Zero Water Production Rate for Average Single-Seam Canyon Well and Average Multi-Seam Canyon-Cook-Wall Well.

\subsubsection{Case Study \#2}

Study Purpose and Wells. Case Study \#2 involves a side by side comparison of 23 single-seam completed wells and 19 multi-seam completed wells. The wells are clustered in a 10 section area, in T65N, R74W and T56N R75W. The location of the Case Study \#2 CBM wells is provided in Figure 3-7 and Figure 3-14. This large well population in a relatively confined area provides a valuable data set for examining the performance of single seam and multi-seam technology.

The wells are operated by Huber, one of the largest and technically most sophisticated operators in the basin. The Case Study \#2 field site is located in the northern portion of the basin, close to the Wyoming and Montana border.

Target Coal Seams. The primary coal seam targets for the 23 single-seam completed wells are the Wall (17 wells) and the Cook ( 6 wells). In this area, the Wall coal is 15 to 30 feet thick at a depth of 680 to 825 feet. The Cook coal is 15 to 35 feet thick at a depth of 580 to 900 feet. 
The 19 multi-seam completed wells combine the Cook and Wall seams with the Canyon (Upper Cook) in 8 wells and combine the Cook and Wall seams with the Canyon and Pawnee in 11 wells. The shallower Canyon coal in this area is 30 to 35 feet thick at a depth of 240 to 550 feet. The deeper Pawnee coal is 10 to 40 feet thick at a depth of 590 to 1,010 feet.

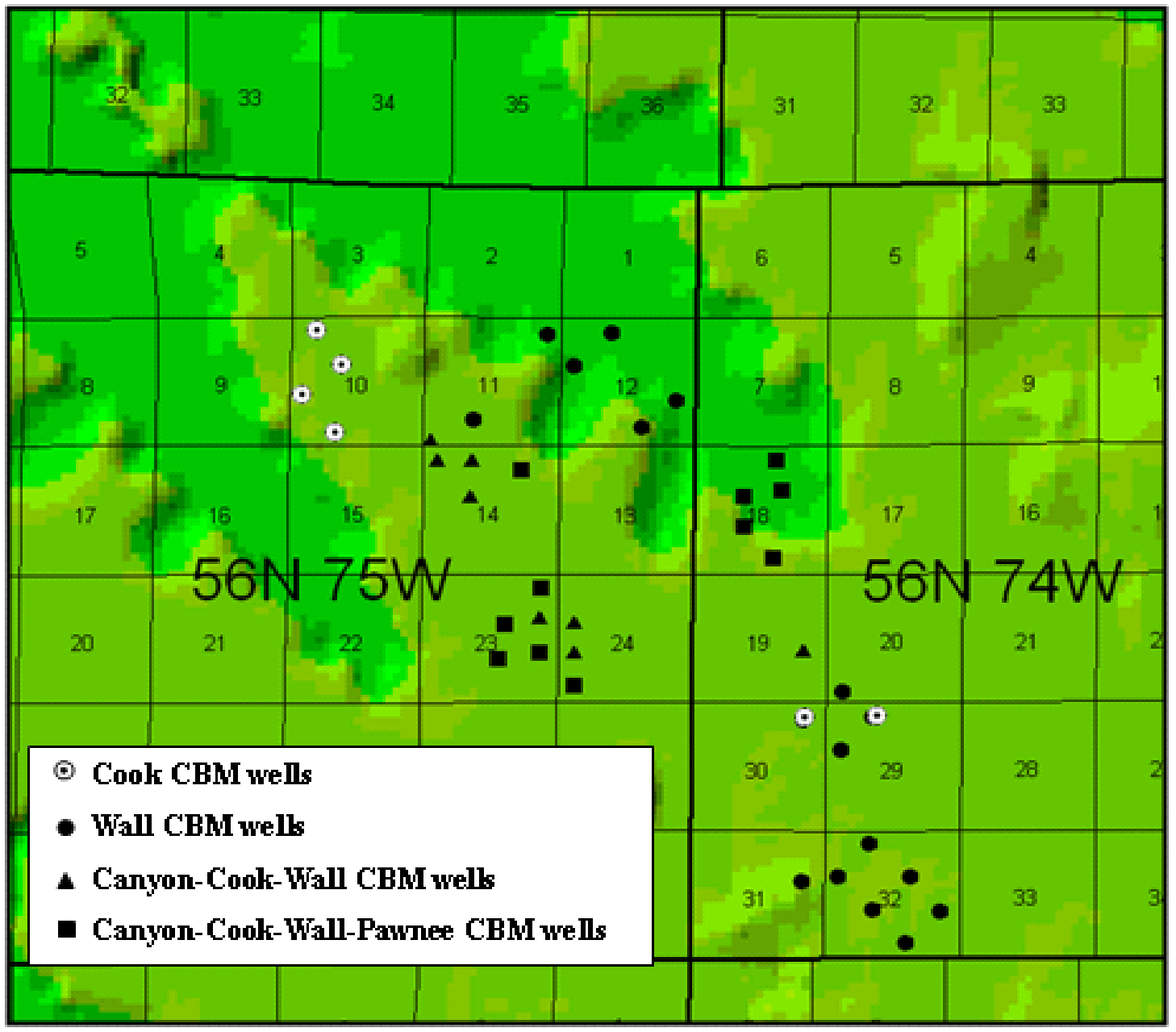

Figure 3-14. Location of Huber CBM Wells Included in Case Study \#2.

Successfully combining the Canyon, Cook and Wall (plus the Pawnee) in the multi-zone completed wells should lead, ideally, to a well with about three times as much gas production as a single-zone Wall or Cook completion. 
Single-Seam Well Completion Strategy and Performance. The single-zone Wall and Cook wells are completed open hole. After the first eight months online, the average Wall CBM well has recovered $37 \mathrm{MMcf}$ and is producing $281 \mathrm{Mcfd}$; the average Cook CBM well has recovered $29 \mathrm{MMcf}$ and is producing $144 \mathrm{Mcfd}$. Production continues to increase for both sets of wells and dewatering continues.

Multi-Seam Well Completion Strategy and Performance. The multi-zone wells are completed with the lower-most coal kept open-hole and the shallower coals cased and perforated. The performance of the multi-zone wells compared to the single-seam wells is extremely disappointing, as shown on Figures 3-15 and 3-16. Early-time data suggest that limited dewatering is not to blame for poor well performance, Figure 3-17.

- The average three-zone-Wall, Cook and Canyon-well has recovered only $16 \mathrm{MMcf}$ and is producing $107 \mathrm{Mcfd}$ after eight months online. Even if the Canyon seam made no contribution, this well should have recovered about $66 \mathrm{MMcf}$ and should be producing $425 \mathrm{Mcfd}$, based on comparable single seam well performances for the Wall and the Cook seams. (After 16 months online, the production rate for the average three-zone well is still only about 160 Mcfd.)

- The average four-zone-Pawnee, Wall, Cook and Canyon-well has recovered only $20 \mathrm{MMcf}$ and is producing at $95 \mathrm{Mcfd}$ after eight months online. (The longer term performance of the four-zone well provides some indication that the wells may be cleaning up. After 2 years online, the cumulative recovery for the four-zone well is $85 \mathrm{MMcf}$ and the production rate has increased to and remained steady at about $150 \mathrm{Mcfd}$ ).

The summary of the comparative performance of the Case Study \#2 CBM wells is provided in Table 3-2 below, after their first eight months online. 
Table 3-2. Average Case Study \#2 - Single Seam and Multi-Seam Wells, 8 Months of Production.

\begin{tabular}{|c|c|c|c|c|}
\cline { 2 - 5 } \multicolumn{1}{c|}{} & \multicolumn{2}{c|}{ Single Seam Wells } & \multicolumn{2}{c|}{ Multi-Seam Wells } \\
\cline { 2 - 5 } & Wall (17) & Cook (6) & $\begin{array}{c}\text { Canyon-Cook-Wall } \\
\text { (8) }\end{array}$ & $\begin{array}{c}\text { Canyon-Cook-Wall- } \\
\text { Pawnee (11) }\end{array}$ \\
\hline $\begin{array}{c}\text { Cumulative Recovery (MMcf) } \\
\text { @ Month 8 }\end{array}$ & 37 & 29 & 16 & 20 \\
\hline Daily Rate (Mcfd) @ Month 8 & 281 & 144 & 107 & 95 \\
\hline
\end{tabular}

The numbers of wells included in time-zero averages are in parentheses.

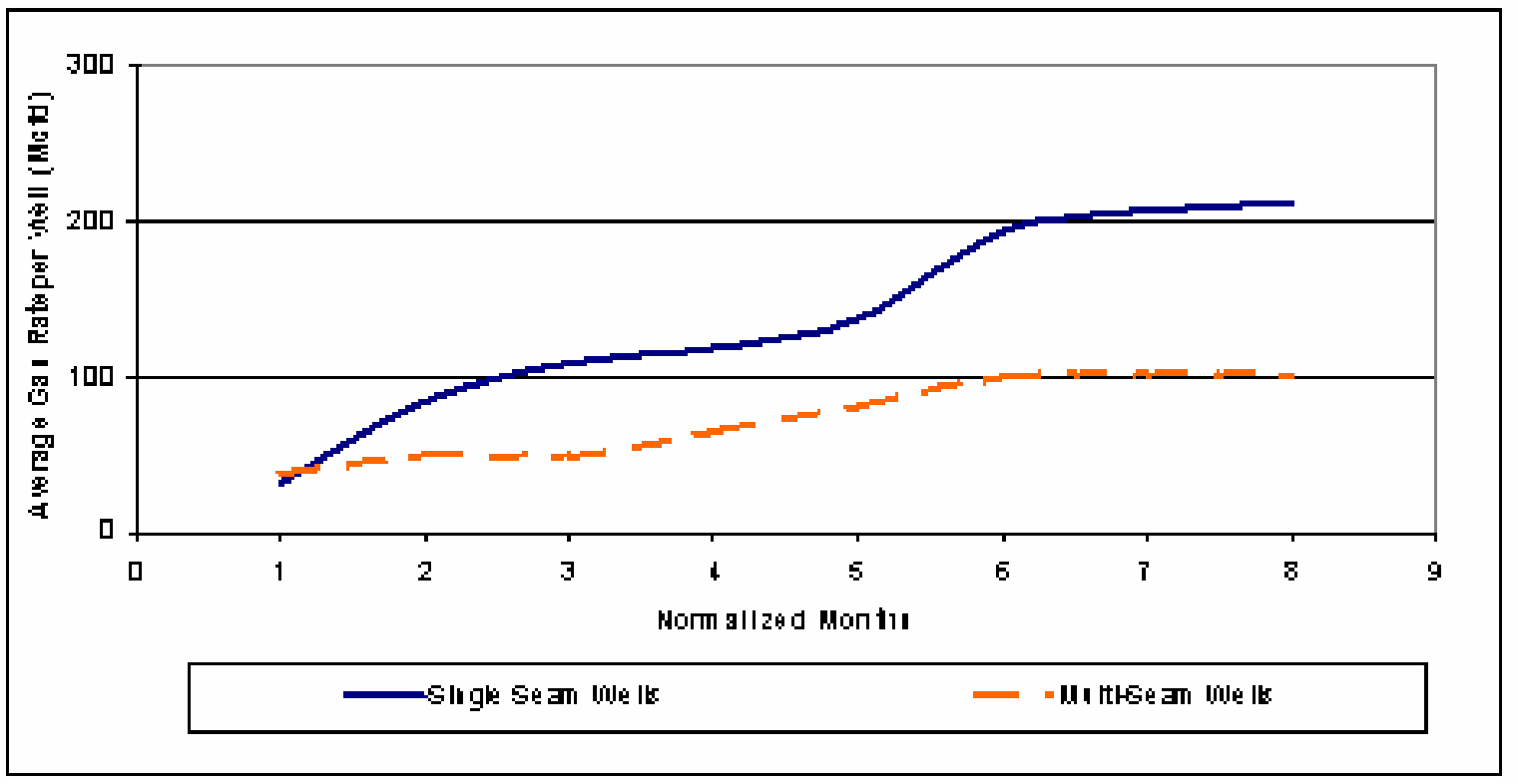

Figure 3-15. Production Rate for Average Single-Seam Wells (Cook, Wall) and Average Multi-Seam Wells (Canyon-Cook-Wall, Canyon-Cook-Wall-Pawnee). 


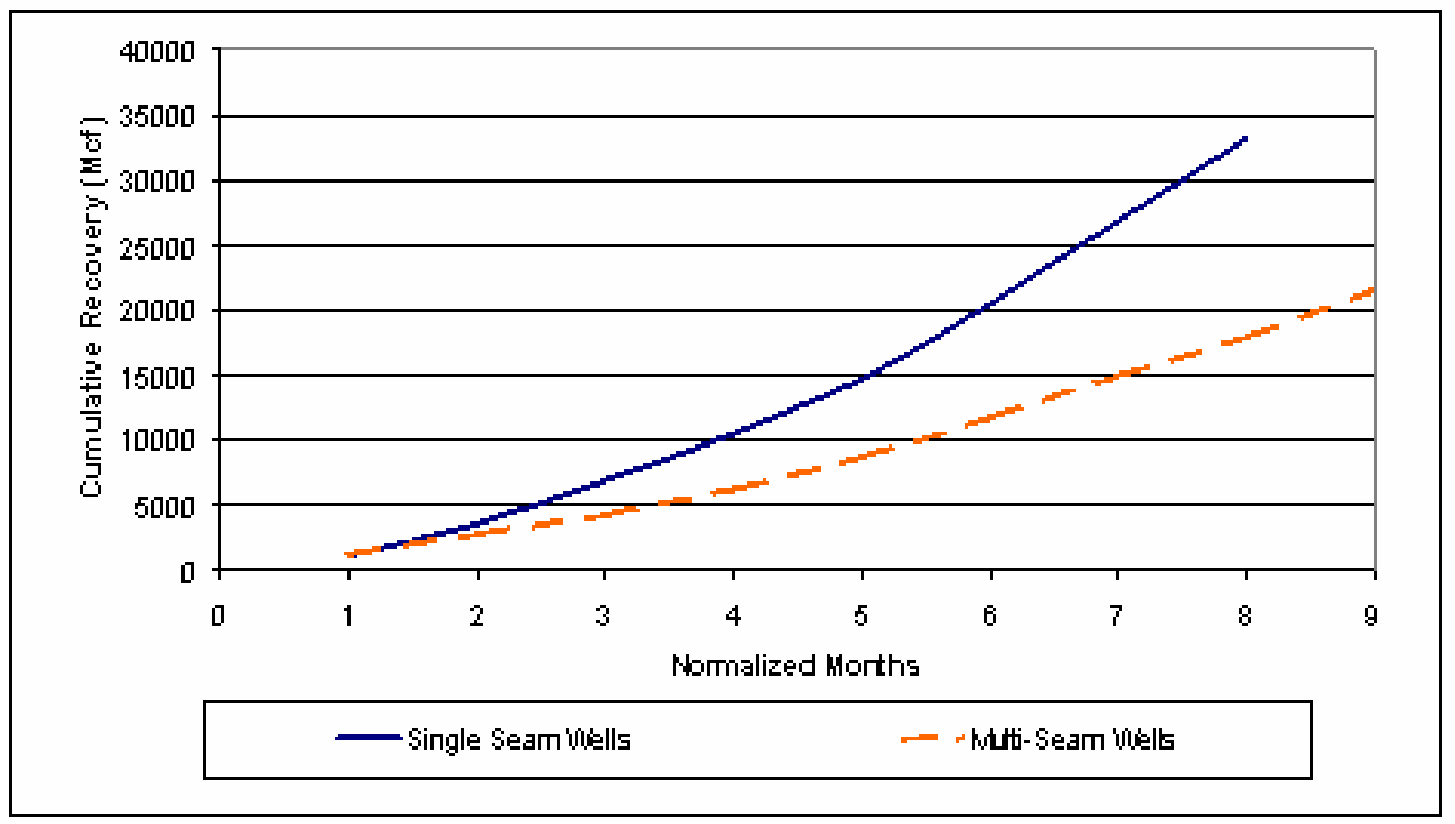

Figure 3-16. Cumulative Production for Average Single-Seam Wells (Cook, Wall) and Average Multi-Seam Wells (Canyon-Cook-Wall, Canyon-Cook-Wall-Pawnee).

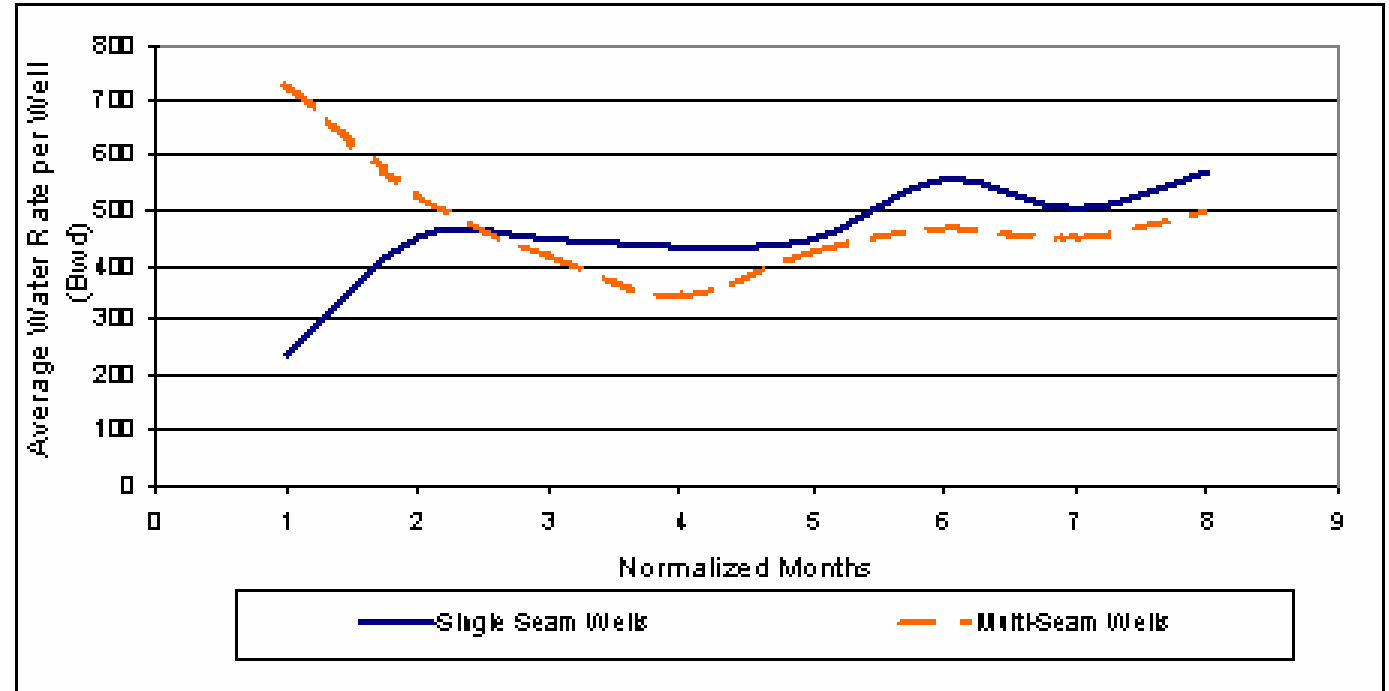

Figure 3-17. Water Production Rate for Average Single-Seam Wells (Cook, Wall) and Average Multi-Seam Wells (Canyon-Cook-Wall, Canyon-Cook-Wall-Pawnee). 


\subsubsection{Case Study \#3}

Study Purpose and Wells. Case Study \#3 involves the application of multi-seam technology to add additional coals, the Cook and the Anderson seams, to five existing single-seam completed CBM wells, initially completed in the Canyon coal. Three of the wells are in S.11 and S.12 of T52N R72W and two of the wells are in an adjoining area, S.18 and S.19 of T52N R73W.

The wells are operated by Majestic Petroleum LLC, a small independent operator in the Powder River Basin. The Case Study \#3 field site is located in the eastcentral portion of the basin, as shown in Figure 3-7 and Figure 3-18.

Target Coal Seams. The main target, the Canyon seam, is a 60 to 85 foot coal at 330 to 460 feet of depth. The shallower Anderson seam has 35 to 45 net feet of coal at a depth of 140 to 280 feet. Successfully adding and producing the Anderson coal seam with the Canyon would, ideally, lead to a well with about 50 percent higher gas production rates and reserves as a Canyon single-zone completion.

Single-Seam Well Completion Strategy and Performance. The initial completions in the five Canyon coal seam wells were open-hole single-seam. After their first three years of operation, the five Canyon wells had recovered 168 MMcf of CBM (on average) and were still producing at about 100 Mcfd.

Multi-Seam Well Completion Strategy and Performance. In August 2001, with gas production in modest decline (about 2 percent per month), the operator recompleted these wells to add the Anderson coal seam and began reporting the data on a commingled basis. For the five multi-zone recompletions, initial results were disappointing as production through the end of 2001 was less than expected from the Canyon seam alone. Through 2002, gas production returned to an average of 100 Mcfd early in 2002, and has fluctuated between 100 and 125 Mcfd during the past year.

The latest performance of these recompleted, multi-seam wells is more encouraging, with the Anderson seam making an estimated contribution of about 40 
to 50 Mcfd. However, this is considerably less than would be expected from an efficiently completed Anderson coal well in this area.

At the end of 18 months online, the Anderson well has recovered an estimated 15 MMcf, as shown in Figure 3-19. (These estimates assume the continuation of the 2 percent monthly gas production decline rate for the Canyon single-seam completion.) After 18 months, the typical Anderson CBM wells in this township, with the same coal thickness as the recompleted wells, would have recovered $36 \mathrm{MMcf}$, more than twice actual performance.

The summary performance of the Case Study \#3 CBM wells is provided in Table 3-3 below, in MMcf of cumulative recovery for the average well:

Table 3-3. Average Case Study \#3 - Single-Seam and Multi-Seam Recompleted Wells.

\begin{tabular}{|c|c|c|c|}
\hline $\begin{array}{c}\text { Cumulative Recovery } \\
\text { (MMcf) }\end{array}$ & $\begin{array}{c}\text { Canyon Single-Seam } \\
\text { Completion (5) }\end{array}$ & $\begin{array}{c}\text { Anderson Multi-Zone } \\
\text { Recompletion (5) }\end{array}$ & $\begin{array}{c}\text { Total Well } \\
\text { Performance (5) }\end{array}$ \\
\hline First 3 Years & 168 & - & 168 \\
\hline Last 18 Months & 44 & 15 & 59 \\
\hline Total to Date & 212 & 15 & 227 \\
\hline
\end{tabular}




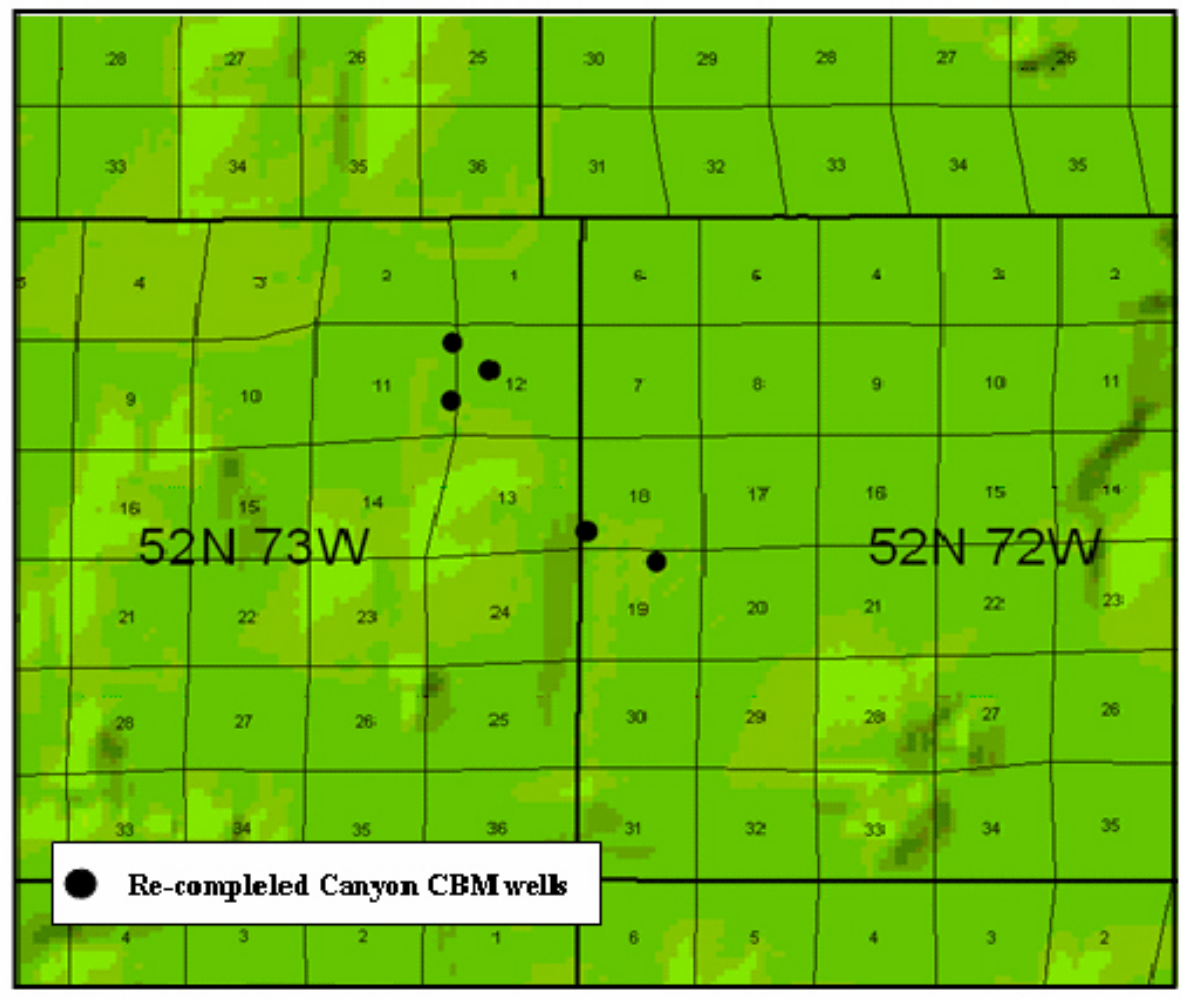

Figure 3-18. Location of Majestic CBM Wells Included in Case Study \#3.

\subsubsection{Summary}

Attempts at effective multi-seam CBM completions in the Powder River Basin have met with disappointing results, thus far. Most often, the secondary seams simply fail to contribute to production. In a few cases, the extra completions actually cause the overall CBM production rates to drop below that expected from the primary seam. These problems must be overcome with an alternate strategy and approach to multiple-seam well completion technology. Successful application of MSC technology would enable the vast coalbed methane resource residing in subeconomic thick and thin coal seams in the Powder River Basin to be added to the nation's natural gas reserves with fewer wells and less environmental disturbance. 


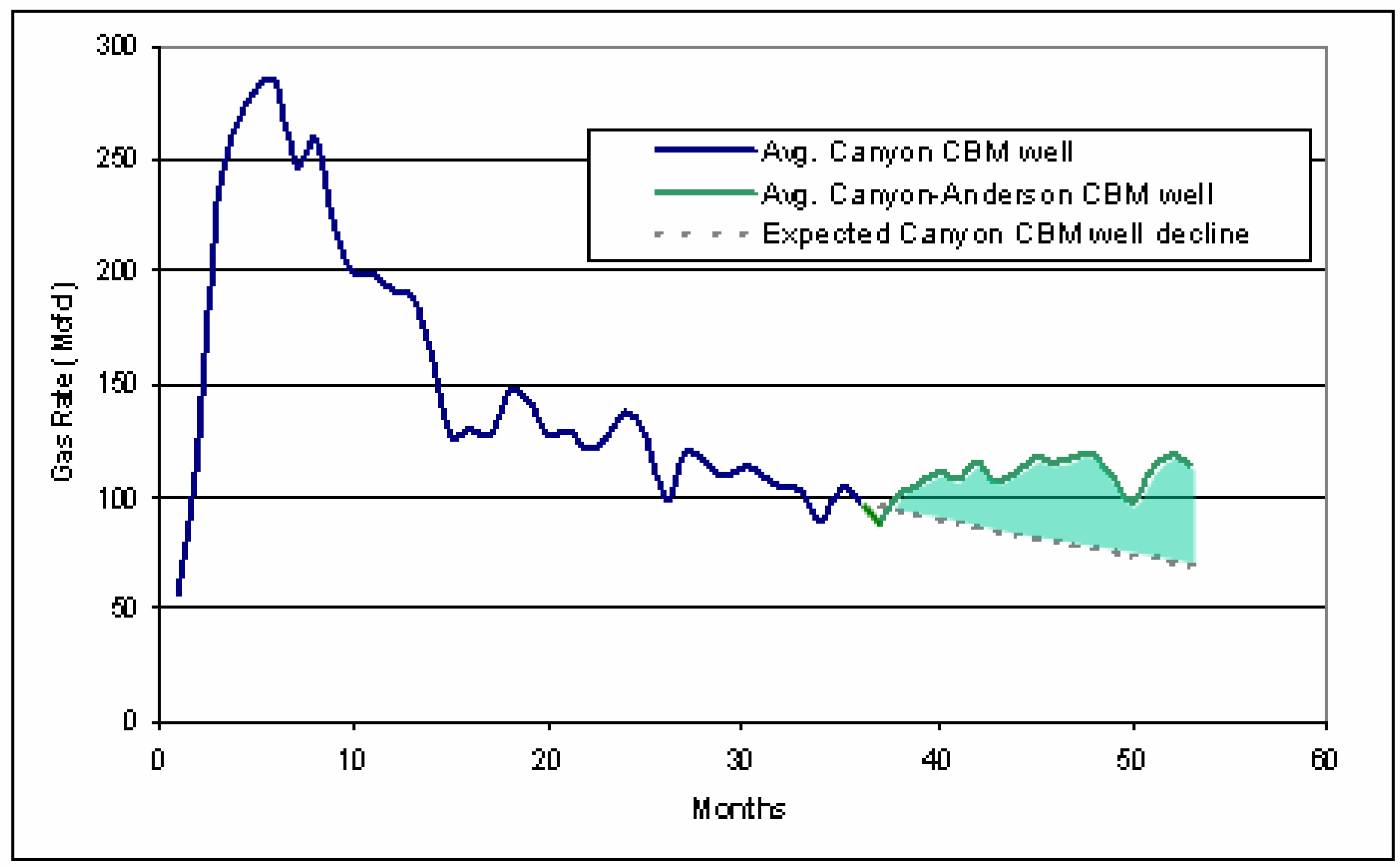

L4F2 196. FPT

Figure 3-19. Average Case Study H3 Canyon CBH Well and lts Recompletion. (The Shaded Area Betwe en Canyon-Anderson Production and the Expected Can yon CBH Well Decline is the Estimated Contribution of the Anderson Seam.) 


\section{SECTION 4. APPLICATION AND PERFORMANCE OF MULTI-SEAM COMPLETION TECHNOLOGY IN OTHER CBM BASINS}

\subsection{Background}

Developing and successfully applying multi-seam well completion (MSC) technology for recovering coalbed methane has long been a goal of operators and research organizations. For example, one of the initial CBM R\&D projects of the Gas Research Institute (GRI) was the Methane from Multiple Coal Seams Completion Project at the Rock Creek field research laboratory in the Warrior Basin, Alabama (Figure 4-1).

The motivation for developing multi-seam technology for completing the numerous coals in this basin was to improve the economics (breakeven price) of coalbed methane recovery in this basin, as shown in Figure 4-2. The figure shows that successful use of multiple coal seam completions would cut the costs, and thus the minimum breakeven price, for CBM in the Warrior basin by half.

The multi-seam technology being developed in the Warrior Basin was linked and dependent on advanced stimulation technology. Together, these two technologies offered the promise of nearly tripling gas recovery per well, from 200 MMcf per well with single-seam technology to $600 \mathrm{MMcf}$ per well with use of multi-seam technology and advanced hydraulic fracturing (Figure 4-3).

The overall objective was to develop multi-seam completion technology and practices that could then be transferred and applied to the large CBM resource contained in the multiple, thin coal seams of the Central and Northern Appalachian basins, as shown in Figure 4-4.

The Rock Creek Field Research Project demonstrated that completing all coal seams encountered in a single well bore would result in increased per well reserves compared to single-seam completions. Consequently, multi-seam completion became the strategy of choice in all coal basins with stacked coal reservoirs. 


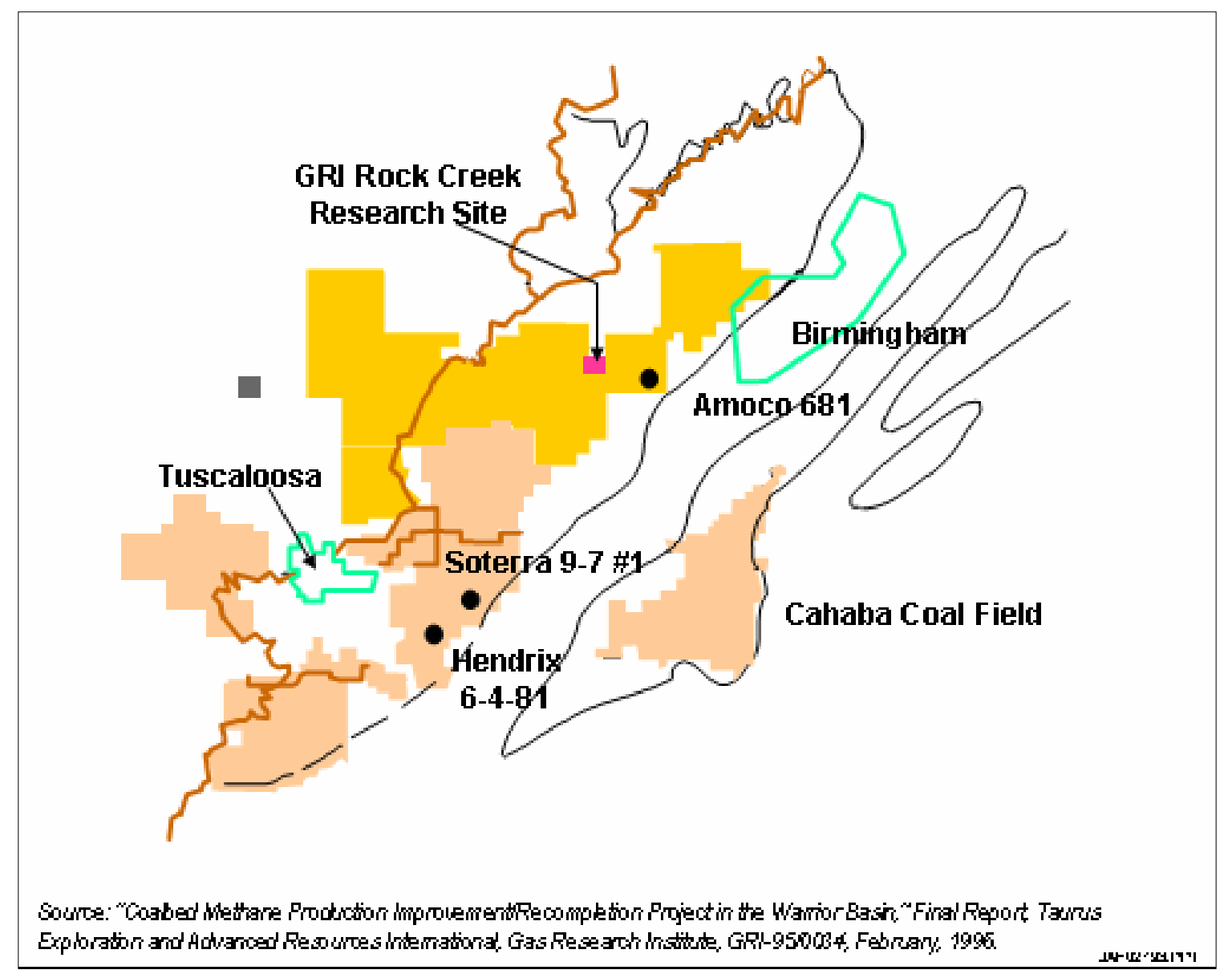

Figure 4-1. Location of the Rock Creek Field Research Site, Warrior Basin, Alabama. 


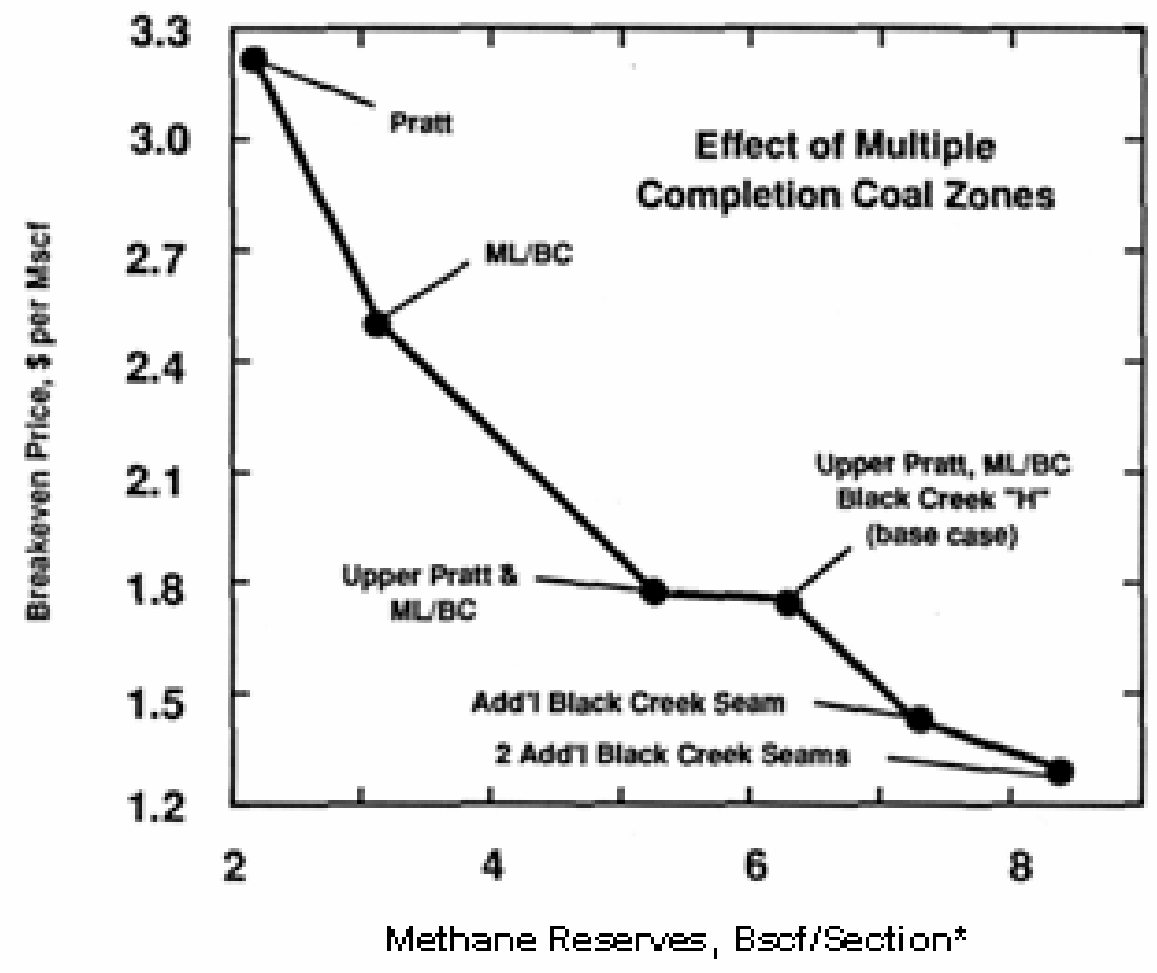

thserming 16 wells per section.

Source: "Efective Completions for Shalow coal Seams" Topical Rpoort Tauns Expbration and

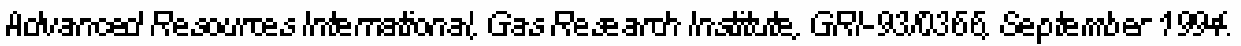

וירוד

Figure 4-2. Effect of Multiple Completion of Coal Seams on Breakeven Gas Price, Warrior Basin, Alabama. 


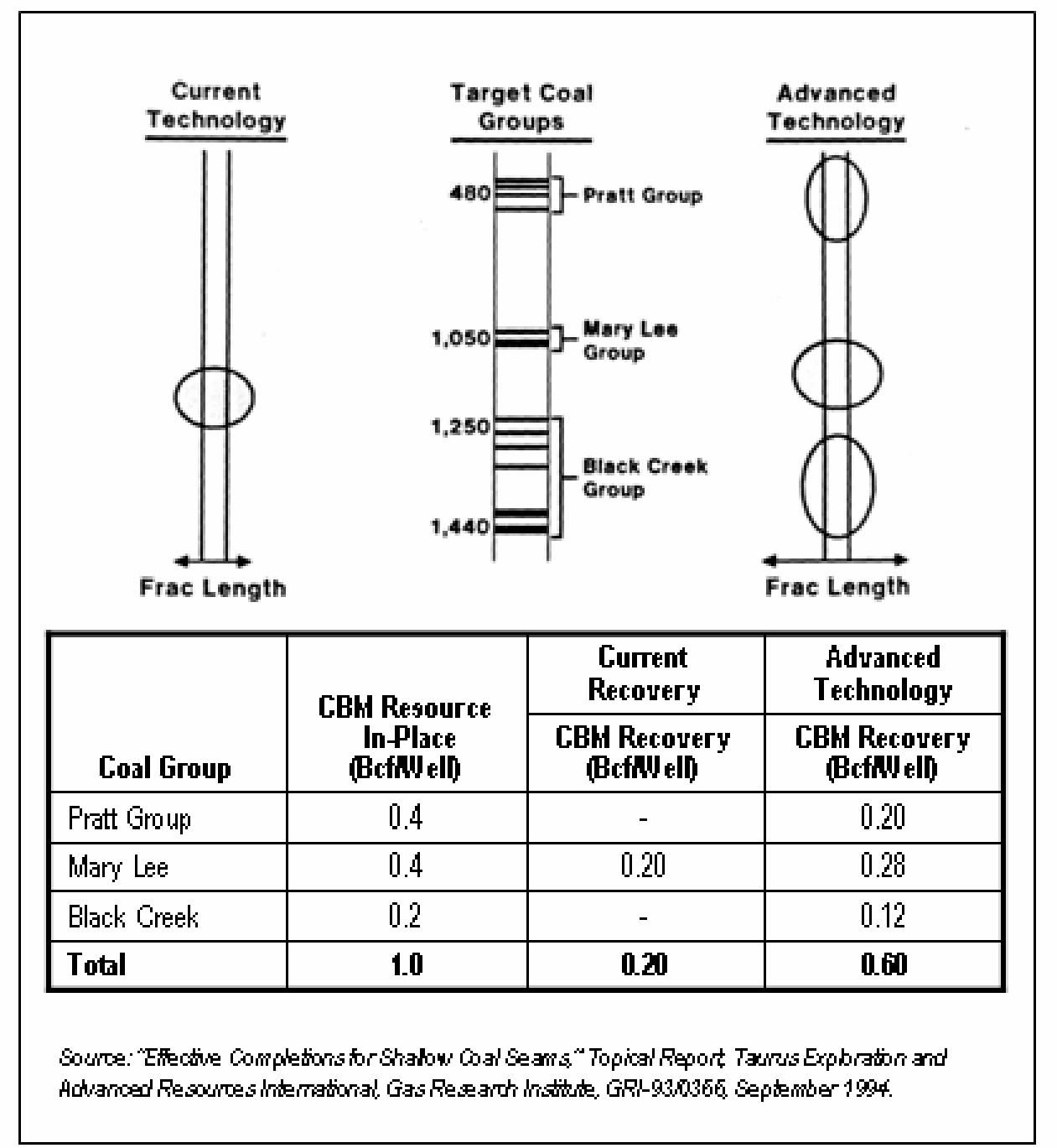

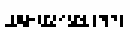

Figure 4-3. Objectives of Multi-Seam Completion Project. 

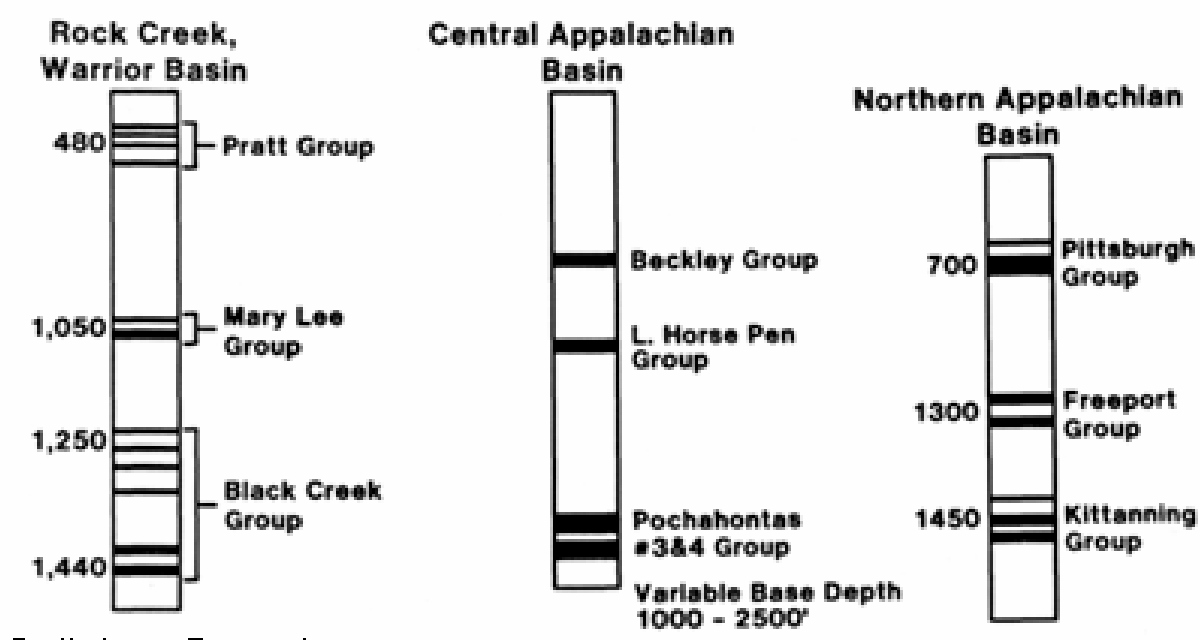

Preliminary Esonomics (Mini mum Required Wellhead Price)

\begin{tabular}{|c|c|c|c|}
\hline Single Zone & $\$ 2.50$ wicf & $\$ 3.00-\$ 4.40$ & $\$ 3.70-\$ 4.30$ \\
\hline Wulti Zone & $\$ 1.50$ wicf & $\$ 1.00-\$ 2.00$ & $\$ 2.50$ \\
\hline Gas Content & $350-500 \mathrm{ft}^{*}$ ton & $350-500+\mathrm{ft}^{*}$ ton & $200 \mathrm{ft}^{3}$ ton \\
\hline
\end{tabular}

Soure: "Efective Completions for Shalow Col Seams" Topical Report Tauss Expbration and

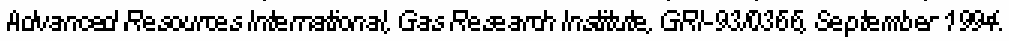

Figure 4-4. Multiple Completion Potential of Pennsylvanian Age Coals.

The Powder River Basin (PRB) may well be the only basin where single-seam well completions are the standard completion method despite the presence of multiple coal seams. However, early multi-seam completion attempts in the PRB, based on completion strategies used in other coal basins, have largely been unsuccessful in establishing commercial gas rates, as discussed in detail in Chapter 3.

To further understand why multi-seam completion methods used in other CBM plays aren't applicable to the PRB, it is useful to review the various MSC technology options and how those options have been adapted to the unique coal distribution, thickness, and reservoir properties in each CBM basin. 


\subsection{Current CBM Development Strategies}

Multi-seam well completions are used extensively in the San Juan, Warrior, Uinta and Raton basins. These basins also utilize hydraulic stimulations with sand proppant to enhance gas and water rates. (In addition to hydraulic stimulation, the dynamic open-hole cavity completion method is also used in the San Juan Basin.) The type and design of hydraulic stimulations vary considerably among the basins, reflecting differing geologic, and reservoir conditions. A summary of currently applied multi-seam completion technology in the San Juan, Raton, and Uinta, basins is provided in Appendix A.

There are two reasons why most CBM wells require a propped, hydraulic stimulation:

1. To overcome damage caused during drilling and cementing. Coal reservoirs are susceptible to invasion during well drilling and cementing. The permeable, under-pressured coals of the PRB suffer deep invasion and consequently can become severely damaged during drilling and cementing operations.

2. To better connect the well bore with the natural fracture system. Coals are typically low permeability reservoirs with vertical, natural fractures providing the primary source for permeability. A vertical well intersects relatively few vertical fractures; therefore, flow to the well bore is limited without the benefit of a propped fracture system. Coals of the PRB have high inherent permeability and associated high natural flow potential, therefore, propped hydraulic stimulations are less important in the absence of damage caused by drilling fluids and cement.

The Powder River Basin open-hole completion technology avoids exposing the coal seam to damaging drilling fluids and cement, thereby preserving its naturally high flow characteristics. However, given the high permeability and under-pressured nature of the Powder River Basin coals, the seams overlying the open-hole interval that have been cased will have encountered significant damage. Attempts to produce through the damaged zone by perforating have achieved limited success 
because the damage goes beyond perforation penetrations, and access to the coal's quality flow characteristics is not achieved.

In the Powder River Basin, the clays and shales interbedded with the coals are notoriously unstable. From an operational standpoint, even small shale or clay intervals in an open-hole completion create difficulties, causing potentially productive wells to be plugged and abandoned. Because of this, large open-hole completions containing multiple coals seams are not a viable option (today's technology) in the Powder River Basin.

Although large interval hydraulic stimulation is used in the San Juan and Uinta basins for CBM development, this approach is also not applicable to the PRB. The stratigraphic section in the PRB has aquifers interbedded with the coal seams. Both the aquifers and the coal seams could be affected by large interval stimulations. The inclusion of stimulated aquifers in the producing section would hinder (or even preclude) efficient dewatering of the coal seams.

\subsection{Testing Multi-Seam Well Completion Technology in the Warrior Basin}

\subsubsection{Background}

Possibly the most rigorous investigation of multi-seam completion technology for coalbed methane was performed at the Rock Creek Field Research Site, and at other research sites in the Warrior Basin. The description of GRI's Rock Creek Project is as follows:

"The Multiple Coal Seam Project is a multi-year, joint venture investigating the combination of drilling, completion, stimulation, and production parameters required for the economic production of methane from shallow, multiple coal seams."

R\&D work at Rock Creek on multiple completions technology was, in general, successful. However, investigations of the application and performance of this technology clearly showed that additional technical issues remain to be solved. 


\subsubsection{Multi-Seam Completion Analysis}

Subsequent to the research work at the Rock Creek Multiple Coal Seam Completion Project, a detailed investigation of underperforming multi-seam completed CBM wells was undertaken in several additional areas of the Warrior Basin by multiple CBM technical service firms.

A series of diagnostic tools were used to identify the performance of and problems with multi-seam completion technology in these wells, including:

- A wireline conveyed downhole camera to identify well-specific problems involving plugging and non-stimulation of coal intervals;

- Production logging involving the use of both 1 inch and 3 inch outside diameter (OD) tools for determining productive zones;

- A zone isolation tool (a multiple-packer assembly) to secure accurate contribution of gas flow from each zone; and

- A series of "tank tests" to provide information required for pressure-transient analysis.

The overall findings from this investigation of multi-seam completion practices in the Warrior Basin were as follows:

- Untreated coal zones/seams. Camera surveys, confirmed by subsequent flow tests, showed that a significant number of well perforations did not have evidence of abrasion or sand from the hydraulic fracture. In the Hendrix \# 3510 test well, 29 percent of the 32 perforation sets in the upper zone were not abraded, and 64 percent of the 22 perforation sets in the lower zone were not abraded, as shown in Figure 4-5. Camera inspection of the Soterra 9-7 \#1 well indicated no evidence of perforation abrasion, and production testing confirmed no fluid flow from two of the thickest coal intervals in the well (Figure 4-6). 


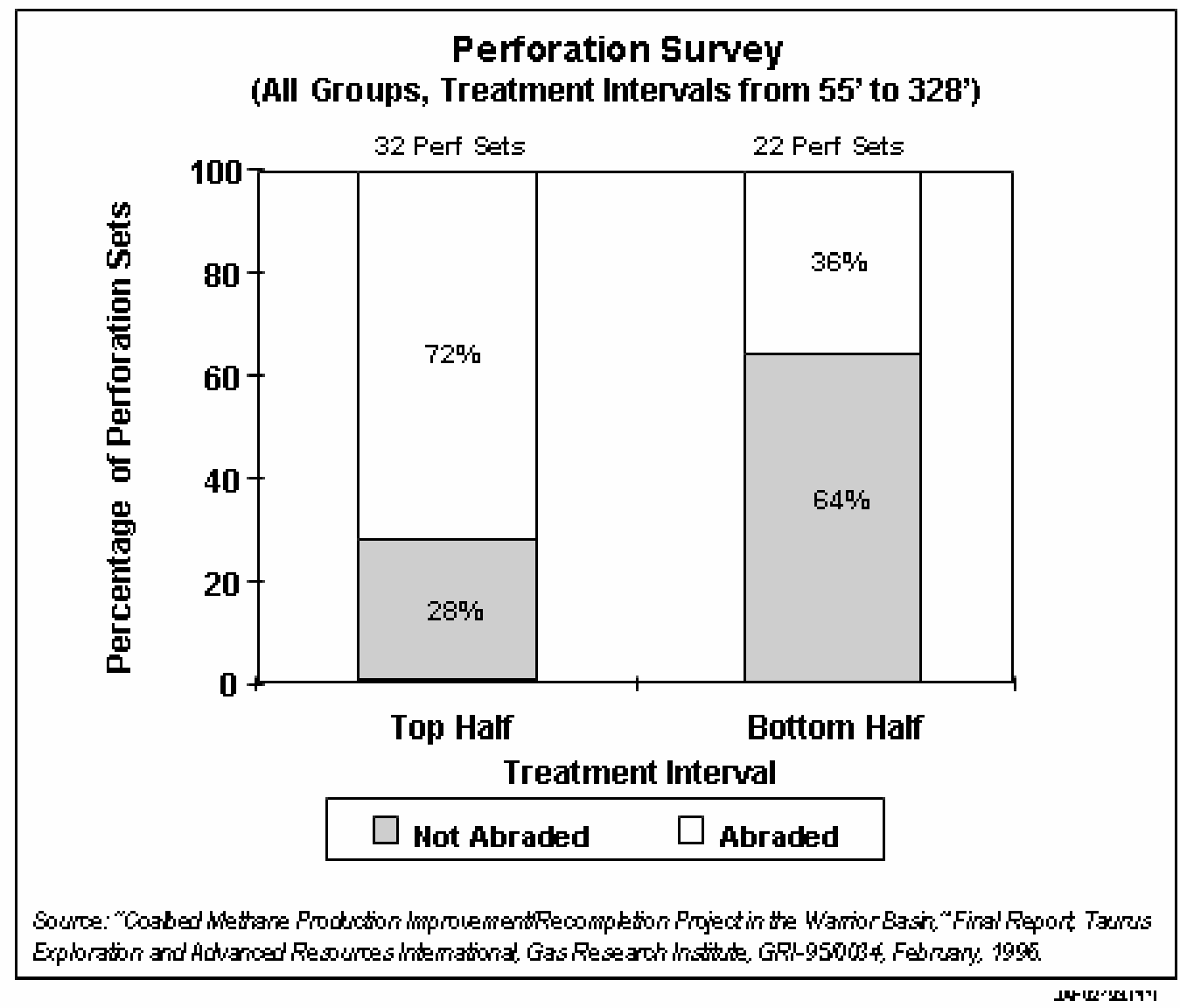

Figure 4-5. Percentage Distribution of Abraded Perforation Sets within Treatment Intervals, Hendrix Study Area Wells. 


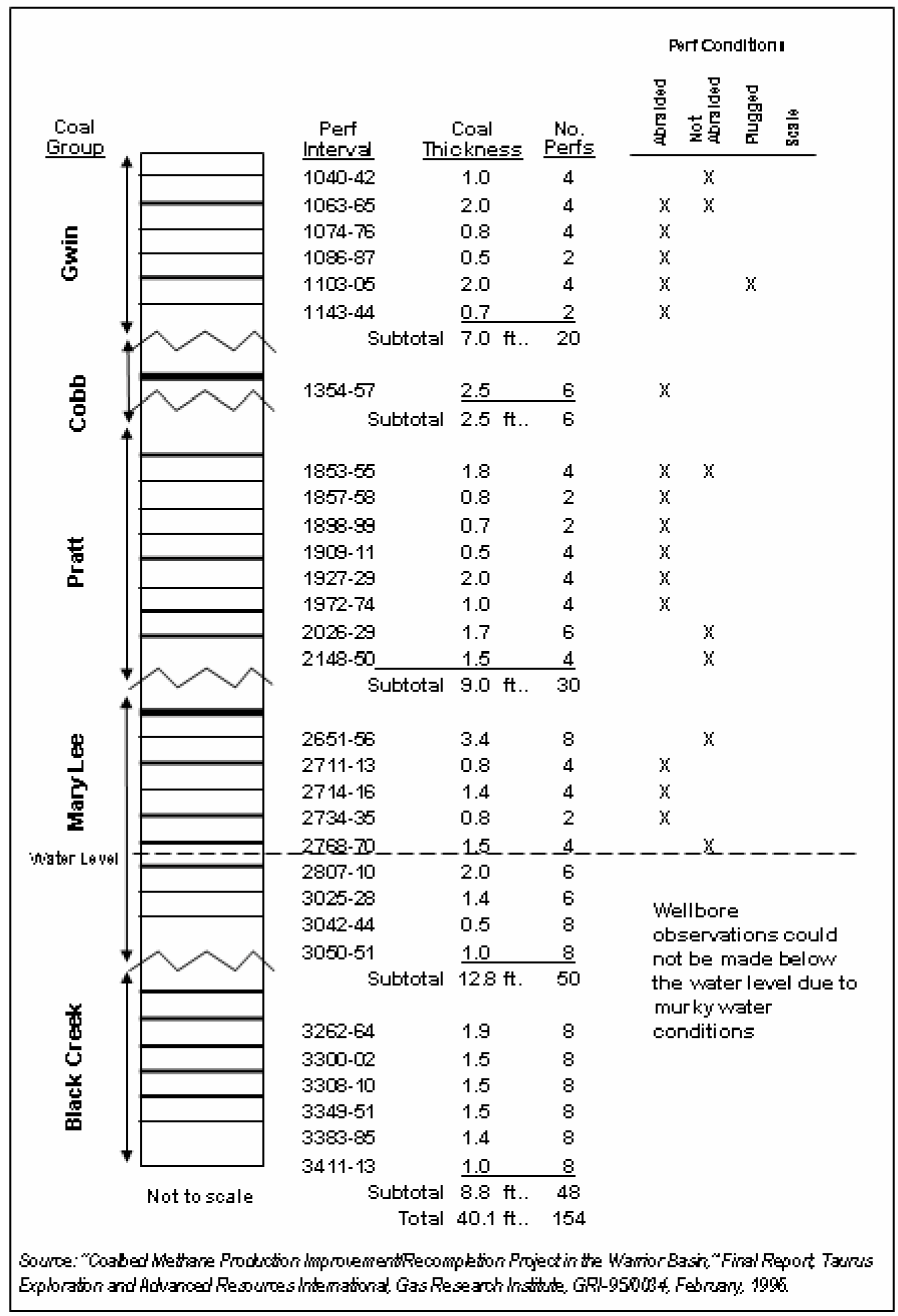

וירונדיה

Figure 4-6. Downhole Camera Observations at the Soterra 9-7 \#1 Well.

- Perforation plugging. Camera surveys showed that perforation plugging (with mineralized scale, coal particles and other unidentified substances) appear to be a common problem. In the Hendrix \# 3510 test well, plugging was found 
present within six of the seven sets of perforations examined in the wellbore by the camera survey.

- Cement damage. The investigation identified considerable volume of cement "lost in high permeability, naturally fractured wells, likely causing significant reservoir damage." In the Soterra 9-7 \#1 well, the evaluation of the cementing operation indicated that the Cobb seam and portions of the Gwin and Pratt coal seams were so damaged during the cementing operation as to preclude gas flow and remediation.

- Horizontal fractures in shallow coals. The analysis of a series of five shallow 1,100 to 1,200 wells (including the Oak Grove \#681 well, shown in Figure 4-7), indicated that a marginally productive top coal seam accepted almost all of the treatment during the initial stimulation, leaving the deeper, main coal zones unstimulated.

This research-based well performance investigation in the Warrior Basin provided important information for improving the application of multi-seam well completion technology in other CBM basins.

The current application of multi-seam technology in the San Juan, Raton and Unita CBM basins, along with its applicability and relevance to the Powder River Basin, are provided in Appendix A. The data and information on the application of multi-seam technology in these other basins were assembled from state files and company records. 


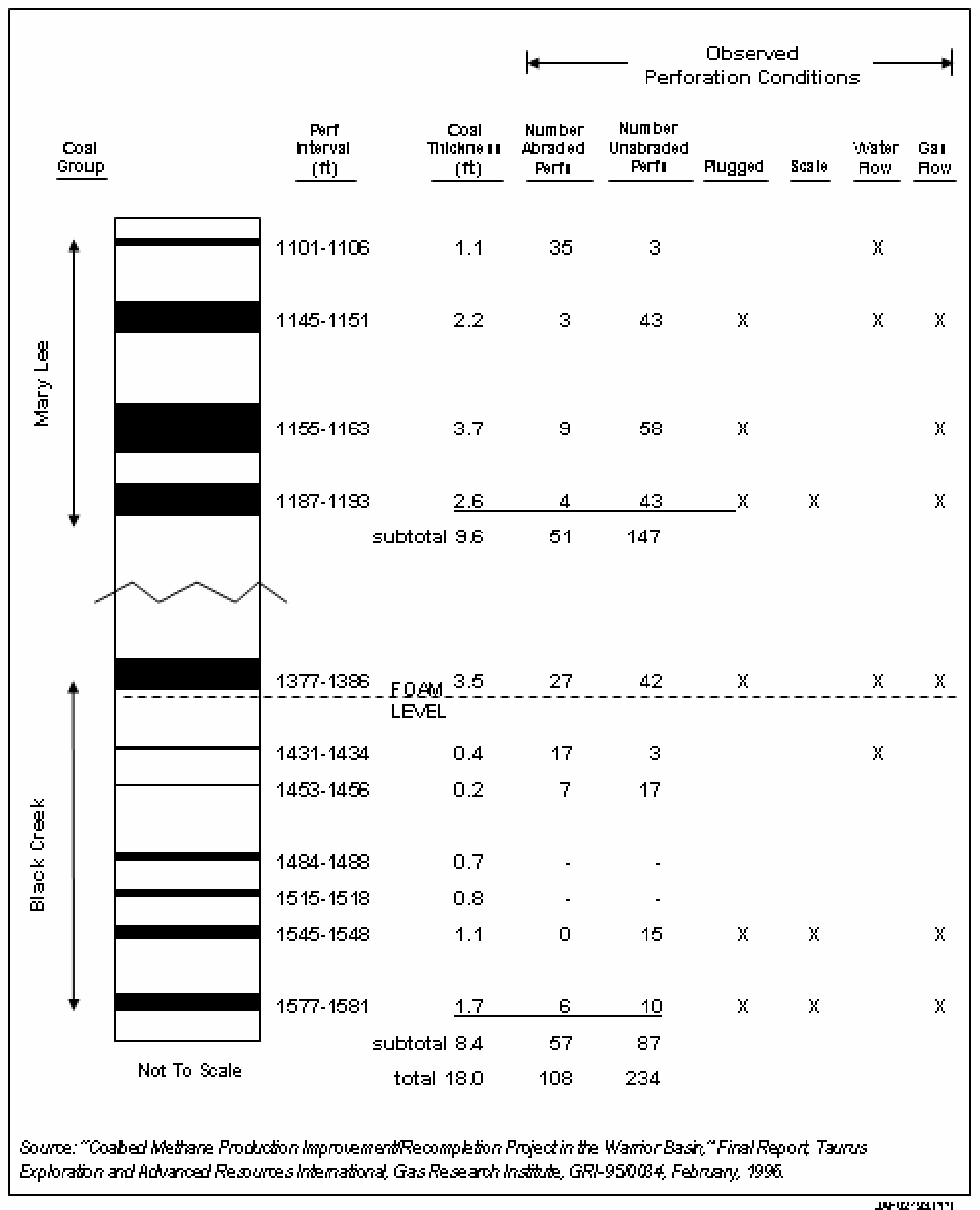

Figure 4-7. Downhole Camera Observations, Oak Grove \#681 Study Well. 


\section{SECTION 5. BENEFITS OF MULTI-SEAM COMPLETION TECHNOLOGY IN THE POWDER RIVER BASIN}

\subsection{Summary}

The potential benefits of adapting and successfully applying multi-seam completion (MSC) technology in the Powder River Basin are numerous. First is the access this technology would provide to the vast CBM resource residing in thinner coal seams. Second is the improved economics that MSC technology would bring to the CBM play. Third is the increased royalty and severance tax revenues that would accrue to Montana, Wyoming, and the federal government. Fourth, and equal in importance, is the potential reduction in environmental impact that would result from producing this vast CBM resource with fewer wells.

\subsection{Increased Natural Gas Resources}

Multi-seam completion technology provides economic and physical access to previously bypassed thin $(<20 \mathrm{ft})$ coal seams. Successful application of this technology would increase the accessible coalbed methane gas in-place to $75 \mathrm{Tcf}$ and raise the technically recoverable CBM resource in this basin to $50 \mathrm{Tcf}^{1}$, as shown in Figure 5-1. Table 5-1 provides details on the coal and coalbed methane in-place as well as the technically recoverable coalbed methane resource in the Powder River Basin, by basin partition.

The application of this technology is particularly relevant to the coalbed methane resource in the Montana portion of the Powder River Basin, an area dominated by thin, marginal coals. With MSC technology, the accessible CBM resource in-place in Montana (in Basin Partitions \#9, \#10 and \#13) is nearly 6 Tcf, with over 5 Tcf being technically recoverable. Figure 5-2 provides an outline map of the thirteen partitions in the Powder River Basin.

1. Produced water (from dewatering operations) volumes are forecast to be commensurate with natural gas production levels 


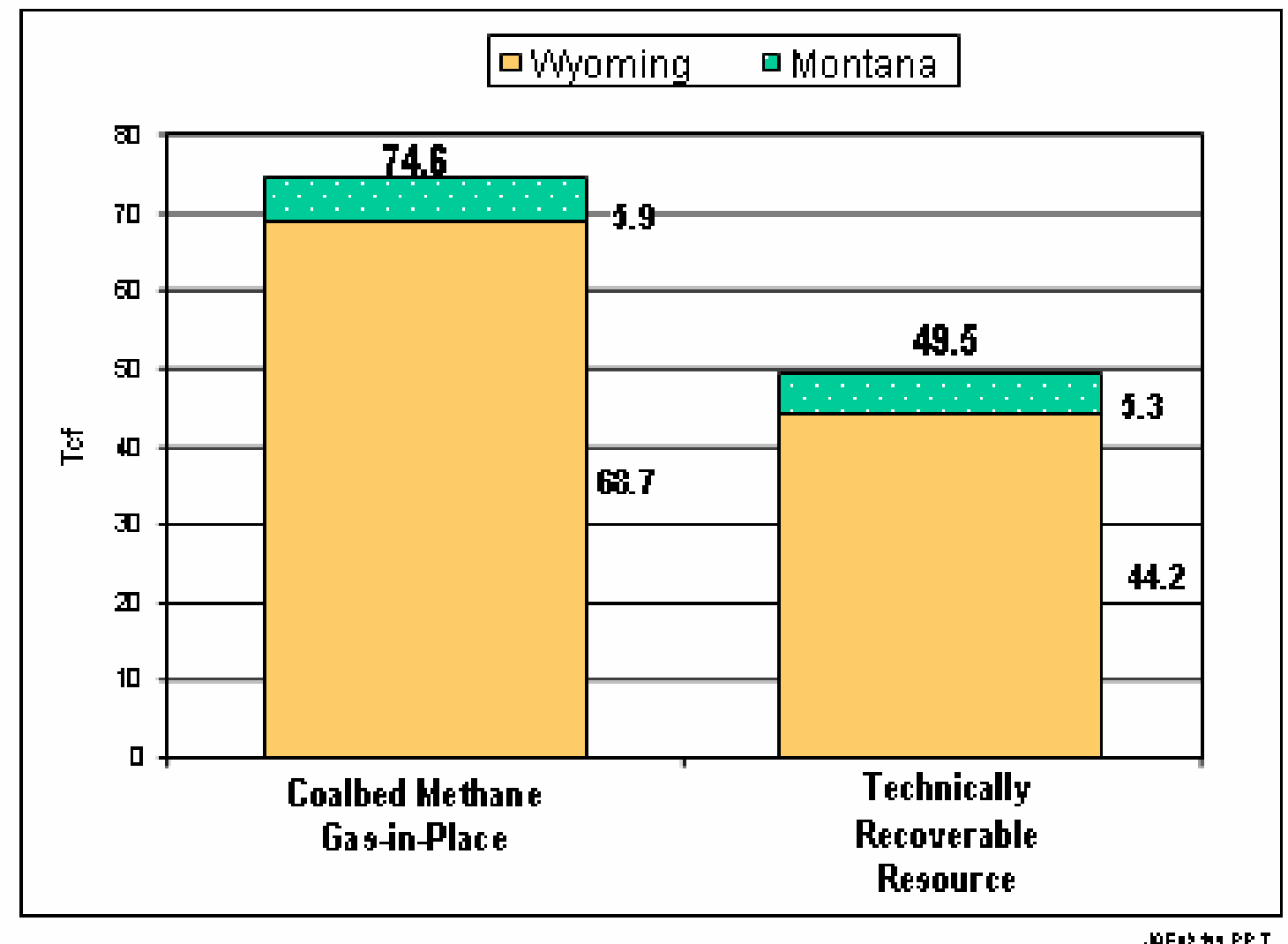

Figure 5-1. Gas-in-Place and Technic ally Recoverable CBH Re source, Powder River Basin. 
Table 5-1. Coal and Coalbed Methane Resources of the Powder River Basin, by Basin Partition.

\begin{tabular}{|c|c|c|c|c|}
\hline & & Coal Resource & $\begin{array}{l}\text { Coalbed Methane } \\
\text { Gas-in-Place }\end{array}$ & $\begin{array}{c}\text { Technically Recoverable } \\
\text { Resources }\end{array}$ \\
\hline & Basin Partitions & (Btons) & (Bcf) & (Bcf) \\
\hline \multirow{11}{*}{ है } & 1 & 20 & 1,630 & 1,440 \\
\hline & 2 & 51 & 2,710 & 2,120 \\
\hline & 3 & 84 & 6,460 & 3,580 \\
\hline & 4 & 83 & 4,360 & 3,470 \\
\hline & 5 & 311 & 25,860 & 15,650 \\
\hline & 6 & 99 & 9,440 & 5,340 \\
\hline & 7 & 69 & 6,340 & 3,570 \\
\hline & 8 & 177 & 9,120 & 6,870 \\
\hline & 11 & 43 & 2,480 & 2,050 \\
\hline & 12 & 4 & 330 & 150 \\
\hline & Sub-Total & 941 & 68,730 & 44,240 \\
\hline \multirow{4}{*}{ 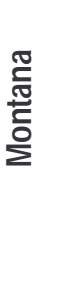 } & 9 & 53 & 2,680 & 2,400 \\
\hline & 10 & 39 & 1,490 & 1,330 \\
\hline & 13 & 48 & 1,720 & 1,540 \\
\hline & Sub-Total & 140 & 5,890 & 5,270 \\
\hline \multicolumn{2}{|r|}{ Totals } & 1081 & 74,620 & 49,510 \\
\hline
\end{tabular}

Source: DOE/Advanced Resources International PRB CBM data base, 2003. 


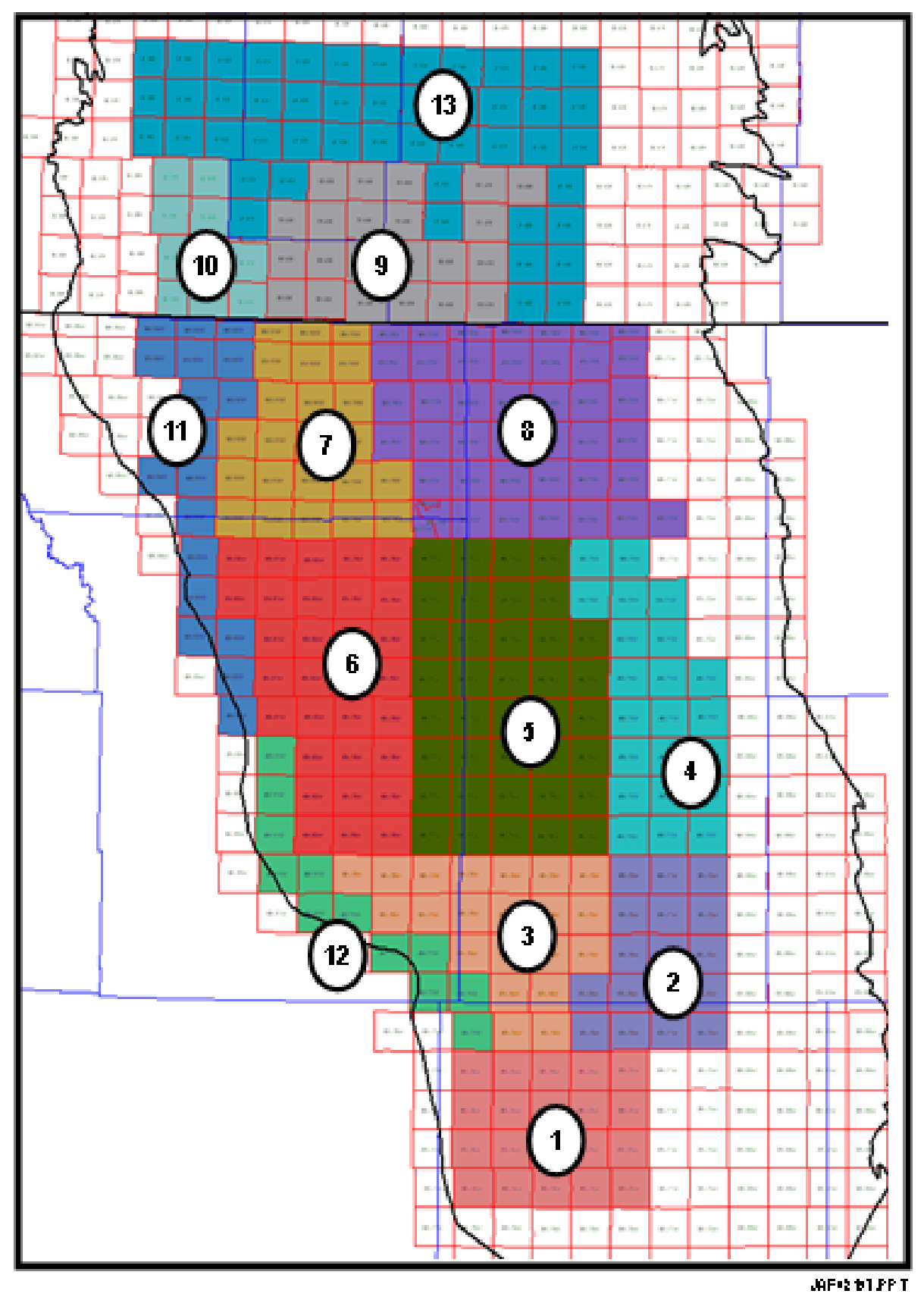

Figure 5-2. Powder River Basin CBM Partitions (MSC study). 


\subsection{Larger Economically Recoverable Resource}

Multi-seam completion technology can also help to increase the size of the economically recoverable coalbed methane resource in the Powder River Basin. Using a \$3.50/Mcf Henry Hub price for natural gas and a basis differential declining from $\$ 1.80 /$ Mcf toward historical norms of $\$ 0.80 / \mathrm{Mcf}$, labeled as Scenario \#2 in this study, more than $38 \mathrm{Tcf}$ of coalbed methane is economically recoverable from the Powder River Basin. This includes both previously bypassed thin coal seams, as well as marginally thick coal seams that are uneconomic to develop with currently used single-seam technology.

Table 5-2 presents the economically recoverable CBM resource for Wyoming and Montana, as well as the number of CBM wells expected to be drilled, by mineral ownership based on data provided in Wyoming's Draft EIS for the Powder River Basin.

Table 5-2. Economically Recoverable CBM by Mineral Ownership

\begin{tabular}{|c|c|c|c|c|}
\hline \multirow[b]{3}{*}{ Mineral Ownership* } & \multicolumn{3}{|c|}{ Economically Recoverable CBM } & \multirow{3}{*}{$\begin{array}{c}\text { Number of CBM } \\
\text { Wells Drilled }\end{array}$} \\
\hline & \multicolumn{3}{|c|}{ (Bcf) } & \\
\hline & WY & MT & Total & \\
\hline Federal & 22,610 & 820 & 23,430 & 40,580 \\
\hline State & 2,590 & 100 & 2,690 & 4,660 \\
\hline Private & 11,860 & 430 & 12,290 & 21,290 \\
\hline Total & 37,060 & 1,350 & 38,410 & 66.530 \\
\hline
\end{tabular}

Assumes Scenario \#2 economics of \$3.50/Mcf for natural gas at Henry Hub and a declining basis differential toward historic norms.

* Based on simplified methodology 


\subsection{Increased State and Federal Revenues}

The larger economically recoverable CBM resource, due to multi-seam technology, will provide significantly higher state, federal and private revenues from royalty payments, ad valorem taxes, and severance taxes. In addition, developing this natural gas resource will inject billions of dollars of additional capital expenditures into the economies of Wyoming and Montana, increasing jobs and public infrastructure.

Royalty payments would provide $\$ 10,450$ million of revenue, with $\$ 5,540$ million from federally owned lands, $\$ 850$ million from state-owned lands, and $\$ 4,060$ million from CBM leases on private lands. The states of Montana and Wyoming would receive half of the royalty income from leases on federal lands, raising the royalty income to the states to $\$ 3,620$ million from CBM development in the Powder River Basin. Ad valorem and severance taxes would add another $\$ 7,400$ million of state and local revenues.

Finally, CBM development would provide additional stimulus to state and local economies. Over the life of the CBM play, an estimated $\$ 10.8$ billion in capital expenditures (based on ARl's cost model) would be injected in the basin, providing jobs, infrastructure, and other commerce. Table 5-3 summarizes the revenue benefits that would result from successful development and application of MSC technology in the Powder River Basin for Wyoming and Montana.

Table 5-3. State and Federal Revenues From CBM Development (PRB).

\begin{tabular}{|c|c|c|c|c|c|r|}
\hline \multirow{2}{*}{ Mineral Ownership } & \multicolumn{3}{|c|}{ Royalty Revenues (Millions) } & \multicolumn{3}{c|}{$\begin{array}{c}\text { Ad Valorem and Severance } \\
\text { Tax Revenues (Millions) }\end{array}$} \\
\cline { 2 - 7 } & $\mathbf{W Y}$ & $\mathbf{M T}$ & Total & $\mathbf{W Y}$ & $\mathbf{M T}$ & Total \\
\hline Federal & $\$ 5,342$ & $\$ 194$ & $\$ 5,536$ & $\$ 4,390$ & $\$ 123$ & $\$ 4,513$ \\
\hline State & $\$ 819$ & $\$ 30$ & $\$ 849$ & $\$ 504$ & $\$ 15$ & $\$ 519$ \\
\hline Private & $\$ 3,920$ & $\$ 146$ & $\$ 4,066$ & $\$ 2,303$ & $\$ 65$ & $\$ 2,368$ \\
\hline Total & $\$ 10,081$ & $\$ 370$ & $\$ 10,451$ & $\$ 7,197$ & $\$ 203$ & $\$ \mathbf{7 , 4 0 0}$ \\
\hline
\end{tabular}




\subsection{Economic Sensitivity}

The potential benefits of multi-seam well completion technology was examined for two economic scenarios, each assuming a $\$ 3.50$ per Mcf natural gas price at the Henry Hub. In Economic Scenario \#1, the basis differential is assumed to remain high, at $\$ 1.80$ per Mcf. This scenario assumes that growth in CBM and other natural gas production in the region maintains an excess of gas supply over pipeline takeaway capacity. In Economic Scenario \#2, the basis differential is assumed to decline from $\$ 1.80$ per Mcf down to $\$ 0.80$ per Mcf over a period of three years. This scenario assumes that the high basis differential common to the PRB during the past several years returns to historical norms as new natural gas pipelines are completed, enabling the produced CBM to reach high value markets.

- Under Scenario \#1, the economically recoverable CBM resource ${ }^{1}$ is $24.3 \mathrm{Tcf}$, less than half of the $49.5 \mathrm{Tcf}$ of technically recoverable resource.

- Under Scenario \#2, the economically recoverable CBM resource ${ }^{1}$ is $38.4 \mathrm{Tcf}$, over three-quarters of the technically recoverable CBM resource.

The first insight from this economic sensitivity analysis is that reducing the current high basis differential would enable over 14 Tcf of additional coalbed methane to become economic to develop.

A second important insight is that further economic development of the Montana coalbed methane resource will hinge greatly on reducing the current high basis differential, thus improving the netback wellhead gas price for this portion of the basin.

Figure 5-3 and Table 5-4 show the economically recoverable resource for the constant basis differential (Scenario \#1) situation, and the declining basis differential (Scenario \#2) situation.

1. Produced water (from dewatering operations) volumes are forecast to be commensurate with natural gas production levels 
Table 5-4. Economically Recoverable CBM Resources for Scenarios \#1 and \#2.

\begin{tabular}{|c|c|c|}
\hline & Scenario \#1 & Scenario \#2 \\
\hline & \multicolumn{2}{|c|}{ (Tcf) } \\
\hline Wyoming & 24.3 & 37.1 \\
\hline Montana & 0.0 & 1.3 \\
\hline Total & 24.3 & 38.4 \\
\hline
\end{tabular}

\subsection{Reduced Environmental Impacts}

Multi-seam well completion technology, would significantly reduce the required number of CBM wells by enabling a single well to jointly produce several coal seams, and thus reduce the impact of CBM drilling in the Powder River Basin. Assuming 16.9 Tcf of CBM is economically recoverable with the single-seam well completion technology practiced today (as set forth in Figure 5-4 for Scenario \#2), recovering this resource will require the drilling of 40,320 single-seam CBM wells. With MSC technology, 11,000 fewer wells will be needed to recover this same volume of CBM resource, a reduction of 27 percent. Table 5-5 shows the reduction in the number of wells drilled to recover comparable CBM resources by using MSC technology instead of single-seam technology. 


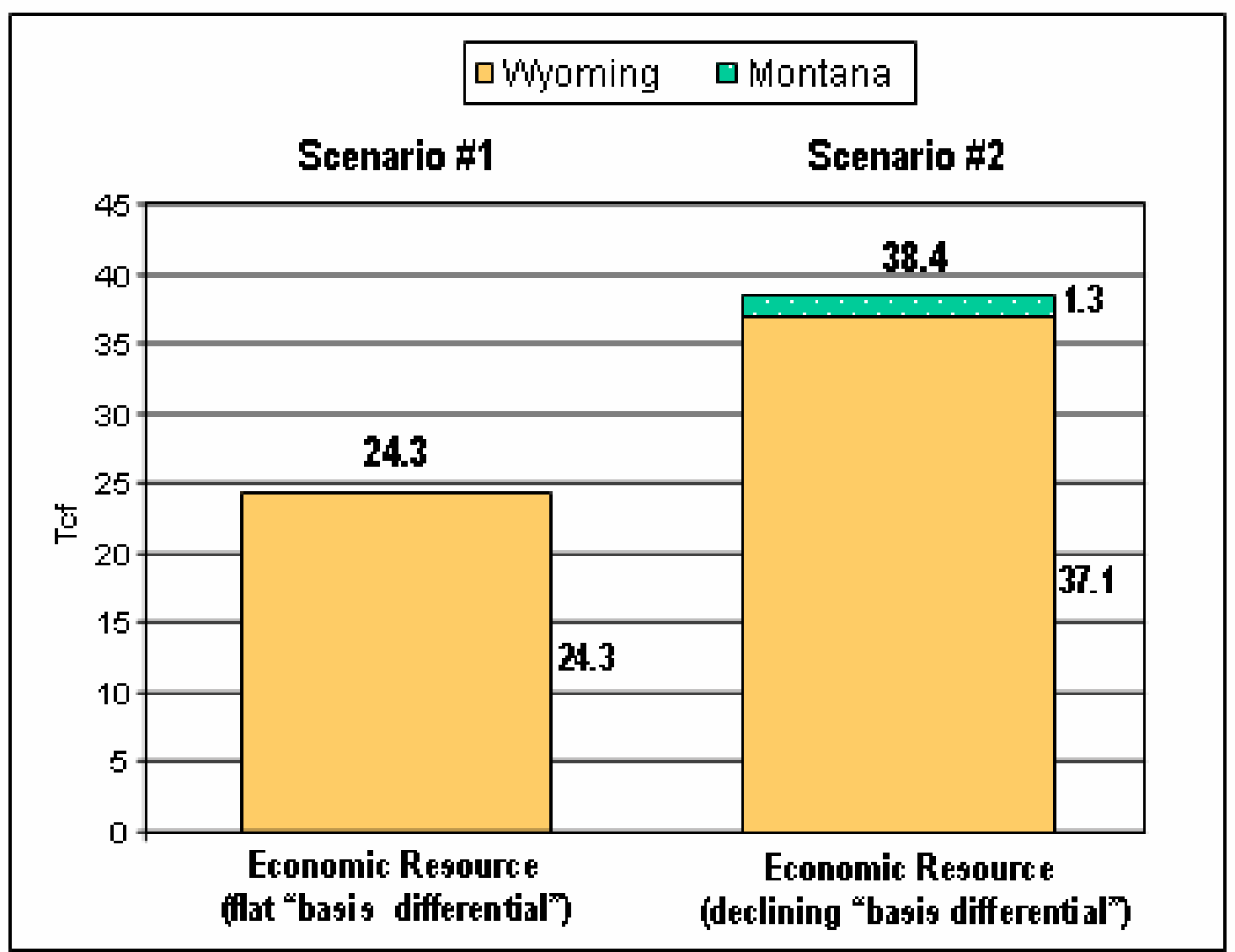

NAFI t $P F T$

Figure 5-3. Economic ally Recoverable CBH Resources;

Two Economic Scenarios, Powder River Basin. 


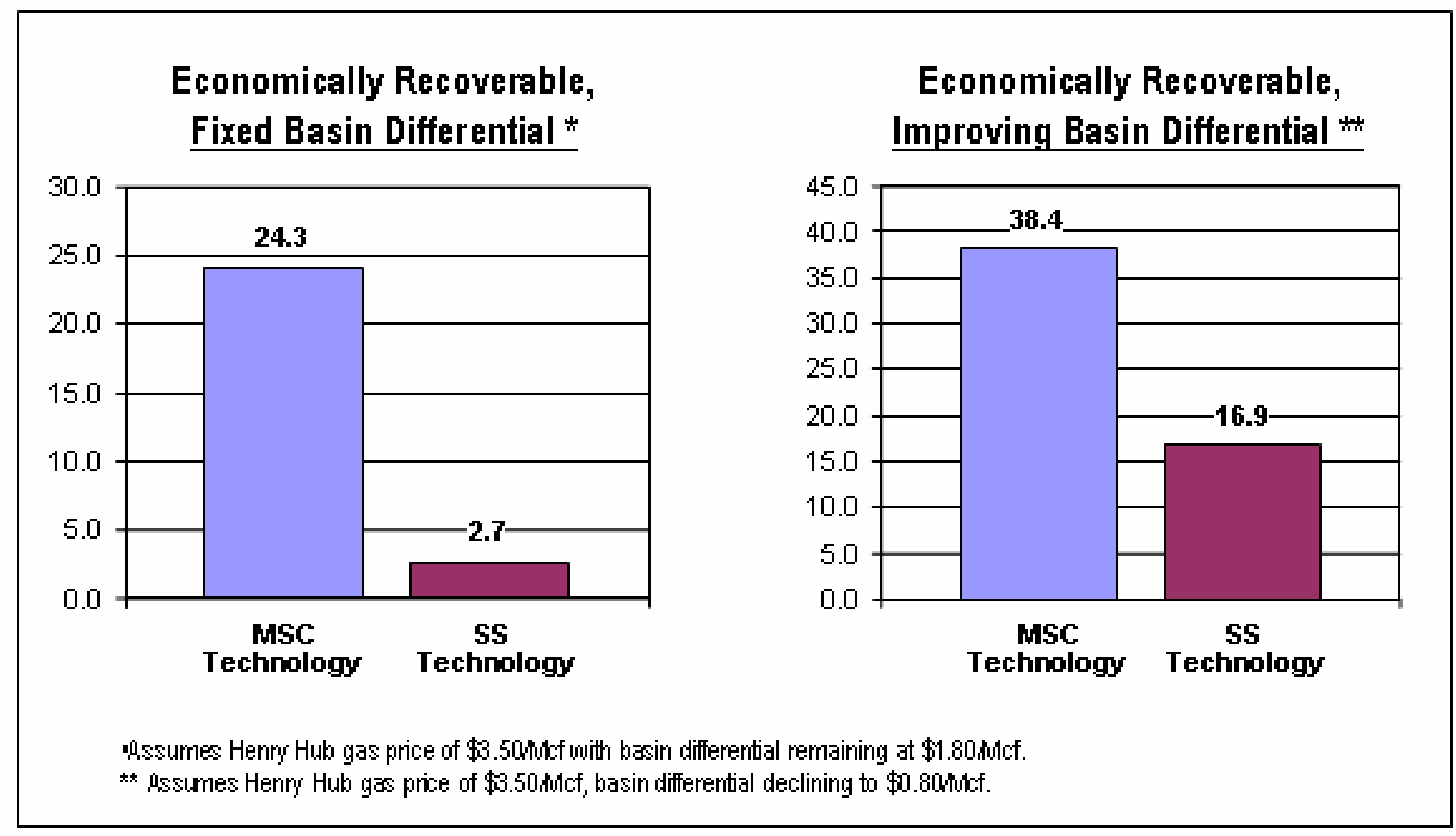

JAFI W $P F T$

Figure 54. Impact of HSC Technology on Economic ally Recoverable CBH Resources from the Powder River Basin, Two Economic Scenarios. 
Table 5-5. Number of Wells Required to Produce CBM Resources in the PRB, Two Alternative Well Completion Technologies.

\begin{tabular}{|c|c|c|c|c|c|}
\hline & Economically & & & \multicolumn{2}{|c|}{$\begin{array}{c}\text { Difference Due to } \\
\text { MSC Technology }\end{array}$} \\
\cline { 5 - 6 } $\begin{array}{c}\text { Well Completion } \\
\text { Technology }\end{array}$ & $\begin{array}{c}\text { Recoverable Resource } \\
\text { Base (Tcf) }\end{array}$ & $\begin{array}{c}\text { Reserves/ Well } \\
\text { (MMcf) }\end{array}$ & $\begin{array}{c}\text { No. of Wells } \\
\text { Required }\end{array}$ & $\begin{array}{c}\text { Total } \\
\text { Wells }\end{array}$ & $\%$ \\
\hline Single-Seam Wells & 16.9 & 419 & 40,320 & - & - \\
\hline Multi-Seam Wells & 16.9 & 577 & 29,260 & $(11,060)$ & $(27 \%)$ \\
\hline
\end{tabular}

* calc. based on single-seam economically recoverable volume of gas

\subsection{Benefits of MSC Technology}

There are many valid reasons for developing and applying MSC technology appropriate to the coals of the Powder River Basin. The most compelling reason is that it would significantly increase the economically recoverable coalbed methane resource in this basin. (And, as discussed above in 5.5 Reduced Environmental Impacts, it would accomplish this with significantly fewer wells.) Using a $\$ 3.50$ per Mcf natural gas price at the Henry Hub, the results are as follows:

- Under Economic Scenario \#1, MSC technology would provide 24.3 Tcf of economically recoverable coalbed methane resource. With continued use of single-seam technology, only 2.7 Tcf would be economically recoverable, a difference of 21.6 Tcf.

- Under Economic Scenario \#2, MSC technology would provide 38.4 Tcf of economically recoverable coalbed methane resource. With continued use of single seam technology, only 16.9 Tcf would be economically recoverable, a difference of 21.4 Tcf.

Figure 5-4 illustrates the impact of that MSC technology would have on economically recoverable CBM resources from the Powder River Basin. Under the two economic scenarios, Tables 5-6 and 5-7 provide additional state level data on the impacts of MSC technology. 
Table 5-6. Distribution of Economic CBM Resources Under Scenario \#1.

\begin{tabular}{|c|c|c|c|}
\hline & SSC Technology & MSC Technology & Difference \\
\hline & (Tcf) & (Tcf) & (Tcf) \\
\hline Wyoming & 2.7 & 24.3 & 21.6 \\
\hline Montana & 0.0 & 0.0 & - \\
\hline Total & 2.7 & 24.3 & 21.6 \\
\hline
\end{tabular}

Table 5-7. Distribution of Economic СBM Resources Under Scenario \#2.

\begin{tabular}{|c|c|c|c|}
\hline & SSC Technology & MSC Technology & Difference \\
\hline & (Tcf) & (Tcf) & (Tcf) \\
\hline Wyoming & 16.9 & 37.1 & 20.2 \\
\hline Montana & 0 & 1.3 & 1.3 \\
\hline Total & 16.9 & $\mathbf{3 8 . 4}$ & $\mathbf{2 1 . 5}$ \\
\hline
\end{tabular}

\subsection{Detailed Benefits of Using MSC Technology}

Successful MSC technology would beneficially impact CBM development in the Powder River Basin in many ways, as illustrated by the following examples. These four examples cover many of the geologic settings encountered in the PRB, including the central portion of the basin where thin seams coexist with major thick coals, as well as the northern and western basin flanks where much of the coal is deposited primarily in thin seams. 


\subsubsection{Example \#1}

Currently uneconomic, marginally thick coals are completed along with a series of thin coals to make an economic well.

Under current practices, a single seam CBM well targeting the 25-foot Canyon coal seam in T54N R80W would recover $0.21 \mathrm{Bcf}$ of gas and with this low gas recovery, the well is sub-economic. With MSC technology, the Canyon coal seam in this township can be completed with three additional thin seams (16 ft., $19 \mathrm{ft}$., and 15 $\mathrm{ft}$.) that would have been bypassed under current practices. The result is an economic CBM well that would recover 0.57 Bcf. In addition, the packaging of four coal seams in one well significantly lowers finding and development (F\&D) costs in this township from an uneconomic $\$ 0.67 /$ Mcf to an economic $\$ 0.27 /$ Mcf as summarized for Example \#1 in Table 5-8 below.

Table 5-8. Multi Seam Example \#1 - Marginally Economic Thick Coal Seam Is Completed with Thin Seams to Make an Economic CBM Well.

\begin{tabular}{|c|c|c|}
\hline & Current Single-Seam Technology & $\begin{array}{c}\text { Proposed Multi-Seam } \\
\text { Technology }\end{array}$ \\
\hline CAPEX/Well & $\$ 139,950$ & $\$ 154,960$ \\
\hline EUR/Well & $208 \mathrm{MMcf}$ & $566 \mathrm{MMcf}$ \\
\hline Water/Well & $193 \mathrm{Mbw}$ & $368 \mathrm{Mbw}$ \\
\hline Water:Gas Ratio & $0.93 \mathrm{Bw} / \mathrm{Mcf}$ & $0.65 \mathrm{Bw} / \mathrm{Mcf}$ \\
\hline F\&D Cost & $\$ 0.67 \mathrm{per}$ Mcf & $\$ 0.27 \mathrm{per} \mathrm{Mcf}$ \\
\hline
\end{tabular}

\subsubsection{Example \#2}

Several thin coal seams bypassed under present practices are completed, along with a currently economic seam to increase reserves per well while adding relatively little to capital costs.

A single seam CBM well targeting the 50 -foot Anderson coal seam in T45N $\mathrm{R} 77 \mathrm{~W}$ would recover $0.53 \mathrm{Bcf}$ of gas and would be economic under present wellhead price conditions. However, several nearby thin seams are not economic. 
With MSC technology, one shallower 19 foot coal seam and two deeper coal seams (19 ft. and $10 \mathrm{ft}$.) can be completed with the economic Anderson seam, increasing well reserves to nearly $1.0 \mathrm{Bcf}$. The additional recovery from the thin seams offset the modest increase in drilling and completion costs, lowering F\&D costs to $\$ 0.17$ per Mcf as summarized in Table 5-9.

Table 5-9. Multi Seam Example \#2 - Thin Seams Are Completed with an Economic Thick Coal Seam to Increase Well Reserves.

\begin{tabular}{|c|c|c|}
\hline & $\begin{array}{c}\text { Current Single-Seam } \\
\text { Technology }\end{array}$ & $\begin{array}{c}\text { Proposed Multi-Seam } \\
\text { Technology }\end{array}$ \\
\hline CAPEX/Well & $\$ 130,470$ & $\$ 167,960$ \\
\hline EUR/Well & $531 \mathrm{MMcf}$ & $967 \mathrm{MMcf}$ \\
\hline Water/Well & $161 \mathrm{Mbw}$ & $449 \mathrm{Mbw}$ \\
\hline Water:Gas Ratio & $0.30 \mathrm{Bw} / \mathrm{Mcf}$ & $0.46 \mathrm{Bw} / \mathrm{Mcf}$ \\
\hline F\&D Cost & $\$ 0.25 \mathrm{per} \mathrm{Mcf}$ & $\$ 0.17 \mathrm{per} \mathrm{Mcf}$ \\
\hline
\end{tabular}

\subsubsection{Example \#3}

Two (or more) economic seams are completed with the same well to reduce capital expenditures while cutting the required number of CBM wells in half (or less).

The Anderson (60 ft.) and the Canyon (60 ft.) coal seams in T49N R73W both provide economic CBM wells even when they are completed separately. A well producing from each of these seams will recover over $0.3 \mathrm{Bcf}$. With MSC technology, the Anderson and Canyon seams are completed in a single well, along with two sub-economic thick seams (both $25 \mathrm{ft}$.), increasing reserve per well, reducing the number of required CBM wells, and reducing total capital expenditures by $\$ 86,500$, as summarized in Table $5-10$. 
Table 5-10. Multi Seam Example \#3-Multiple Economic Coal Seams Are Completed in a Single Well to Reduce Capital Expenditures and Surface Disturbance.

\begin{tabular}{|c|c|c|}
\hline & $\begin{array}{c}\text { Current Single-Seam } \\
\text { Technology }\end{array}$ & $\begin{array}{c}\text { Proposed Multi-Seam } \\
\text { Technology }\end{array}$ \\
\hline CAPEX/Well & $\$ 227,720^{*}$ & $\$ 141,180$ \\
\hline EUR/Well & $667 \mathrm{MMcf}^{\star}$ & $834 \mathrm{MMcf}$ \\
\hline Water/Well & $623 \mathrm{Mbw}$ & $817 \mathrm{Mbw}$ \\
\hline Water:Gas Ratio & $0.93 \mathrm{Bw} / \mathrm{Mcf}$ & $0.98 \mathrm{Bw} / \mathrm{Mcf}$ \\
\hline F\&D Cost & $\$ 0.34 \mathrm{per} \mathrm{Mcf}$ & $\$ 0.17 \mathrm{per} \mathrm{Mcf}$ \\
\hline
\end{tabular}

${ }^{*}$ Two single-seam well costs and reserves are combined for this table.

\subsubsection{Example \#4}

A basin area containing only thin coals is made economic by completing up to four seams in one well. This case is of particular importance in on the western side of the Powder River CBM play and in Montana where thick (>20 ft.) coals are much less common.

Under current practices, coals less than 20 feet thick are generally bypassed. As development using single-seam completion technology progresses, the likelihood that operators will return to an area to complete such seams in individual wells is in doubt. With MSC technology, coalbed gas from these bypassed townships can be economically produced. For example, T51N R81W contains several deep thin coal seams that would be bypassed under current conditions. With MSC technology, four seams (three $18 \mathrm{ft}$. coal seams and one $11 \mathrm{ft}$. seam) are completed in a single well that will recover over 0.68 Bcf, as summarized in Table 5-11. 
Table 5-11. Multi Seam Example \#4 - An Uneconomic Township Is Made Economic Using MSC Technology.

\begin{tabular}{|c|c|c|}
\hline & $\begin{array}{c}\text { Current Single-Seam } \\
\text { Technology }\end{array}$ & $\begin{array}{c}\text { Proposed Multi-Seam } \\
\text { Technology }\end{array}$ \\
\hline CAPEX/Well & $\mathrm{N} / \mathrm{A}$ & $\$ 232,380$ \\
\hline EUR/Well & $\mathrm{N} / \mathrm{A}$ & $681 \mathrm{MMcf}$ \\
\hline Water/Well & $\mathrm{N} / \mathrm{A}$ & $854 \mathrm{Mbw}$ \\
\hline Water:Gas Ratio & $\mathrm{N} / \mathrm{A}$ & $1.25 \mathrm{Bw} / \mathrm{Mcf}$ \\
\hline F\&D Cost & $\mathrm{N} / \mathrm{A}$ & $\$ 0.34 \mathrm{per} \mathrm{Mcf}$ \\
\hline
\end{tabular}




\section{REFERENCES}

1. U.S. DOE. 2002. Powder River Basin Coalbed Methane Development and Produced Water Management Study. DOE/NETL-2003/1184. Springfield, VA: National Technical Information Service.

2. Wyoming Coalbed Methane Production from the Powder River Basin. 2003. Wyoming Oil and Gas Conservation Commission online database. http://wogcc.state.wy.us/

3. Taurus Exploration, Advanced Resources International, and Gas Research Institute. 1994. "Effective Completions for Shallow Coal Seams," Topical Report. GRI-93/0366. Government sponsored? City, State:

Publisher/office where filed.

4. Taurus Exploration, Advanced Resources International, and Gas Research Institute. 1996. "Coalbed Methane Production Improvement/Recompletion Project in the Warrior Basin," Final Report GRI95/0034.. Government sponsored? City, State: Publisher/office where filed.

5. "Rocky Mountain Production." 2003. IHS Energy, PI/Dwights Plus, Volume 13, Issue 2.

6. "Rocky Mountain Well," 2003. IHS Energy, PI/Dwights Plus, Volume 13, Issue 2. 


\section{APPENDIX A}

\section{ASSESSMENT OF MULTI-SEAM WELL COMPLETION PRACTICES: \\ SAN JUAN, RATON, AND UINTA CBM BASINS}

\section{SAN JUAN BASIN}

Coalbed Methane Reservoir Setting. The coals in the San Juan Basin are contained in the Fruitland Formation at depths of 2,500 to 3,500 feet. The coalbearing interval is typically 200 to 300 feet, with maximum coal development occurring at the base of the section. Net coal thickness can reach 80 to 100 feet. The coal package consists of 5 to 10 individual seams with individual coal thickness typically 10 to 20 feet, as shown for the Amoco Production Co. \#2 Short Lyle Gas Unit A well, shown in Figure A-1.

The Fruitland section rarely includes sandstones, and when present, the sandstones are typically tight. Shales are generally stable and do not interfere with completion or production operations.

Well Completion Practices. Two distinct coalbed methane well completion practices are used in the San Juan Basin for coalbed methane: (1) cased-hole well completions with single-stage stimulation; and, (2) open-hole well completions with dynamic cavitation. These two practices and their relevance to the Powder River CBM play are briefly discussed below.

Cased-Hole Completion, Single-Stage Stimulation. Casing is cemented in place over the coal section. Every coal seam in the coal interval is perforated. The entire coal section is hydraulically stimulated using a single-stage stimulation. The stimulation consists typically of 90,000 gallons of a high viscosity gel, and 200,000 pounds of sand.

Figure A-1 provides an example of a typical San Juan Basin cased-hole well completion, showing the coal section and the well completion and stimulation practices used to connect multiple coals to a single well. 
Relevance to the PRB. The San Juan Basin stimulations are designed for maximum vertical growth, to connect as many coal seams to the well bore as possible. There is little risk from communicating with underlying or overlying water bearing formations, as the Fruitland formation rarely includes porous and permeable sandstones.

In contrast to the San Juan Basin, porous and permeable sandstones are typically encountered in coal sections of the Powder River Basin. A stimulation design for significant vertical growth would unavoidably communicate with aquifers in the stimulated interval and would delay or preclude dewatering of the coal seams. The multi-seam stimulation method used in the San Juan Basin is not applicable to the PRB.

Open-Hole Completion, Dynamic Cavitation. Casing is set and cemented inplace at the top of the coal interval. The coal interval is drilled out and left open.

The well is stimulated using the dynamic cavitation process where air and water are injected into the well under high pressure. The pressure is rapidly released, causing the open-hole section to surge large volumes of gas, water and coal. The process is repeated until maximum flow rates are achieved.

Figure A-2 provides an example of a typical San Juan Basin open-hole well completion, showing the coal section and the completion practice used to connect the multiple coals in this well.

Relevance to the PRB. Although open-hole cavitation has been attempted in several coal basins in the U.S., it has only been successful in the San Juan Basin fairway. A unique set of favorable reservoir properties is required to achieve successful cavitation.

The reservoir properties necessary for cavitation are not present in the PRB. The shales and clays associated with coals in the PRB are unstable and cannot be included in an open-hole seam, precluding the application of this multi-seam completion approach in the PRB. 


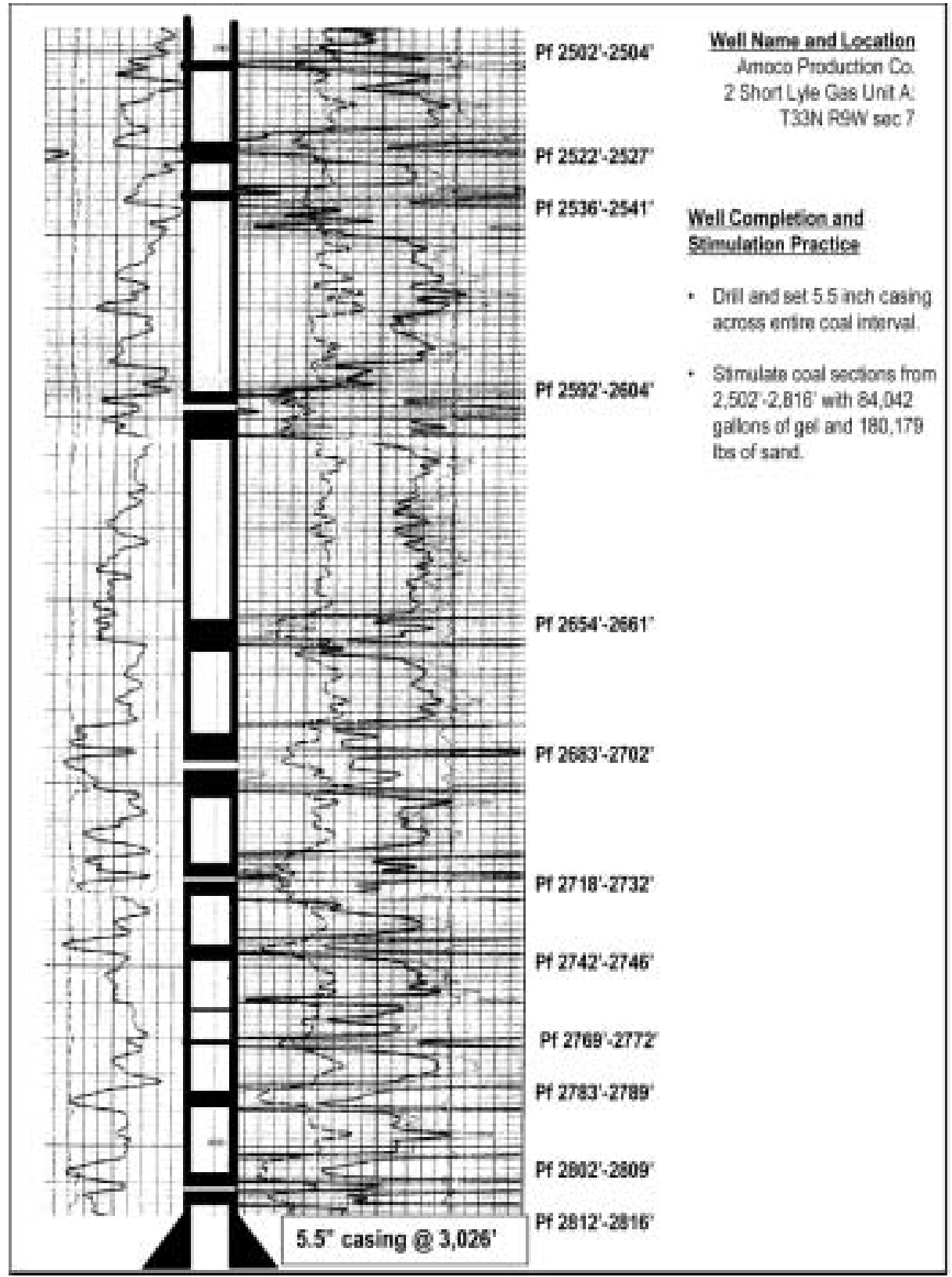

Figure A-1 Cased Hole Completion, Single-Stage Stimulation, San Juan Basin CBM Well. 


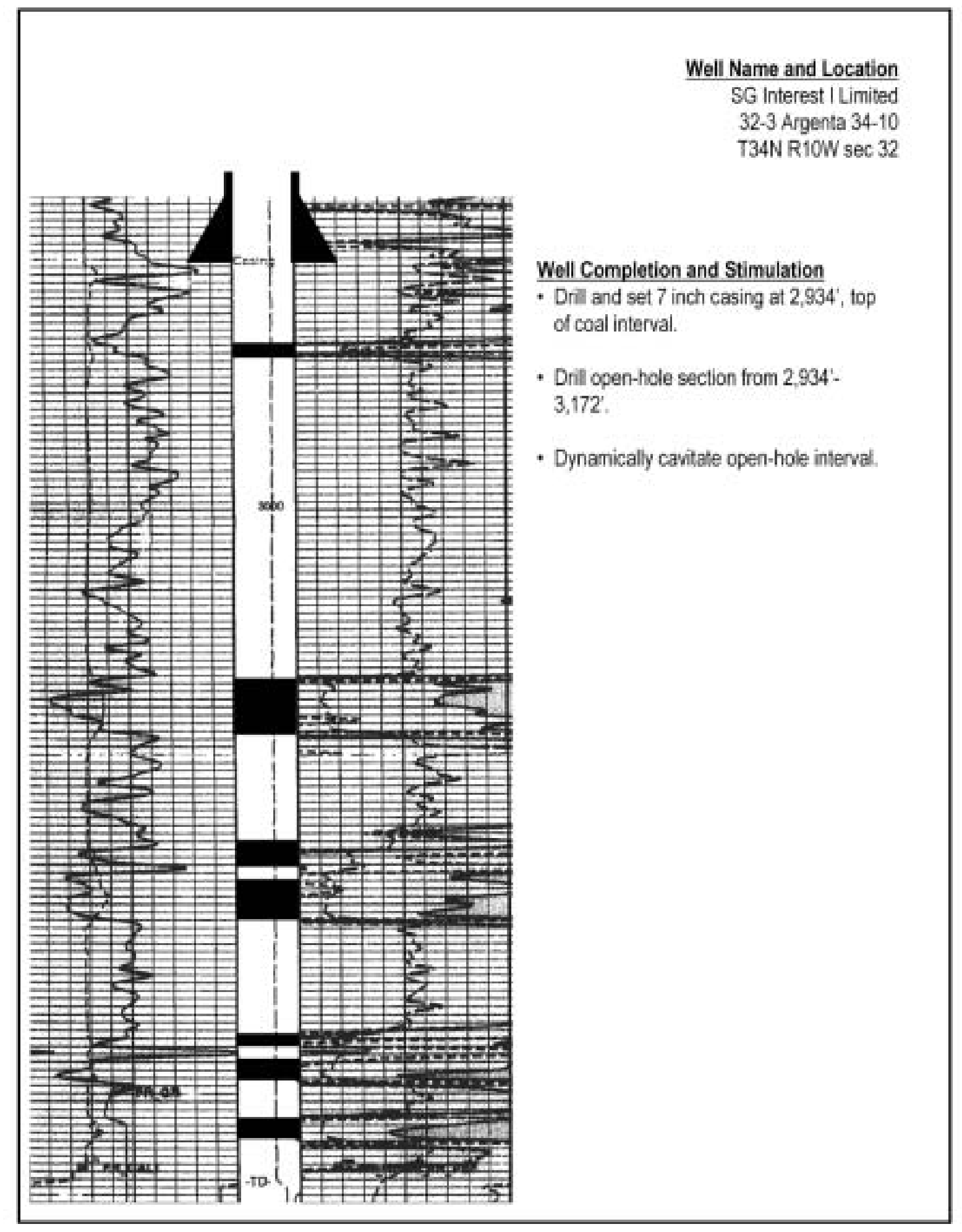

Figure A-2. Open-Hole Completion, Dynamic Cavitation, San Juan Basin CBM Well. 


\section{RATON BASIN}

Coalbed Methane Reservoir Setting. Coal development in the Raton and underlying Vermejo formations is at drilling depths of 1,500 to 2,500 feet. Coal seams in the Raton Formation are typically thin, with individual seam thickness of 2 to 4 feet. Coals as thick as 10 feet are not uncommon, however they tend to be lenticular in nature. Average net coal thickness varies between 20 to 40 feet, with an occasional coal package of over 100 feet. The coal development in the Vermejo Formation is similar to the Raton Formation coal seams.

Figure A-3 provides a well log and completion summary for the Evergreen Operating Corp. \#41-16 Crossbow well in the Raton Basin.

Well Completion Practices. The primary CBM well completion practice in the Raton Basin is a cased-hole well with multiple, relatively small hydraulic fractures. This well completion practice and its relevance to the Powder River CBM play is discussed below.

Cased-Hole Completion, Multiple Stage Stimulation. The wells are drilled underbalanced to reduce formation damage. A 5.5 inch casing string is cemented in place to total well depth. Each coal seam is selectively perforated.

Single coal seams and small intervals containing multiple coal seams are hydraulically stimulated. A single well will have between three and six stimulation stages, depending on the extent of coal development.

The stimulation begins with a small acid break down. This is followed with a larger nitrogen foam breakdown and sand. Cross-linked gel and sand is used in the last stimulation stage. The typical final stimulation stage consists of 200 to 400 barrels of gel and 20,000 to 40,000 pounds of sand.

Figure A-3 provides an example of a typical Raton Basin cased-hole completion, showing the coal section and the well completion and stimulation practices used to connect multiple coals to a single well. 


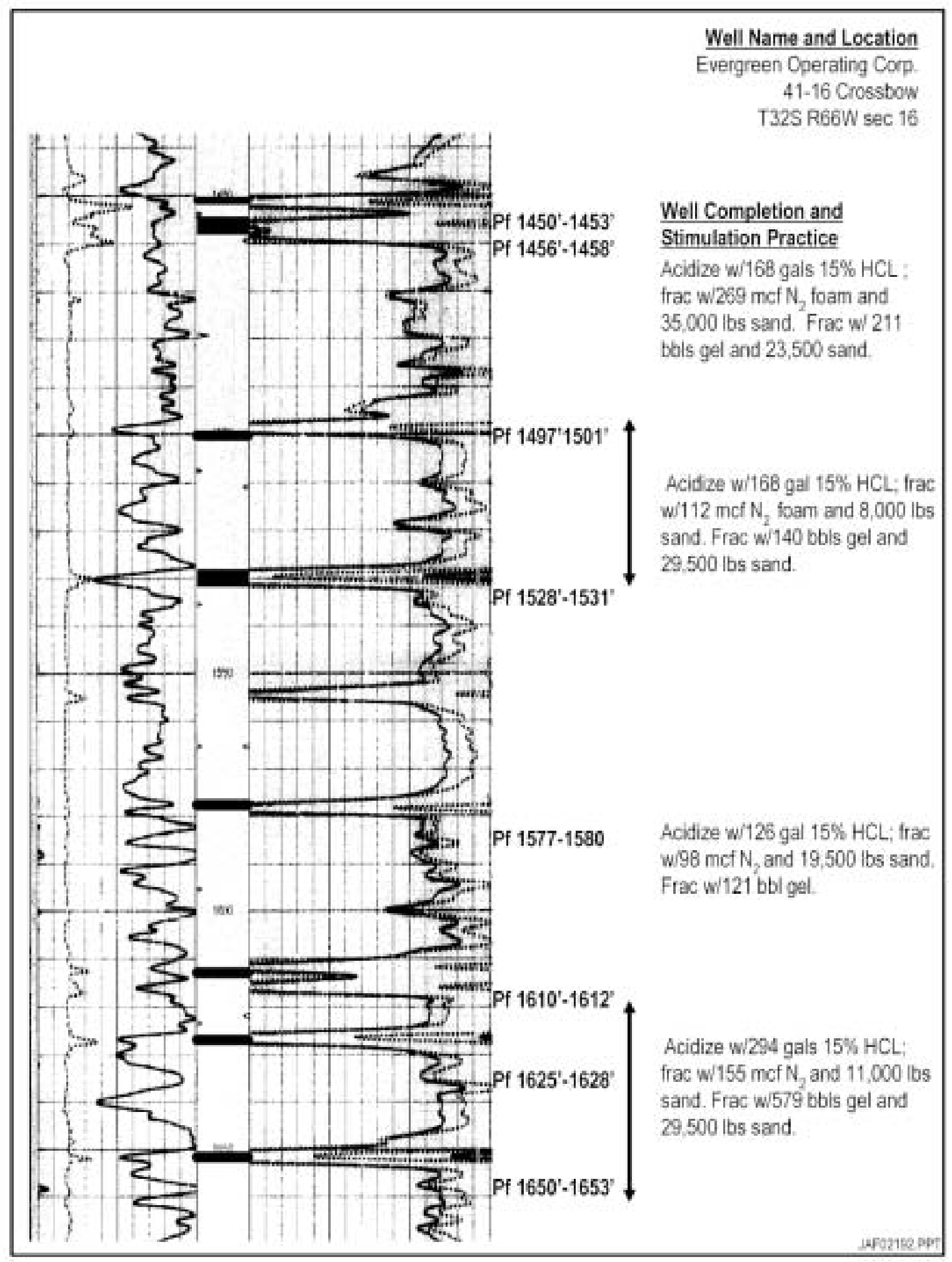

Figure A-3. Cased Hole Completion, Multiple-Stage, Small Interval Stimulation, Raton Basin CBM Well. 
Relevance to the PRB. The emphasis in the Raton Basin is on low cost, multiple seam stimulations. This approach may provide insight for an appropriate well completion and stimulation technology for the Powder River Basin.

A major question is whether the stimulations designed for thin, higher rank coal seams would be applicable to the thicker, low rank coals in the PRB.

In addition, the stimulation fluids used in the Raton Basin might not be appropriate for use in the Powder River Basin. The use of certain additives could possibly be restricted or prohibited in coal seams that are aquifers or in close proximity to sand aquifers.

In summary, it is very probable that significant modifications would be required to transfer Raton Basin well completion and stimulation practices to the Powder River Basin. 


\section{UINTA BASIN}

Coalbed Methane Reservoir Setting. Depth of the Ferron coal varies between 1,200 to 3,400 feet with 2,400 feet being average for current CBM development wells. The Ferron coal sequence typically has three to six coals over a 150 to 200 foot interval. Single coal seam thickness is rarely greater than 10 feet. Net coal thickness can vary between 5 to 35 feet with 24 feet being an average net coal thickness.

Figure A-4 provides a well log and completion summary for the Phillips Petroleum Company \# 7-741 USA well in the Uinta Basin.

Well Completion Practices. The primary CBM well completion practice in the Uinta Basin is a cased-hole well with one or two large vertical interval stimulations.

Cased-Hole Completion, Large Vertical Interval Stimulations. The CBM wells are drilled with air to total depth, with a 5.5 inch casing string cemented in place across the coal interval. Each coal seam is individually perforated.

The wells are hydraulically stimulated using a high viscosity, cross-linked gel. A single well will typically have one or two such treatments across a relatively large formation interval. Hydraulic fracture volumes are typically 50,000 gallons of gel and 50,000 to 90,000 pounds of sand per treatment.

Figure A-4 provides an example of a typical Uinta Basin cased-hole completion, showing the coal section, and the well completion and stimulation practices used to connect multiple coals to a single well.

Relevance to the PRB. The large interval stimulations used in the Uinta Basin are designed for vertical growth, to effectively connect the entire coal section to the well bore. Although, the Ferron coal sequence sometimes includes thin interbedded sandstones, the sand reservoirs are not thought to contribute significantly to water production. 


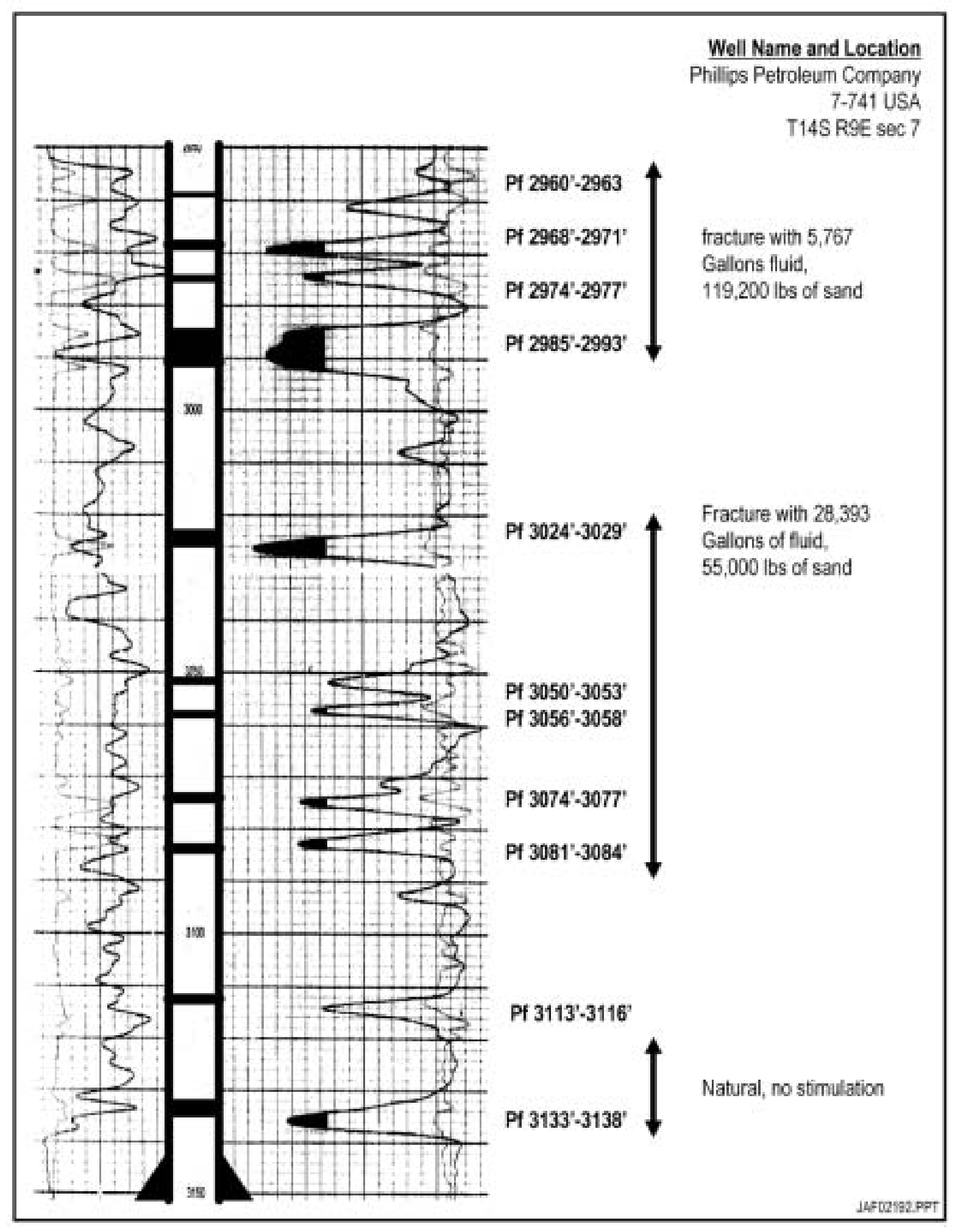

Figure A-4. Cased Hole Completion, Multiple-Stage Large Interval Stimulation, Uinta Basin CBM Well. 
Water-bearing sand aquifers are commonly interbedded with target zones within the PRB coal intervals. The use of a stimulation that is designed for vertical growth would unavoidably connect these aquifers and coal seams. The inclusion of stimulated aquifers would result in excessive water production, hampering or precluding dewatering of the coal seams.

The Uinta Basin multiple-seam well completion and stimulation practices are not an appropriate model for the PRB. 